\title{
Quando os dados oficiais revelam condições de trabalho: análise dos agravos à saúde de professores das escolas públicas do Município de São Paulo
}

Neide Sant'Anna Moura dos Santos

Dissertação apresentada ao Programa de Pós-Graduação em Saúde Pública da Faculdade de Saúde Pública da Universidade de São Paulo para obtenção do título de Mestre em Saúde Pública

Área de concentração:

Saúde Materno-Infantil

Linha de pesquisa:

Sociedade Contemporânea e Saúde Pública

Orientadora: Prof'. Dra. Maria da Penha Costa Vasconcellos

\section{São Paulo}

2004 


\section{AGRADECIMENTOS}

- Aos educadores das Coordenadorias da Lapa, Pirituba e Perus que, entendendo a importância da realização de pesquisas na área de Educação, gentilmente aceitaram contribuir com este estudo.

- À minha orientadora, Prof ${ }^{a}$. Dra. Maria da Penha Costa Vasconcellos, da Faculdade de Saúde Pública da USP, por acreditar que o tema apresentado se transformasse em pesquisa e esta na presente dissertação.

- Ao Prof. Ítalo Del Monte, Coordenador da Coordenadoria de Educação da Lapa por me disponibilizar o tempo necessário à realização desta pesquisa.

- Aos funcionários da Coordenadoria de Educação da Lapa, pela compreensão nos momentos finais da dissertação, quando nem sempre estive à frente das funções naquela Coordenadoria.

- À CPG da Faculdade de Saúde Pública da USP, pelo apoio à pesquisa na forma de concessão do prazo que me era necessário à conclusão deste trabalho.

- À Vanessa, pelo apoio incessante e pelos longos períodos de trabalho no computador.

- À Silvana, pela preciosa assessoria na análise estatística dos dados deste estudo e por me possibilitar os contrapontos necessários ao aprimoramento do trabalho.

- Aos que me apoiaram e contribuiram de modo direto e indireto para a realização desta pesquisa.

- Aos meus filhos, Andrea e Adriano, com meu pedido de desculpas por lhes ter roubado tanto tempo de convivência.

- Ao meu marido Fernando, pelo apoio incondicional, pelo carinho e pela vida em comum. 


\section{RESUMO}

Santos NSM. Quando os dados oficiais revelam condições de trabalho: análise dos agravos à saúde de professores das escolas públicas do Município de São Paulo. São Paulo; 2004. [Dissertação de mestrado - Faculdade de Saúde Pública da Universidade de São Paulo].

Objetivo.Uma vez que o processo saúde doença é determinado socialmente e que formas de trabalhar e de viver geram potenciais de beneficios e de riscos que se expressam na saúde, realizou-se este estudo com o objetivo de descrever e analisar as condições de trabalho dos professores, identificando-se as condições favoráveis e desfavoráveis do trabalho docente e sua repercussão na vida e no processo saúdedoença. Metodologia. A pesquisa, de caráter exploratório, envolveu 42 professores 11 readaptados e 31 em exercício - incluindo três estágios: a) fase exploratória para identificação da percepção da população de estudo quanto aos fenômenos saúde/trabalho no próprio contexto; b) aplicação de questionário possibilitando mensuração dos níveis de satisfação e para identificação dos aspectos do trabalho que provocam ansiedade, desgaste, estresse e podem levar à expropriação da saúde; c) análise ergonômica do trabalho buscando caracterizar as manifestações de aspectos do trabalho sobre a vida dos professores e verificar quais desses aspectos interferem na satisfação e na saúde. Resultados. Considerando os professores readaptados como representantes dos eventuais indicadores de agravos à saúde do professor, estes estudos revelaram que: 1) o tempo prolongado de exercício no magistério, nas condições e na forma em que hoje é realizado o trabalho docente, e o déficit na formação profissional, em relação às demandas do ensino, constituem fatores significativos de agravo à saúde do professor; 2) o número excessivo de alunos em classe e a insuficiência da remuneração, pela intensidade de freqüência com que apareceram na pesquisa, podem ser classificados entre os maiores indicadores de agravos ao bem-estar e à saúde; 3) as mudanças de políticas e propostas educacionais elaboradas à margem do magistério, a opinião pública depreciativa da tarefa docente, o baixo nível de realização profissional, as jornadas extenuantes, a transferência de responsabilidades da comunidade social e das famílias para a escola, tornam o trabalho cansativo e desgastante e interferem na vida pessoal, no bem-estar e na saúde do professor. Conclusão. Os resultados deste estudo evidenciam que as categorias de sofrimento no trabalho mantêm relação com a frustração das necessidades humanas e com a falta de realização no trabalho; a análise mostra que o desgaste e o estresse se revelam na insatisfação com a remuneração, no trabalho com classes numerosas, nas jornadas extenuantes, no acúmulo de responsabilidades transferidas à escola, na desvalorização do magistério, no conflito que se expressa nas dificuldades para levar o aluno a aprender. Pode-se dizer que os professores de ensino básico estão sujeitos a condições de trabalho que os expõem a cargas que ao longo do tempo podem levar a um desgaste de suas capacidades vitais.

Descritores: Saúde Ocupacional. Risco Ocupacional. Professores. Escola Pública. 


\section{SUMMARY}

Santos NSM. Quando os dados oficiais revelam condições de trabalho: análise dos agravos à saúde de professores das escolas públicas do Município de São Paulo. [When oficials informations shows work's conditions: teacher's health problems studies of a public school in São Paulo country]. São Paulo (BR); 2004. [M.Sc. dissertation - Faculdade de Saúde Pública da Universidade de São Paulo, Brazil].

Objective: Since the health-disease process is socially determined and work and life style bring potential benefits and risks which are reflected in health, this study were carried out in order to describe and analyze the work conditions of teachers, identifying favorable and unfavorable conditions and their impact in teachers life and health-disease process. Methods. The exploratory research included 42 teachers - 11 readjusted and 31 working teachers - and 3 stages: a) exploratory phase of identification of study group perception of health/work phenomena in their context; b) filling in questionnaire in order to measure the level of satisfaction and to identify job aspects that trigger anxiety, exhaustion, stress and may undermine health; c) ergonomics analysis aiming characterize the outcomes of the work conditions and to establish which of them affect satisfaction and health. Results. Considering readjusted teachers as a representative group of possible health problems among teachers, this study showed that: 1) the long term teaching activity, under the actual conditions, and the deficit in professional development in relation to the educational demands are important factors in health problems among teachers; 2) the excessive number of students in the classroom and the low income, both frequently reported, may be considered as the most important factors related to welfare of teachers and their health problems; 3 ) the political changes and educational proposals adopted disregarding the teaching profession, the prejudicial public opinion of teacher duty, the low level of job satisfaction, the exhausting working routine, the shouldering responsibilities of social community and families by the schools, make the work exhausting and let it interfere in the personal life, the welfare and the health of teachers. Conclusions. The results demonstrate that levels of suffering are related to human needs which are not fulfilled and to lack of job satisfaction; the analysis show that the overwork and stress are reflected in the dissatisfaction with the income, the overcrowded classrooms, exhausting working routine, growing responsibilities of the school, depreciation of teaching profession, and in the conflict arose from the difficulties of making the students learn. We may say that teachers of elementary education work under such conditions that make them shoulder a burden which, over the time, lead them to health impairment.

Descriptors: Occupational Health. Occupational Risk. Teachers. Public School. 


\section{ÍNDICE}

Pg.

1 - INTRODUÇÃO

2 - FUNDAMENTAÇÃO TEÓRICA ………….................................... 14

2.1 - OS DESAFIOS DO TRABALHO EDUCACIONAL ………………... 14

2.2 - O TRABALHO EDUCATIVO NO ÂMBITO MUNICIPAL ............... 29

2.2.1 - A escola pública municipal .................................................... 34

2.2.1.1 - O contexto da ação educativa ........................................ 36

2.2.1.2 - O ambiente da Escola Pública Municipal ......................... 40

2.2.2 - O professor de Educação Básica ............................................. 43

2.2.3 - O trabalho docente: satisfação e saúde ................................... 48

2.2.3.1 - Indicadores do mal estar docente .................................... 53

2.2.3.2 - O sofrimento do professor ……………………….......... 54

2.2.3.3 - Esgotamento profissional ............................................... 61

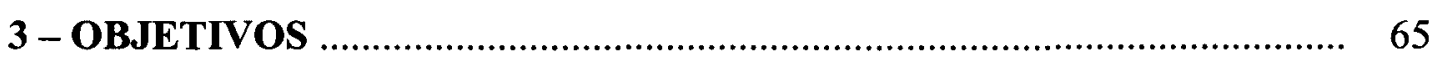

3.1 - OBJETIVO GERAL ……………......................................... 65

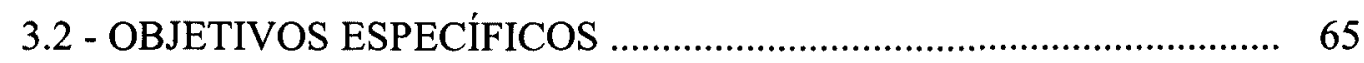

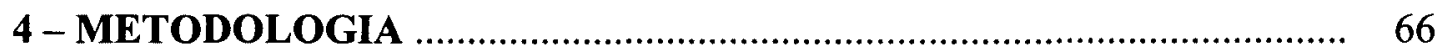

4.1 - DELINEAMENTO DA PESQUISA ……………………………...... 66

4.2 - COMPOSIÇÃO DO GRUPO DO ESTUDO ...................................... 72

4.3 - A COLETA DE DADOS ………………………………………......... 74 


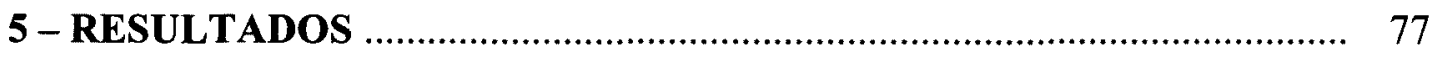

5.1 - SÍNTESE DOS RESULTADOS ……………………………........ 89

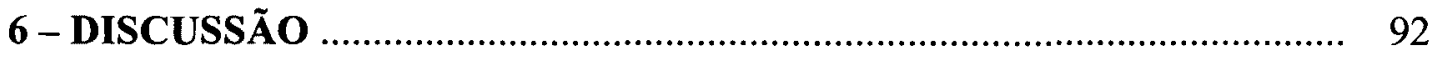

6.1 - DADOS AMOSTRAIS ................................................................ 92

6.2 - O PROCESSO DE TRABALHO …………………………………... 100

6.3 - CONDIÇÕES DE TRABALHO …………………….................... 105

6.4 - O AMBIENTE ESCOLAR …………………………..................... 110

6.5 - SATISFAÇÃO E INSATISFAÇÃO NO TRABALHO ......................... 114

6.6 - O SOFRIMENTO INSTITUCIONAL ……………………………... 125

7 - CONCLUSÃO

8 - CONSIDERAÇÕES FINAIS ............................................................... 136

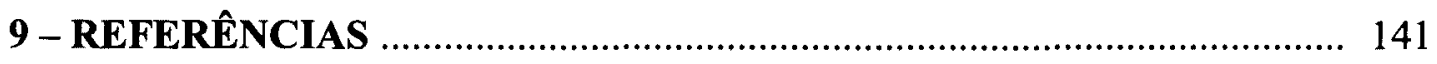

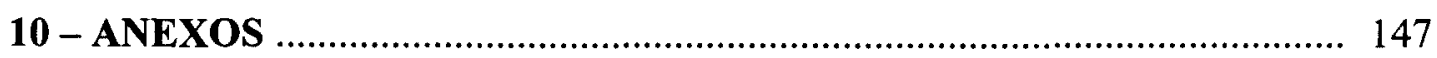




\section{LISTA DE QUADROS E TABELAS}

Quadro 1 - Distribuição do número e porcentagem de especialistas readaptados na Secretaria da Educação do Município de São Paulo

Quadro 2 - Distribuição do número e porcentagem de professores titulares readaptados na Secretaria da Educação do Município de São Paulo

Quadro 3 - Distribuição do número e porcentagem de professores adjuntos readaptados na Secretaria da Educação do Município de São Paulo

Quadro 4- Distribuição do número e porcentagem de profissionais readaptados pertencentes a outros quadros

Quadro 5 - A educação municipal em números

Quadro 6 - Total de servidores da Secretaria Municipal de Educação de São Paulo

Tabela 1 - Distribuição dos professores entrevistados em relação ao sexo

Tabela 2 - Distribuição dos professores entrevistados em relação à idade

Tabela 3 - Distribuição dos professores entrevistados em relação ao estado civil

Tabela 4 - Distribuição dos professores entrevistados em relação à escolaridade 
Tabela 5 - Distribuição dos professores entrevistados em relação ao nível de ensino em que atuam ou atuavam

Tabela 6 - Distribuição dos professores entrevistados em relação ao número de alunos em classe de trabalho

Tabela 7 - Distribuição dos professores entrevistados em relação à jornada semanal de trabalho

Tabela 8 - Distribuição dos professores entrevistados em relação à autonomia no trabalho

Tabela 9 - Distribuição dos professores entrevistados em relação ao ambiente de trabalho

Tabela 10 - Distribuição dos professores entrevistados em relação ao desgaste pelo número excessivo de alunos por classe

Tabela 11 - Distribuição dos professores entrevistados em relação ao trabalho repetitivo

Tabela 12 - Distribuição dos professores entrevistados em relação ao trabalho cansativo

Tabela 13 - Distribuição dos professores entrevistados em relação ao fato de mudanças freqüentes e desvalorização profissional interferirem na motivação para o trabalho

Tabela 14- Distribuição dos professores entrevistados em relação à concordância com o fato de o professor vitimado ser responsável pelo fracasso dos alunos

Tabela 15 - Distribuição dos professores entrevistados em relação ao fato de baixa realização no trabalho e não atingir objetivos propostos interferirem em sua saúde e bem-estar

Tabela 16 - Distribuição dos professores entrevistados em relação 
ao fato de fatores o rganizacionais do ambiente de trabalho interferirem em sua vida pessoal e saúde ..................
Distribuição dos professores entrevistados em relação

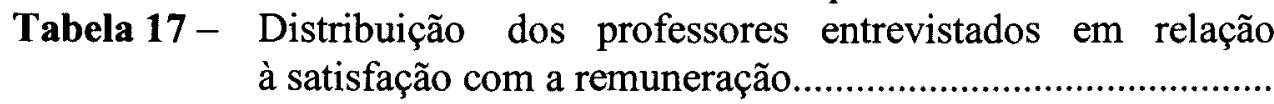

Tabela 18 - Distribuição dos professores entrevistados em relação à satisfação no desempenho de suas funções atuais

Tabela 19 - Distribuição dos professores entrevistados em relação à concordância com o fato de a sociedade simplificar os males da escola pública e responsabilizá-los pelo fracasso 


\section{INTRODUÇÃO}

A inserção profissional como Supervisora Escolar junto à Secretaria da Educação do Município de São Paulo, no exercício de acompanhamento e supervisão do trabalho educativo, tem nos proporcionado a oportunidade de observar o crescimento do número de professores que se afastam da atividade docente por problemas de saúde. Há algum tempo vimos observando, na atuação dos professores, de um modo geral, a tendência a um alto grau de insatisfação com o próprio trabalho. Independentemente do status social da instituição e dos diferentes graus de ensino, percebe-se uma espécie de frustração crônica que vai se acentuando com o passar do tempo e chega a se manifestar, em alguns casos, no desejo de o educador se aposentar, mesmo estando longe o tempo real de sua aposentadoria. Há casos de professores que pensam até mesmo em mudar de profissão.

Ressentem-se dos salários injustos, das condições precárias de trabalho, das jornadas extenuantes, das obrigações burocráticas distantes da verdadeira tarefa educativa. Alegam que as mudanças conjunturais praticamente inviabilizam os objetivos do trabalho docente, porquanto esses parecem que já não correspondem ao contexto atual. Ao mesmo tempo, insistem em que os processos de transformação social os obrigam a, rapidamente, redefinir papéis, mudar a prática, redimensionar projetos, o que lhes causa mal-estar e os faz sentirem-se exauridos.

O problema se evidencia, no entanto, quando esse sentimento de insatisfação invade de tal forma a relação com o trabalho que este assume a função de um fardo incapaz de proporcionar qualquer prazer. 
No acompanhamento da atividade docente temos observado que existe, no trabalho do professor, um sentido cuja pertinência intrínseca à experiência humana deveria ser capaz de proporcionar a esse profissional um grau de satisfação que pudesse sustentar o desejo de se manter nessa função, apesar das vicissitudes pelas quais passa em seu cotidiano. Mas, se a frustração toma quase todo o lugar da satisfação, algo na relação do educador com o seu trabalho está fora de lugar. Ou, mais propriamente, algo nas condições de trabalho do professor está em desordem.

Discorrer sobre a saúde dos professores implica, em primeiro lugar, abordar um tema de relevância social que precisa ter discutidos os caminhos que levem à maturidade deste campo do conhecimento, o das relações saúde/doença e trabalho. Pode-se dizer que a abordagem desse tema encontra amparo, também, em nossas leituras do Diário Oficial do Município, nas quais temos observado, ao longo do tempo, que o número de licenças médicas do pessoal da Secretaria de Educação supera o de todas as demais Secretarias juntas.

A par dessa constatação, vimos nos surpreendendo com o grande e crescente número de professores readaptados no quadro do magistério da Secretaria de Educação do Município de São Paulo. Cabe esclarecer que professores readaptados são os acometidos por enfermidades, com Laudo Médico definitivo ou temporário que os impossibilita de retornar às atividades normais de sala de aula. Permanecem trabalhando nas Escolas, com restrições de atividades, exercendo funções compatíveis com o seu estado de saúde.

Dever-se-ia dizer que é preocupante o fato de que uma escola, com quadro de vinte professores em atividade, chega a ter de quatro a cinco professores 
readaptados, instalados desconfortavelmente nas Secretarias da Unidade, local onde, em geral, exercem suas novas funções.

Como resultado desse quadro, verificamos que as escolas vêm funcionando com módulos esvaziados: pelas readaptações, que retiram o professor da sala de aula; pelas licenças médicas que, da mesma forma, impedem os professores de trabalhar.

Se não se constata, ainda, um quadro de abandono da atividade docente, é lícito supor que as condições de saúde podem, perigosamente, estar colocando os professores à porta de saída das escolas.

O fato é que não se pode correr o risco de um esvaziamento das salas de aula por não se cuidar direito dos profissionais responsáveis pelo ensino, justamente quando está mais que constituída e disseminada a importância crucial da educação para o desenvolvimento não apenas individual, mas também para mudanças no nível de desenvolvimento do país.

Educação faz parte da base de sustentação de uma sociedade, juntamente com trabalho e saúde, e não pode ser relegada a segundo plano, não só pelo que significa a Educação, mas por direito de saúde e bem estar comum a todos.

A nosso ver, estamos diante de um problema que promete ser bem mais amplo: as enfermidades dos professores atingem, de forma diversa, mas não menos prejudicial, os usuários do sistema educativo - os alunos. Por duas razões, então, precisa ser revisto. O que deve e se pretende fazer é um esforço para investigar as relações, como está organizado e os modos como se realiza o trabalho docente, como forma de identificar o universo das significações construídas em torno desse 
trabalho, compreendendo-se que, pelas diferentes relações do indivíduo com o trabalho, sua saúde pode ser implicada no mais alto nível.

Segundo a Organização Mundial de Saúde (OMS), "a saúde é um estado de completo bem-estar fisico, mental e social e não consiste, somente, em uma ausência de doença ou enfermidade".

A fim de progredir, com base nessa noção de saúde, DEJOURS (1993) faz críticas. Compreende que, se, intuitivamente, cada pessoa tem uma idéia do que é saúde, ou do que significa estado de completo bem-estar, é difícil e provavelmente impossível de se lhe dar uma definição. Indo além, acha que se pode mesmo afirmar que este estado não existe. Seria, então, preferível considerar o completo bem-estar mais como um ideal do que uma realidade. Nesta perspectiva, a saúde não seria um estado, mas um objetivo. Então, quando a realidade do trabalho se opõe ao desejo do trabalhador, colocando face a face os projetos de cada um e a organização do trabalho que limita a realização desses projetos, instala-se o conflito.

Assim, quando o trabalho pode ser livremente escolhido e quando a organização do trabalho é suficientemente flexível para que o trabalhador possa organizá-lo e adaptá-lo aos seus desejos, às necessidades do seu corpo, às variações do seu estado de espírito, pode-se transformar um trabalho que traz fadiga em um trabalho equilibrado e, dessa forma, diminuir os impactos negativos sobre a saúde e bem-estar.

As abordagens sobre saúde e doença, contudo, denotam que esses temas trazem uma carga histórica, cultural, política e ideológica que não pode ser contida apenas em fórmulas numéricas ou em dados estatísticos. A rigor, esse tipo de investigação deve contemplar características básicas do grupo de estudo, o que 
implica considerar a condição social, a organização e as relações com o trabalho, com suas crenças, valores e significados.

Discutir a relação trabalho-saúde do professor da escola municipal, ao contrário de macular a Administração Pública, a dignifica, devendo esta discussão ser entendida como passo importante, que abre perspectivas para minimizar problemas. Nesse contexto é preciso compreender e reconhecer o professor que adoece não somente pelo diagnóstico que carrega, mas também compreender o significado construído e sustentado pelo adoecido, a partir das contradições e conflitos relacionais vivenciados socialmente no cotidiano da Escola.

Diferentemente das outras, cujas conseqüências lesivas do trabalho são mais explícitas e recaem, muitas vezes, diretamente sobre o corpo do trabalhador, as doenças contemporâneas são sutis, menos físicas, incidem mais sobre os sistemas orgânicos de relação, a ponto de passarem despercebidas até pelos próprios vitimados. Nas atuais circunstâncias, a relação linear e direta, expressa pelo princípio do nexo causal, perde sentido, apontando para a causalidade complexa das doenças ocupacionais e a necessidade de novos paradigmas (RIBEIRO, 1998).

Em busca de compreender o nexo entre a saúde dos educadores e as condições de trabalho, elegemos o professor de Ensino Básico como tema da pesquisa, mormente os readaptados, visto que têm uma vinculação mais significativa com o problema a ser investigado.

Como Supervisora Escolar, ouvimos histórias de professores que relatam problemas em busca de ajuda para resolver ou esclarecer dúvidas que envolvem questões de saúde e trabalho. Nas inúmeras conversas mantidas, fomos 
constatando a necessidade de compreender que adoecer, para o professor, adquire uma dimensão de sofrimento que vai além do biológico.

A partir daí criamos a nossa própria agenda de formação continuada FUSARI (1995) e começamos a aprofundar estudos em busca de conhecimentos que nos permitissem analisar a inter-relação entre processo de trabalho docente e expropriação da saúde.

Verificamos que as imagens historicamente projetadas na docência continuam vigentes, mas, nos últimos anos, parece que não mais correspondem à realidade. Dever-se-ia dizer, como hipótese, que o professor não se sente preparado para os desafios que lhe são postos de maneira crescente; menos ainda, para reavaliar e modificar a própria prática diante de situações adversas.

A aprendizagem, hoje, não se faz numa relação bipolar: sujeito que ensina e sujeito que aprende. As políticas que estabeleciam a centralidade do professor, hierarquização de conhecimento, ritmo de desenvolvimento predeterminado a todos, desvalorização dos conhecimentos não escolares e rígidos mecanismos de avaliação não mais se sustentam. Contrapondo-se àquelas, a centralidade é do aluno. O papel do professor passa a ser o de estimulador e formulador de situações de aprendizagem.

Desse modo, no momento em que os modelos validados e consensualmente aceitos parecem não mais funcionar, instaura-se a crise do paradigma que leva ao aparecimento de um grande vazio e de um novo questionamento quanto à possibilidade de esses novos modelos, que hoje derrubam os anteriores, também poderem vir a ser, eles mesmos, questionados amanhã (NEVES, 2002). 
Atuar, então, em meio a esse contexto de mudanças leva a admitir que o trabalho do professor se processa em clima de instabilidade, uma vez que não se trata só e meramente da substituição de verdades, de paradigmas, senão também e, principalmente, de como lidar com essa substituição.

Estamos num período caracterizado por grandes e rápidas transformações. A rapidez, a profundidade e a imprevisibilidade de algumas transformações recentes conferem, ao tempo presente, uma característica nova: a realidade parece ter tomado a frente sobre a teoria de uma forma a teorizar-se por si mesma. Vivemos, assim, uma condição complexa: um excesso de realidade que mal se distingue da auto-realização da teoria (SANTOS, 1996).

Para esse autor, o agravamento das crises globais acentua-se neste início de século, em todos os âmbitos das sociedades contemporâneas, levando o conjunto de nações a estabelecer princípios e diretrizes em relação à sustentabilidade do planeta. A interdependência e a fragilidade das economias emergentes, o esgotamento dos recursos renováveis e não renováveis, a exploração e perda da biodiversidade, os problemas gerados pela própria revolução científica e tecnológica, a crise dos valores éticos e, ainda, o crescente aumento da pobreza em nível mundial caracterizam este momento e reforçam a necessidade de redefinição dos modelos e políticas de desenvolvimento vigentes.

Nas últimas décadas, a emergência da globalização acarretou profunda reestruturação produtiva (RIGOTTO, 1998). O mesmo processo exigiu transformações radicais no campo da educação, influenciando tanto a vida quanto a saúde dos profissionais que atuam nessa área. 
Analisando o cenário político, PLASTINO (2002) argumenta que o contexto global se caracteriza, no atual momento histórico, pelo fracasso das diversas modalidades recentes de organização social, entendendo por fracasso sua incapacidade de organizar a sociedade em torno dos objetivos de solidariedade, igualdade, liberdade.

Fracasso dos regimes do denominado socialismo real, transformados em ditaduras, burocráticas e ineficientes. Fracasso da denominada social-democracia, caracterizado pelo abandono dos objetivos solidários e das políticas de bem-estar social. Este segundo fracasso se evidencia nos indicadores de desemprego, marginalização e deterioração dos serviços públicos de Saúde e Educação. De acordo com PLASTINO, o cenário social e econômico contemporâneo indica que, no modelo de sociedade neoliberal, não há lugar para todos, de modo que o progresso tecnológico tem, como contrapartida, a marginalização de setores cada vez mais significativos e a insegurança de todos, o que coloca em questão o papel da escola.

Hoje, os educadores são desafiados a entender como sobrevive, em que e como trabalha e como se educa a multidão de excluídos da economia globalizada. A realidade crescente do desemprego e a precarização do trabalho assalariado constituem um quadro sócio-econômico cultural e existencial de milhões de pessoas de que os clássicos conceitos de economia e mercado formal não dão conta. Assim, emergem do contexto das políticas neoliberais de ajuste aos processos de globalização, novos desafios, contradições e conflitos, mormente no âmbito da Educação Básica e do Ensino Técnico-Profissional.

Desse modo, no contexto de mudanças que estão ocorrendo na política social, econômica e no mundo do trabalho, o papel da escola volta a ser questionado. 
De um lado, a presença de uma cultura de jovens que contesta os valores centrais da sociedade do trabalho tradicional. De outro, a de seus pais, com valores do velho conceito de trabalho que ainda acredita no poder da escola como garantia de empregabilidade.

A realidade educativa é, então, atravessada por essas questões, e os professores, nesse meio, acham-se ressentidos ante a produção de uma ética do trabalho moderno que se contrapõe a uma outra, que luta ainda pela sobrevivência. Perante essa realidade, não sabem ao certo qual o papel da escola, nem o que e como ensinar.

Segundo ESTEVE (1999), também o sistema escolar se sente incapaz de reagir com a devida rapidez a todas essas demandas. Isso faz com que os profissionais da educação se tornem alvo das crescentes dificuldades e da crítica social.

Num constante processo de ampliação, o conceito de escolaridade, hoje, incorpora características que vão além da habilidade de ler e escrever, por exemplo. O alfabetizado deve estar apto ao manejo dos mecanismos de informação, ter domínio de habilidades técnicas que lhe permitam participar da vida cotidiana da sociedade e ter acesso ao cada vez mais restrito e seletivo mercado de trabalho. Isso implica, em primeira instância, saber valer-se dos recursos das novas tecnologias. MELLO (1994) enfatiza que a preparação da sociedade para incorporar os avanços tecnológicos, de modo a utilizá-los para melhorar a qualidade de vida, é condição para evitar a ação de elementos de seletividade e desigualdade social.

Mas, nesse contexto de crise estrutural, com a configuração da geografia humana dividida em blocos econômicos, com poder e realidades 
assimétricas, surgem novas categorias de organização do trabalho e modelos gerenciais que podem intervir na base estruturante das condições de funcionamento da escola.

Como assinala ARROYO (2000), os interesses neoliberais, hoje, querem colocar, no centro da ação educativa escolar, a comunidade, as famílias, as organizações sociais, a sociedade dos empresários, a mídia e os amigos da escola, correndo o risco de descaracterizar o núcleo constitutivo da ação educativa, tirando o foco da dimensão pessoal, do diálogo e convívio de gerações, do saber fazer, da arte dos professores.

Ao exame desse texto se percebe que o autor concebe a participação da comunidade como importante para que educandos e educadores percebam a proximidade entre os espaços familiares, comunitários e escolares, entre o saber dos currículos e os saberes sociais, mas que não se pode substituir a gestão participativa pelo cerne da relação educativa, sob pena de a arte de educar se tornar descaracterizada.

De outro lado, essas questões trazem aos educadores e às instituições onde trabalham o desafio de atenderem às demandas mais diversificadas, uma vez que, no processo de globalização, as desigualdades sociais, econômicas e culturais são reconfiguradas de acordo com regras propostas pelas forças que as sujeitam.

Como se vê, a própria situação sugere que a falta de uma estrutura de sustentação às novas demandas e a presença de fatores determinantes de insatisfação no trabalho desestabilizam o funcionamento da escola e geram inseguranças aos que nela trabalham. 
Ao mesmo tempo, as condições adversas a que vem sendo submetido o professor e a sobrecarga de atribuições impostas às Unidades Escolares geram, por sua vez, pressões que o levam ao desânimo, ao estresse e à fadiga.

A par das exigências educacionais, têm-se atribuído às escolas tarefas adicionais ocasionadas pelos novos arranjos das famílias dos alunos, pela inserção da mulher no mercado de trabalho, que, por isso não mais dispõe de tempo para cuidar dos filhos, pelos encargos sociais de competência administrativa, pela promoção e prevenção da saúde das comunidades locais, levando os educadores a assumirem funções para as quais não receberam formação específica, impossibilitando-os de agir com competência.

Ao mesmo tempo, os Programas e Projetos Sociais implementados pela Administração Municipal, nos quais a escola é responsabilizada por divulgação, contato com as famílias, preenchimento de fichas, cadastros, relatórios, controle de freqüências, distribuição de leite, uniforme, material escolar, transporte de alunos, avolumam sobremaneira o rol de atribuições conferidas aos professores.

Desestabilizações e conflitos que a partir daí se instalam produzem tensão que refletem também na relação professor/aluno, comprometem o trabalho e expõem os educadores a condições acima dos limites de tolerância, levando-os a reagir às agressões do contexto, o que termina por afetar-lhes a saúde.

Várias hipóteses foram levantadas para explicar o aumento do número de professores licenciados e readaptados, em razão de doenças advindas do trabalho, no âmbito da Secretaria Municipal de Educação mas, ao que parece, não conseguiram ir além do campo das hipóteses. Pode-se notar que o número de readaptações tem crescido de forma nunca antes imaginada, mormente se comparado 
com o das demais áreas da administração pública, sem que medidas tenham sido adotadas com o fim de reverter ou, pelo menos, minimizar esse quadro. Configurase, então, a necessidade de investigações que consigam detectar os indicadores dessas ocorrências e de avaliações contínuas dos agentes que desencadeiam sintomas, lesões e doenças, a fim de que se possa avançar em busca de equilíbrio na relação entre capacidade laborativa e demandas do trabalho.

A presente investigação incide nos estudos sobre o ambiente de trabalho, em especial na influência da estrutura organizacional sobre a saúde e bemestar dos professores, mormente dos que perderam a capacidade funcional para o trabalho docente.

Como já exposto, a saúde não é um estado, mas um objetivo que se remaneja sem cessar. Não é alguma coisa que se tem ou não se tem, mas que se tenta conquistar e se defende, como a liberdade.

$\mathrm{Na}$ aceitação dessa premissa, compreende-se que a saúde não é apenas responsabilidade dos outros, de uma instituição, dos médicos ou do Estado. É, antes de mais nada, responsabilidade de todos e de cada um. Nessa perspectiva, justificase, então, uma pausa de percurso para pensar e discutir o trabalho enquanto atividade docente. Uma discussão que dê suporte à composição de um diagnóstico que possibilite perceber circunstâncias que podem causar agravos à saúde dos professores, no caso, os da Rede Pública do Município de São Paulo.

Essa ordem de idéias corrobora a necessidade de se identificarem os elementos envolvidos nessa problemática, até como forma de subsidiar a ação supervisora, visto que esta nem sempre detém elementos de argumentação convincentes, quando na intervenção de conflitos que se estabelecem entre 
professores faltosos e pais de alunos, entre readaptados e equipe administrativa, entre readaptados e professores em exercício.

Desconhecendo as circunstâncias, muitas vezes, adota medidas à luz do estritamente contido em lei, o que, do ponto de vista da equanimidade, nem sempre é correto. Então, na via de raciocínio que se propõe neste estudo, esse tipo de pesquisa pode representar um desafio ético à própria pesquisadora, uma vez que os fenômenos saúde-doença aqui são estudados no contexto econômico, político e organizacional do trabalho educativo, e não apenas como fenômeno biológico de âmbito individual, portanto, nos limites da área de atuação da supervisão escolar.

Justifica-se o presente estudo pela contribuição que dele se poderá obter para o entendimento do comportamento humano no ambiente de trabalho; pela iniciativa de diagnóstico das condições mínimas necessárias ao desempenho funcional dos professores do Ensino Básico e pela contribuição de dados para uma análise mais criteriosa sobre as questões de saúde, doença e trabalho. 


\section{FUNDAMENTAÇÃO TEÓRICA}

\subsection{OS DESAFIOS DO TRABALHO EDUCACIONAL}

Tantos e tantos escritos discutem a educação, a crise da educação, os métodos para educar, mas poucos discutem o que faz o educador. De fato, no momento atual, a educação se apresenta, a um só tempo, obrigatória e problemática: O que ensinar? Para que? Para quem? Mas, se é dificil pensar a educação sem uma filosofia educacional, sem uma teoria pedagógica consistente, sem uma política clara, também é inócuo pensar a educação na ausência do que faz o educador. No entanto, pouco se lê sobre o educador e a educação.

Sabe-se que o aluno não entra na escola só para receber e dominar conteúdos, mas para ser educado como um todo. De fato, os educadores não raro discutem modos de agir, maneiras, princípios éticos, morais, de religião, literatura. Desse modo, com base apenas no senso comum, é difícil dizer onde começa e onde termina a educação.

Pode-se considerar que começa em qualquer lugar e em todos os lugares. Que nunca termina. Que nunca é completa. Acompanha cada homem, cada mulher, desde o principio e, nesse sentido, pode-se dizer que educação é incomensurável.

$\mathrm{Na}$ escola, contudo, a educação aparece como uma tarefa objetiva, finita, mensurável. Tem lugar, faz-se em localidade própria, funciona com horários, tem dono, autor, começo, fim, critérios, mede-se, avalia-se. Do mesmo modo, na 
escola, o aluno tem alguém responsável pela sua educação, com objetivos prétraçados, metas, programas seqüenciais em que cada habilidade é necessária para a aquisição da próxima, resultados definidos, porcentagens.

O professor, por sua vez, faz cursos, concursos, define metodologias, estabelece critérios de avaliação.

Agora, quando as diretrizes educacionais dispõem que o aluno deve dominar princípios éticos e morais capazes de transformá-lo em cidadão; que é preciso trazer a realidade concreta de cada aluno para a sala de aula; que não basta memorizar normas e datas, mas que é preciso desenvolver capacidade de crítica, sentimento de justiça, ser criativo, percebe-se que retorna a dificuldade para medir, diferenciar, definir a educação.

Então, como pode o professor dizer que faz uma tarefa que não se define? Que não tem começo nem fim? Que sequer se sabe claramente o que é?

Educar é o ato mágico de realizar uma síntese entre o passado e o futuro, de ensinar o que foi para inventar e ressignificar o que será (CODO, 1999). Para tanto, na escola, existe um profissional cuja obrigação é a de reconstruir o passado e o futuro ligados à vida: o professor.

O professor que transforma o outro através do outro mesmo, sem mediação. O seu produto é o aluno educado, formado. Não importa, para ele, se o aluno sabe repetir nomes de países e capitais. Importa é o que muda no aluno. Importa é que agora sabe ler e escrever, consultar, raciocinar. Depois de cada aula, o professor é outro; são outros os seus alunos.

Em uma palavra, para o educador, o produto é o outro, o meio não é o trabalho em si, é ele mesmo. Na escola, o processo de trabalho se inicia e se 
completa em uma relação estritamente social, permeado e carregado de História. E essa relação direta e imediata com o outro é, necessariamente, permeada de afeto. Afeto como componente tácito do trabalho docente.

Em verdade, todo trabalho envolve algum investimento afetivo, quer seja na relação com o outro, quer mesmo na relação com o produto. Mas, no caso do professor, a relação afetiva é obrigatória para o próprio exercício laboral. É um prérequisito.

Então, para que o trabalho seja efetivo, para que atinja seus objetivos, a relação afetiva necessariamente tem que ser estabelecida (CODO, 1999), o que nem sempre acontece.

Atualmente, estamos em presença de um descompasso. Aspectos estruturantes da identidade profissional dos educadores, como sua formação, o papel social da educação e das escolas, estão sendo questionados. Não se sabe, ao certo, como preparar os educadores. Não se sabe qual o papel da educação e da instituição escolar na situação atual, caracterizada pela reestruturação do sistema capitalista e as metamorfoses que dele advêm.

Esses fatores, de índole estrutural da sociedade, têm influência sobre diferentes aspectos da realidade do trabalho nas escolas e, por essa via, acabam tendo efeitos sobre a conflitiva relação estrutural que todo educador mantém com seu trabalho.

A atividade de educar, como já se viu, exige do educador o estabelecimento de um vínculo afetivo-emocional com o objeto do trabalho: o aluno. A realização desse afeto, contudo, é interditada na medida em que a influência do educador sobre o educando nunca se completa, instalando a possibilidade de perda 
do controle sobre o produto e, por essa via, de dúvidas sobre a sua competência profissional.

Esse conflito, que existe em tese, vem à tona em situações concretas, uma vez que é no cotidiano da sala de aula que os educadores põem à prova sua competência na condução do processo de ensino/aprendizagem. Nesse embate, o vínculo afetivo e emocional com os alunos, exigido pela atividade de ensinar, será, em maior ou menor medida, interditado pela realidade do trabalho.

O sofrimento psíquico pode resultar, então, desse jogo de interdições que a realidade do trabalho docente impõe à realização do afeto e emoção: fragmentação, técnicas, hierarquia, normas, objetividade. Como se vê, a organização taylorista associada à reestruturação da sociedade expulsaram o afeto das relações de trabalho. Mas é que o educador exerce um trabalho impossível de ser taylorizado, de se enquadrar em uma linha de montagem fordista. Exerce um trabalho que, ou leva em conta os vínculos afetivos com o aluno, com o produto, com as tarefas, ou simplesmente não se realiza.

Cabe esclarecer que a denúncia dessa crise e a concomitante defesa de condições efetivas de trabalho para o magistério aparecem com freqüência nos textos que discorrem sobre professores. Essa questão está entre os temas consensuais de debates e continua sendo um problema bastante presente nas discussões atuais, mas advém de contexto remoto.

No final dos anos quarenta, com o fim da ditadura Vargas, até o movimento civil-militar de 1964, o campo da cultura, das artes e da educação protagonizou um intenso debate, inscrito numa alternativa de sociedade democrática e cidadania efetivas. 
O governo instalado em 1964, no entanto, interrompeu o processo, que é retomado na década de oitenta, na elaboração da Constituinte e da nova Lei de Diretrizes e Bases da Educação Nacional (LDB).

A consolidação do bloco conservador no poder articula, então, um projeto educacional, da pré-escola à pós-graduação, ajustado à nova era de mercado. Reedita, sob uma perspectiva desintegradora, o economicismo, o tecnicismo e o produtivismo das reformas educativas patrocinadas pelo regime governamental da época. Um projeto alheio aos anseios históricos da sociedade brasileira, fundado nas diretrizes político- administrativas e pedagógicas dos organismos internacionais, mormente do Banco Mundial. Este desloca sua atuação centrada no binômio segurança/desenvolvimento para o de educação como alívio da pobreza (FRIGOTTO, 2001).

Segundo esse mesmo autor, é neste contexto, inclusive, que surge a economia da educação como campo disciplinar específico, cujo eixo central associa educação com o desenvolvimento econômico, o emprego, a mobilidade e a ascensão social.

Nessa linha, GADOTTI (1993) tece críticas ao sistema de ensino brasileiro inserido no contexto de uma sociedade capitalista dependente, e analisa a situação da educação nacional no início dos anos 80. De acordo com GADOTTI, a deterioração da educação é conseqüência de uma política orientada pela tecnoburocracia a serviço do estado burguês, que não quer investir em qualidade, já que o lucro - a sua finalidade - provém da quantidade e não da qualidade. Argumenta que o Estado transformou a educação em mercadoria, sujeita à lei do capital, da oferta e da procura. Incentivou a privatização do ensino e da cultura porque não interessa ao 
capital investir em educação através do Estado, visto que pode utilizar os eventuais recursos destinados à educação para empreendimentos de retorno mais imediato.

Em assentimento a essas críticas, NÓVOA (1996) infere que a racionalização e a privatização do ensino são aspectos de uma política que olha a educação segundo uma lógica economicista e define a profissão docente segundo critérios técnicos.

Decorrente dessa lógica, a expansão da rede de ensino, no Brasil, evidenciada pelo aumento do número de vagas e de matrículas nas escolas, não foi acompanhada de investimentos proporcionais por parte do governo. Houve, conseqüentemente, demanda de um número cada vez maior de professores para uma população escolar crescente. Essa nova exigência foi, de certa forma, atendida pela expansão do ensino superior privado e da criação indiscriminada de cursos de licenciatura em faculdades isoladas, bem como pela permissão do exercício profissional por pessoas não-habilitadas, os chamados professores leigos.

CANDAU (1987) analisa de diferentes ângulos a situação do magistério no país, mas identifica a desvalorização e descaracterização como o eixo central da problemática do magistério como profissão. Argumenta que esse processo de desvalorização e descentralização se expressa na progressiva queda dos salários reais dos professores, responsável pela sobrecarga de suas atividades, e conseqüente queda da qualidade de ensino, fato que acarreta aos profissionais, além do esgotamento pelo excesso de trabalho, extrema frustração.

Parece acertado dizer que a organização social do trabalho na escola tem influência decisiva na ocorrência da descaracterização da atividade docente. CURY (1984) aponta que a organização social do trabalho dentro da escola, 
fragmentando o conteúdo e parcelarizando o processo de ensino, retirou do educador, em especial do professor, o controle sobre a totalidade de sua prática. Segundo o autor, por meio da divisão entre trabalho de execução e trabalho de concepção, o professor foi sendo paulatinamente esvaziado dos seus instrumentos: do conteúdo (saber), do método (saber fazer), restando-lhe agora, quando muito, uma técnica sem competência.

Na opinião de ARROYO (2000), a Lei de Diretrizes e Bases da Educação Nacional (LDB), $\mathrm{n}^{\circ} 5692 / 71$, descaracterizou a escola e os currículos de formação. As licenciaturas desfiguraram seus mestres. Os currículos gradeados e disciplinares empobreceram o conhecimento, a escola e os professores. Reduziram a escola a ensino, e os mestres a ensinantes.

Argumenta que, em suma, a Lei 5692/71 fragmentou a categoria, e a nova LDB de 1996 não conseguiu recuperar a unidade perdida, concluindo que essa fragmentação resultou do processo de "taylorização" a que a educação foi submetida nos anos anteriores. Infere que a organização burocrática do sistema de ensino e da escola e a fragmentação do trabalho pedagógico geraram uma escola onde a impressão que se tem é de que professores e especialistas de educação perdem dia-adia a sua autonomia e o seu espaço de ação.

$\mathrm{O}$ atual sistema educativo tem sofrido uma crise que ultrapassa as fronteiras nacionais (ESTEVE, 1999). Os motivos mais apontados para a crise enfatizam que a situação é resultado da proletarização ou do fato de a profissão ter passado a ser composta majoritariamente pelo elemento feminino (FERREIRA, 1998). 
ENGUITA (1991) defende que as dificuldades enfrentadas pelos professores, tais como "crise de identidade", "situação de mal-estar", "agudos conflitos em torno do seu estatuto social e ocupacional", estão relacionadas à posição intermediária que o magistério tem ocupado entre a proletarização e $\quad$ o profissionalismo.

No Brasil, NOVAES (1987) também remete a questão da desvalorização do magistério à proletarização do profissional. Relaciona a divisão técnica do trabalho docente à sua proletarização, e esta última, por sua vez, à desvalorização do magistério.

Em suma, a educação vem acumulando, ao longo de sua história, uma série de fracassos que deságuam, hoje, num quadro de total precariedade do ensino público, em todos os níveis. SILVA (1993) enfatiza que o problema reside na incapacidade de a escola abandonar suas práticas centenárias e virar do avesso sua organização interna para atender aos interesses das crianças e jovens que a buscam, o que parece não ser o caso, visto que o ensino e a aprendizagem não decorrem só e apenas das práticas escolares. Argumenta que centrar o problema do fracasso escolar na má formação dos professores parece ser puro reducionismo, no que há de concordar-se, tendo em vista que tal centralidade desconsidera as circunstâncias históricas que envolvem essa questão.

Argumenta SILVA (1993), ainda, que nos anos sessenta, o fracasso escolar era concebido como decorrência das características individuais de cada aluno. Nos anos setenta surge um enfoque de cunho institucional, segundo o qual um dos principais artífices do fenômeno passa a ser a escola. A partir da década de oitenta, a descentralização das ações da Secretaria da Educação representava o esforço pela 
melhoria da qualidade do ensino e redução do número de reprovações de alunos, demanda que parece não ter sido atingida, pelo que se pode deduzir do quadro que hoje se apresenta.

Cabe destacar que a acelerada mudança do contexto social em que se exerce o ensino apresenta, a cada dia, novas exigências. O sistema educacional, rapidamente massificado nas últimas décadas, ainda não dispõe de uma capacidade de reação para atender às novas demandas sociais. A rápida expansão do número de vagas não permite que a escola dê atenção individualizada aos alunos, nem cuide de recuperar defasagens do ensino, apenas para citar alguns dos aspectos da massificação. Segundo ESTEVE (1999), os professores encontram-se ante o desconserto e dificuldades de demandas mutantes e a contínua crítica social, por não chegarem a atender às novas exigências. Argumenta que, às vezes, o desconserto surge do paradoxo de que essa mesma sociedade, que exige novas responsabilidades dos professores, não lhes fornece os meios que eles reivindicam para cumpri-las. Outras vezes, da demanda de exigências opostas e contraditórias.

Pode-se dizer que a mudança social acelerada converteu o sistema educacional em uma realidade qualitativamente diferente da que se tinha há vinte anos, por exemplo: hoje, as escolas são superlotadas, funcionam com vários turnos diários, e com professores sobrecarregados pelo número excessivo de aulas que são obrigados a assumir.

De acordo com ESTEVE (1999), as transformações apontadas supõem um profundo e exigente desafio pessoal para os educadores que se propõem a responder às novas expectativas projetadas sobre eles, pois que já não existe o amparo do consenso social. Qualquer atitude do professor pode ser contestada, e 
haverá grupos e forças sociais dispostos a apoiar a contestação ao professor. Qualquer valor que se defenda em classe pode ser rebatido, não somente sob a perspectiva individual de um aluno, mas com o apoio de diferentes correntes de opinião que têm suas origens nos meios de comunicação de massa (SANTOS, 1996).

Segundo FRASER (1996), o equilíbrio entre o ambiente psicossocial do trabalho e os indivíduos é dinâmico e determinado por múltiplos fatores que interagem, fazendo com que as relações entre fatores psicossociais, satisfação no trabalho e saúde sejam complexas, multidirecionais e, às vezes, dificeis de serem identificadas. Essa situação é agravada pelo fato de que o professor se depara, muitas vezes, com a necessidade de desempenhar papéis contraditórios ao mesmo tempo.

RIGOTTO (1998) aponta reflexos que as novas formas de produção e de relações sociais têm sobre o mundo do trabalho. No caso do professor, aponta a exigência de um novo perfil, caracterizado por aquisição permanente de conhecimentos, polivalente, com iniciativa, criatividade, aumento do ritmo de trabalho, diminuição das pausas para descanso e aumento da carga de responsabilidades.

Nesse caso, a imagem que o professor tem de si está condicionada à exigência de posturas convencionais. Ocorre que, entre o ideal da função de professor - requerido tanto pelo sistema, como pelos alunos e pelo próprio aspirante à função de educador - e as condições que o mercado de trabalho impõe, perdura um espaço de tensão que ocasiona um nível de estresse elevado, pressionando para baixo e eficiência da atividade docente (TEVES, 1999). Segundo a autora, somam-se a isso as constantes transformações advindas dos avanços tecnológicos, que põem em risco 
de extinção a própria função educativa e agrava ainda mais a angústia desses profissionais.

Por outro lado, tendo em vista a necessidade de sobrevivência que se impõe não apenas ao professor do ensino público, mas também aos docentes de escolas privadas, tanto no que diz respeito à sua imagem de educador quanto no sentido de qualidade de vida, produz-se um esgotamento, verificado pelo número elevado de aulas que ministram para fazer frente ao orçamento familiar. Esse cansaço leva a um acentuado absenteísmo provocado pelo aumento de licenças de saúde, dentro de um quadro de doenças típicas de professores (ESTEVE, 1999).

O fenômeno é complexo para se fazerem afirmações taxativas, mas a hipótese da relação entre o aumento da tensão nos períodos de trabalho e as licenças médicas permanece validada pelos estudos realizados por ESTEVE (1999) sobre o absenteísmo, nos quais se constata serem maiores as ausências depois de períodos mais prolongados de trabalho. Esses estudos inferem que o número de licenças médicas está diretamente ligado à sobrecarga do trabalho docente.

Esses estudos parecem sugerir respostas às indagações: por que tantos professores se licenciam em razão de problemas de saúde? Por que muitos são levados a se readaptarem ao exercício de funções alheias ao magistério? O que leva à ocorrência prematura de incapacidade ao trabalho educativo? Que aspectos do trabalho na instituição escolar seriam desgastantes? Quais seriam os prejudiciais à saúde e ao bem-estar dos educadores e quais seriam motivadores de satisfação?

No contexto social, ESTEVE (1999) cita variáveis como: mudanças excessivamente rápidas das leis trabalhistas, mudanças de tarefas e funções, alterações na formação profissional, aumento das demandas de serviços de saúde e 
educação, perda de prestígio social, mudanças econômicas e administrativas. Mudanças funcionais, no que se refere ao papel, desenvolvimento da carreira, dificuldades institucionais, condições de trabalho e pouco respaldo profissional frente à valorização do trabalho influenciam os profissionais cujas funções exigem alta demanda emocional.

A falta de apoio no trabalho, de colegas, supervisores, direção ou administração, os conflitos com alunos e familiares são também fatores que aumentam a possibilidade de esgotamento.

Argumenta ESTEVE que essa situação de fadiga e insatisfações tem levado os profissionais do magistério a um absenteísmo excessivo e a um número muito grande de licenças médicas. Alguns chegam aos processos de restrição de funções e readaptações funcionais ${ }^{1}$.

As restrições de funções e readaptações decorrem da avaliação médica de incapacidade para o exercício do magistério. Os servidores assim enquadrados são afastados das funções de sala de aula e recebem um rol de atribuições compatíveis com o seu estado de saúde.

Para se ter uma idéia da dimensão do problema nas Escolas Públicas Municipais, segundo dados de $\operatorname{CONAE}^{2}$, a Secretaria da Educação do Município de São Paulo registrou, no ano de 2000 , um número de 2.173 servidores afastados das suas funções normais de trabalho, sem possibilidades de retorno, num universo de 46.825 funcionários, por questões de saúde. No ano de 2001, o número de servidores

\footnotetext{
' Professores readaptados ou com restrições de funções são professores acometidos por enfermidades, portadores de Laudo Médico, definitivo ou temporário, que os impossibilita de retornar às atividades normais de sala de aula. Permanecem nas Unidades Escolares, mas com restrições de funções. O Departamento Médico determina atribuições compatíveis com seu estado de saúde.

${ }^{2}$ CONAE - Coordenadoria dos Núcleos de Ação Educativa da Secretaria da Educação do Município de São Paulo, 2001.
} 
readaptados atingiu o montante de 2.418 , num total de 50.939 funcionários, dos quais 1.462 readaptados pertencem ao quadro do magistério.

As Coordenadorias Regionais de Educação da Lapa, Perus e Pirituba região escolhida para realização desta pesquisa -, que agrupam 107 escolas e 4.328 funcionários, dos quais $65 \%$ são docentes, registraram, no período de fevereiro a dezembro de 2001, uma quantidade significativa de 930 licenças médicas, dentro do quadro de 4.328 funcionários.

Atualmente, o trabalho dos professores tem sido alvo de análises e críticas devidas ao baixo desempenho apresentado pelos alunos. As condições de trabalho, formas de atuação, histórias de vida têm sido objeto de estudos e pesquisas (NÓVOA, 1992). Porém, as questões relacionadas especificamente à saúde deste profissional têm sido pouco estudadas.

As relações entre trabalho e saúde foram abordadas com maior profundidade a partir da Encíclica Pacem in Terris, em 1963, pelo Papa João XXIII, que pregava o direito às condições adequadas ao trabalho, que não fossem lesivas à saúde.

No Brasil, a $2^{\mathrm{a}}$ Conferência Nacional de Saúde do Trabalhador, realizada em Brasília, em 1994, ao criar as Comissões de Saúde do Trabalhador, determinou que estas deveriam não só evitar acidentes, mas também garantir a saúde dos trabalhadores, uma vez que doenças profissionais são as que resultam do exercício do trabalho, inerentes a determinadas ações profissionais.

Pesquisa realizada com professores municipais por TELXEIRA (1999) revelou que $60 \%$ apresentavam ou já haviam apresentado algum problema vocal; $67 \%$ nunca receberam orientação nesse sentido. Constatou-se, ainda, que $68 \%$ das 
alterações possuíam um início insidioso e apenas $38 \%$ dos entrevistados procuraram tratamento.

Cabe, pois, concluir que as enfermidades vocais possuem importância epidemiológica, tanto pelo número de pessoas que atinge, quanto por seu impacto econômico e ocupacional. Esses estudos demonstram, ainda, que a origem da maioria dos distúrbios vocais está relacionada a uma ação conjunta de diversos fatores, em estrita relação com o ambiente e a organização do trabalho.

Dados do Departamento de Saúde do Trabalhador Municipal de São Paulo - DESAT - revelam um crescimento significativo $(62,2 \%)$ de licenças médicas por problemas vocais entre 1999 e 2001. Esses dados indicam urgência de estudos sobre o assunto, uma vez que os professores representam a maior categoria profissional no serviço público do município de São Paulo. Atualmente, segundo os mesmos dados, existem 39 mil professores em atividade no ensino municipal, e cerca de 500 profissionais encontram-se afastados das salas de aula por problemas vocais.

Estudos realizados por PENTEADO (1999) sobre a relação entre trabalho, saúde e qualidade de vida concluem que a voz é o instrumento de trabalho de aproximadamente $25 \%$ da população economicamente ativa, que dela depende, diariamente, para alcançar o sucesso de suas ocupações. Concluem que a voz expressa as condições individuais (físicas ou emocionais) e que, se o indivíduo não estiver em condições saudáveis, a voz deixará transparecer algum problema, ocasionando qualidade vocal disfônica, que pode vir a comprometer a fala e a comunicação. Concluem, também, que o indivíduo que padece de distúrbio vocal sofre limitações de ordem física, emocional e profissional. 
PEREIRA (1999), estudando professores da Secretaria Municipal de Educação de São Paulo, constatou que a maior parte não sabia avaliar se suas vozes necessitavam de cuidados, embora $75 \%$ estivessem com irritação na garganta, $62 \%$ relatassem rouquidão e cansaço ao falar, $47 \%$ apresentassem pigarro e $37 \%$ já tivessem perdido a voz.

ESTEVE (1999) elaborou estudo com fichas médicas referentes ao afastamento de professores por doenças, encontrando causas traumatológicas, otorrinolaringológicas e psiquiátricas. Relata que a ocorrência do estresse ocupacional tem sido observada em todas as partes do mundo, como fator causal de mortalidade, morbidade e ruptura na saúde mental e bem-estar dos professores.

Diz que o impacto dos fatores estressantes sobre profissões que requerem grau elevado de contato com o público recebe o nome de Síndrome do Burnout. Trata-se de uma resposta ao estresse emocional crônico, sentido no desempenho da profissão, representado por: exaustão física e emocional, diminuição da realização profissional no trabalho, despersonalização, depressão.

Descreve Burnout como a síndrome da exaustão emocional que apresenta três características principais: esgotamento físico e mental em grau máximo; despersonalização - perda do sentido das pessoas, visualizando-as como objetos; falta de envolvimento com o trabalho - distanciamento com as relações existentes no trabalho.

Em estudo realizado no município de Rio Claro, em São Paulo, enfocando os afastamentos de professores por licença médica, CARNEIRO (1997) encontrou como causas principais de afastamentos, doenças do aparelho respiratório, 
do sistema osteomuscular e tecido conjuntivo, doenças relacionadas a transtornos mentais.

Quanto às repercussões à saúde dos professores, fatores semelhantes foram descritos como causa de sofrimento por estudo abrangente, de âmbito nacional, realizado pelo Laboratório de Psicologia do Trabalho da Universidade de Brasília que, considerando variáveis como condições físico-ambientais, segurança, absenteísmo de professores, formas de interação escola-comunidade, constatou os anseios, as emoções, os desalentos vividos no decorrer da profissão docente ( $C O D O$, 1999).

Considerando que a saúde está fortemente relacionada aos modos de vida e às situações de trabalho, o campo desta pesquisa delimita-se a investigar as vivências de professores do Ensino Básico de Escolas do Município de São Paulo e buscar as causas de insatisfação/satisfação ou dificuldades sentidas no trabalho e como incidem no desempenho e em problemas de saúde.

\subsection{O TRABALHO EDUCATIVO NO ÂMBITO MUNICIPAL}

A Prefeitura do Município de São $\mathrm{Paulo}^{3}$, com todas as suas autarquias, tem o porte de uma grande empresa. São cerca de 120.000 servidores, distribuídos por diversas funções, dispersos nos mais diferentes locais de trabalho e expostos a inúmeros riscos. Apesar da complexidade, segundo levantamento realizado por esta pesquisadora, junto ao departamento responsável pela vida

\footnotetext{
${ }^{3}$ Fonte de Dados - CONAE - Coordenadoria dos Núcleos de Ação Educativa da SME, 2001.
} 
funcional, não se constata a implementação de uma política clara de promoção à saúde dos servidores.

O Departamento de Saúde dos Trabalhadores (DESAT) e o Departamento de Recursos Humanos (DRH), legalmente responsáveis pelas atividades de promoção à saúde, atuam principalmente e, em alguns momentos com exclusividade, nas atividades periciais.

O DESAT criado no ano de 2001 com o objetivo de transformar a relação médico pericial em uma visão multiprofissional da relação do homem com o seu trabalho e a sua saúde. Busca comprometer a administração e o servidor com a saúde e segurança nos ambientes de trabalho. Visa, ainda, consolidar uma relação entre atividade pericial, trabalho médico e atividade de profissionais que atuam na área de saúde do trabalhador.

Esse departamento foi estruturado para atender, de forma humanizada, as atividades periciais e, ao mesmo tempo, implementar ações que possibilitem mudanças no ambiente e no modo de organização do trabalho (Anexo I).

Ainda que o novo órgão criado tenha como objetivos humanizar o atendimento pericial, aumentando a eficiência dos serviços prestados, e consolidar a área de promoção à saúde, as ações de prevenção às doenças ainda ocorrem de maneira tímida.

No município, os processos de readaptação e restrição de funções são regidos pela Lei $n^{\circ} 11.434$, de 12/11/1993, alterada pela Lei $n^{\circ} 13.500$, de 08/01/2003 que dispõe: “... aos profissionais de Educação, docentes titulares de cargos e considerados estáveis no serviço Público Municipal, são concedidos os direitos de readaptação, temporária ou permanente, nos termos da legislação vigente, para os 
que apresentarem comprometimento parcial e permanente ou parcial e temporário de saúde fisica ou psiquica, atribuindo-se-lhes encargos mais compativeis com sua capacidade...". Aos não estáveis: “... restrição de função temporária ou permanente, nos termos da legislação vigente, para os que apresentarem comprometimento parcial e permanente ou parcial e temporário, de saúde fisica ou psiquica, atribuindo-se-lhes encargos mais compativeis com sua capacidade...".

Levantamento preliminar aponta, em dados quantitativos e qualitativos, a situação dos servidores readaptados do Quadro da Secretaria Municipal de Educação:

Quadro 1. Distribuição do número e porcentagem de especialistas readaptados na Secretaria da Educação do Município de São Paulo

\begin{tabular}{lccc}
\hline \multicolumn{3}{c}{ Especialistas } & \\
\hline Categoria funcional & Não readaptados & Readaptados & $\%$ \\
\hline Supervisor Escolar & 151 & 00 & $0 \%$ \\
Diretores de Escola & 760 & 01 & $0,1 \%$ \\
Coordenadores Ped. & 973 & 07 & $0,6 \%$ \\
\hline Total & 1.884 & 08 & $0,4 \%$ \\
\hline
\end{tabular}

Fonte: Dados do arquivo do setor de Recursos Humanos da Coordenadoria dos Núcleos de Ação Educativa da Secretaria Municipal de Educação, hoje, Coordenadoria Regional de Educação de Pirituba, 2001 
Quadro 2. Distribuição do número e porcentagem de professores titulares readaptados na Secretaria da Educação do Município de São Paulo

\begin{tabular}{lccc}
\hline \multicolumn{4}{c}{ Professores Titulares* } \\
\hline Modalidade/ensino & Não readaptados & Readaptados & $\%$ \\
\hline Educação Infantil & 5.354 & 284 & $5,3 \%$ \\
Fundamental I & 8.105 & 365 & $4,4 \%$ \\
Fundamental II & 7.166 & 326 & $4,6 \%$ \\
Deficientes Auditivos & 58 & 0 & $0 \%$ \\
Ensino Médio & 38 & 0 & $0 \%$ \\
\hline Total & 20.721 & 975 & $2,8 \%$ \\
\hline
\end{tabular}

Fonte: Dados do arquivo do setor de Recursos Humanos da Coordenadoria dos Núcleos de Ação Educativa da Secretaria Municipal de Educação, hoje, Coordenadoria Regional de Educação de Pirituba, 2001

*Professor Titular: professor efetivo, concursado, titular de cargo

Quadro 3. Distribuição do número e porcentagem de professores adjuntos readaptados na Secretaria da Educação do Município de São Paulo

Professores Adjuntos*

\begin{tabular}{lccc}
\hline Modalidade/ensino & Não readaptados & Readaptados & $\%$ \\
\hline Educação Infantil & 1.751 & 37 & $2,2 \%$ \\
Fundamental I & 4.299 & 62 & $1,5 \%$ \\
Fundamental II & 4.071 & 82 & $2,0 \%$ \\
Deficientes Auditivos & 23 & 0 & $0 \%$ \\
Ensino Médio & 50 & 0 & $0 \%$ \\
\hline Total & 10.194 & 181 & $1,1 \%$ \\
\hline
\end{tabular}

Fonte: Dados do arquivo do setor de Recursos Humanos da Coordenadoria dos Núcleos de Ação Educativa da Secretaria Municipal de Educação hoje, Coordenadoria Regional de Educação de Pirituba, 2001

*Professor Adjunto: professor efetivo, concursado, não titular de cargo 
Quadro 4. Distribuição do número e porcentagem de profissionais readaptados pertencentes a outros quadros

\begin{tabular}{lccc}
\hline Quadros & Não readaptados & Readaptados & $\%$ \\
\hline Contratados & 3.590 & 00 & $0 \%$ \\
Servidores do QPS* & 1.108 & 26 & $2,5 \%$ \\
Servidores do QPA** & 62 & 00 & $0 \%$ \\
\hline Total & 4.760 & 26 & $0,8 \%$ \\
\hline
\end{tabular}

Fonte: Dados do arquivo do setor de Recursos Humanos da Coordenadoria dos Núcleos de Ação Educativa da Secretaria Municipal de Educação hoje, Coordenadoria Regional de Educação de Pirituba, 2001

*Q.P.S.: Pessoal do quadro da saúde que presta serviços à educação

**Q.P.A.: Pessoal do quadro da administração que presta serviços à educação

Considerando que a emissão dos laudos médicos, condição imprescindível para a readaptação, é feita sob diferentes terminologias, para efeito de organização geral dos dados, computam-se também os números referentes à restrição de funções cuja diferenciação é somente de caráter funcional, como demonstrado no Anexo II.

Este cuidado foi tomado tendo em vista que, independentemente da situação funcional, os servidores readaptados ou com restrições de funções recebem o mesmo tratamento:

a) Readaptação Funcional para o servidor efetivo, docente titular de cargo estável no serviço público municipal.

b) Restrição de Função para o servidor admitido em caráter temporário ou contratado, não estável.

Quanto à natureza os Laudos Médicos, podem ser:

a) Definitivos, com despacho decisório e final. 
b) Temporários, sujeitos a sucessivas convocações num prazo de seis meses, um ano ou dois anos.

Quanto aos teores dos laudos emitidos pelo Departamento Médico, constata-se uma constância nas restrições apontadas, traduzidas em atividades compatíveis com as condições físicas e ou psíquicas do servidor.

A atividade atual dos profissionais readaptados em caráter permanente fica restrita aos teores dos laudos emitidos pelo Departamento Médico do Município, sendo atribuídos aos referidos servidores encargos mais compatíveis com a capacidade física ou psíquica, dependendo de exame comprobatório.

O estudo sobre a possibilidade de retorno às funções originais constatou que não há, atualmente, na Secretaria Municipal de Educação, projeto ou estudo visando melhor aproveitamento dos readaptados, dentro dos níveis permitidos pelos laudos, ou recuperação e retorno às atividades originais da função.

\subsubsection{A Escola Pública Municipal}

A escola pública é uma instituição específica, com tarefa eminentemente educativa e social que, por isso mesmo, exige esforço coletivo para enfrentar, com êxito, as suas dificuldades, porque essas dificuldades são antes institucionais que de cada professor.

Nas duas últimas décadas, quando a forte oscilação na economia resultou na estagnação da renda per capita, as condições de produção e reprodução da pobreza ganharam nova dimensão. Acreditou-se, todavia, que o combate à alta inflação e a implementação de um novo modelo mundial fossem capazes de reverter 
a natureza de manifestação da pobreza POCHMANN (2002), o que parece não ter ocorrido.

O município de São Paulo, mais populoso e principal pólo industrial do país, não foi uma exceção à regra brasileira. Pelo contrário, conviveu e convive com parcelas importantes de sua sociedade na pobreza, excluídas dos beneficios sociais.

A partir de 1988 houve mudança profunda no papel dos municípios dentro da organização federativa. O município era órgão administrativo subordinado ao Estado em que se localizava. A nova Constituição Federal elevou os municípios à condição de ente federativo autônomo. Com isso alterou-se, completamente, a organização dos sistemas de ensino federal, estadual e municipal. A Constituição Federal estabeleceu que os Estados, o Distrito Federal e os Municípios devem organizar, em regime de colaboração, os seus próprios sistemas de ensino.

O sistema municipal de ensino organiza-se, em São Paulo, como uma importante rede escolar composta, eminentemente, por Educação Básica, com unidades: Centros de Educação Infantil (CEI), Escolas de Educação Infantil (EMEI), Escolas de Ensino Fundamental (EMEF), Escolas de Ensino Fundamental e Médio (EMEFM), Centros de Educação Unificados (CEU) e Centros de Educação da Cultura Indigena (CECI).

A Secretaria da Educação do Município de São Paulo, no início do presente estudo, subdividia-se em 13 (treze) Divisões Regionais, denominadas Núcleos de Ação Educativa, distribuídas pelas diferentes regiões do Município. Em 2001, foram criadas 31 subprefeituras, em São Paulo, modificando a estrutura organizacional da Secretaria da Educação. Prevista pela Lei Orgânica do Município 
desde 1990, a implementação das subprefeituras foi concretizada com a regulamentação do novo modelo de gestão descentralizada da Prefeitura de São Paulo, pela lei 13.399 , de $1^{\circ}$ de agosto de 2002.

As 31 subprefeituras dão origem a um novo ordenamento dos serviços municipais: as sedes foram adequadas; os servidores, transferidos e capacitados em diferentes áreas. De acordo com o novo ordenamento, ficam a cargo das subprefeituras os serviços e verbas das Secretarias, a responsabilidade pela manutenção dos equipamentos municipais, o atendimento à população.

As antigas Diretorias Regionais de Educação foram subdivididas em 31 Coordenadorias de Ensino, cada uma com sede em uma Subprefeitura.

\subsubsection{Contexto da ação educativa}

No século passado, o Brasil esteve entre os países que apresentaram as mais altas taxas de crescimento da economia, em um processo de desenvolvimento nacional esgotado na década de 80 . A partir daí, em cenários de maior ou menor inflação, passou por um tempo de estagnação. Esse processo de baixo crescimento acentuou as desigualdades geradas pelo modelo econômico da época, agravando seus aspectos mais perversos: a perda de postos de trabalho, o declínio da renda e a restrição de direitos para a maioria da população.

Nesse contexto, a trajetória histórica da cidade de São Paulo também foi abalada. O município apresentou, durante o século passado, uma das maiores 
taxas mundiais de expansão econômica e demográfica. Passou de 240 mil habitantes em 1900, para 10,5 milhões, em $2000^{4}$.

Milhões de imigrantes e migrantes aqui aportaram em busca de trabalho. Foi uma época de grandes construções e crescimento das atividades produtivas. Mas o padrão de desenvolvimento adotado, mesmo apresentando forte dinamismo, também fez da mais pujante cidade do país um dos principais focos da desordem urbana, da desigualdade social e da agressão ambiental.

O crescimento desordenado e excludente da cidade trouxe chagas profundas: a impermeabilização do solo, a ocupação de periferias longinquas desprovidas de serviços, a opção pelo transporte individual em detrimento do coletivo, transformando o trânsito de São Paulo em um dos mais caóticos.

O desenvolvimento urbano da cidade de São Paulo é recente. Caracteriza-se por avanços sobre áreas de proteção de mananciais, eclosão de loteamentos clandestinos, sem infra-estrutura adequada, o que gerou ocupação desordenada de áreas de risco.

Houve um processo acelerado de miserabilização da cidade, que atualmente conta com 2.018 favelas, nas quais moram 1,16 milhões habitantes.

A população de rua cresceu assustadoramente, como também cresceu o número de vendedores ambulantes, modificando a paisagem de importantes regiões da cidade. Surgiram bairros que abrigam muitas construções de madeira, houve rápido aumento de locação em habitações precárias, proliferação de cortiços, aumento contínuo da taxa de desemprego. Somando-se a isso, a cidade de São Paulo

\footnotetext{
${ }^{4}$ *Fonte: Secretaria Municipal de Desenvolvimento, Trabalho e Solidariedade de São Paulo, 2004.
} 
tem, hoje, cerca de um milhão de portadores de deficiências de diferentes especificidades.

Ao mesmo tempo, acompanhando a tendência das grandes metrópoles mundiais, a economia da cidade mudou de perfil, com drástica redução de indústrias e aumento de prestação de serviços. Conforme estudo da Secretaria Municipal de Desenvolvimento, Trabalho e Solidariedade, na década de 70, cinco a cada 10 empregados estavam nas indústrias. Até 2020 , oito a cada 10 ocupados estarão nas chamadas atividades terciárias.

Em São Paulo, os maiores bancos do país instalaram suas sedes, e há cerca de 300 empresas multinacionais em plena atuação. Ainda assim, a taxa de desemprego chega a $20 \%$ da população economicamente ativa (mais de um milhão de pessoas desempregadas).

Esse quadro, além do sofrimento causado à população e redução da qualidade de vida, foi decisivo para instauração de inseguranças nas pessoas, na sociedade e fez aumentar a demanda da população por serviços públicos, principalmente nas áreas de educação e saúde, o que exerceu forte pressão sobre a administração do município.

Hoje, a região metropolitana de São Paulo é composta pela capital e por mais 38 (trinta e oito) municípios, ocupando uma área de 8.051 quilômetros quadrados. Sua população é de 17.306.000 habitantes, e sua produção anual atinge o montante de US $\$ 143$ bilhões, o que corresponde a 18,3\% do PIB do país.

A cidade de São Paulo, por sua vez, ocupa uma área de 1.509 quilômetros quadrados, dos quais $900 \mathrm{~km}^{2}$ são urbanizados. Sua população é de 
10.500.000 habitantes, e sua produção anual corresponde à expressiva soma de US\$ 70 bilhões, equivalentes a $9,6 \%$ do PIB do país.

Quanto à mão de obra, $79 \%$ das vagas estão nas áreas de comércio e serviços; $17,8 \%$ na área da indústria e 2,4\% em construção civil.

A cidade de São Paulo atua em sistema de conurbação com cidades próximas e convive com desigualdades sociais profundas.

O sistema de Ensino da Prefeitura do Município de São Paulo está organizado estruturalmente pela Secretaria Municipal de Educação, por uma Coordenadoria Geral de Ensino e cerca de 31 Coordenadorias Regionais de Ensino, estas com sede nas subprefeituras. Essa estrutura é responsável pelo funcionamento de 1.075 escolas, num total de 1.041 milhões de alunos e, ainda, 70 mil crianças em creches conveniadas e 300 mil alunos no MOVA - Movimento de Alfabetização de Jovens e Adultos.

As Escolas Municipais contam com um quadro de:

- Especialistas: Supervisores, Diretores de Escola e Coordenadores Pedagógicos;

- Docentes: Professores Titulares e Adjuntos;

- Apoio: Agentes e Assistentes Administrativos. 
Quadro 5. A Educação Municipal em Números

\begin{tabular}{cccc}
\hline & S.M.E & $\begin{array}{c}\text { Coord. Lapa, Pirituba, } \\
\text { Perus }\end{array}$ & $\begin{array}{c}\text { \% Coord. Lapa, } \\
\text { Pirituba, Perus }\end{array}$ \\
\hline ALUNOS & 1.041 .000 & 80.560 & $8,65 \%$ \\
PROFESSORES & 37.963 & 2.601 & $8,33 \%$ \\
FUNCIONÁRIOS & 15.733 & 1.427 & $8,04 \%$ \\
SERVIDORES & 53.696 & 4.028 & $8,22 \%$ \\
CLASSES & 25.194 & 2.218 & $8,80 \%$ \\
SALAS & 8.581 & 747 & $8,70 \%$ \\
ESCOLAS & 1.075 & 81 & $9,14 \%$ \\
\hline
\end{tabular}

Fonte: Secretaria Municipal de Desenvolvimento, Trabalho e Solidariedade de São Paulo, ano 2004.

Quadro 6. Total de servidores da Secretaria Municipal de Educação

\begin{tabular}{lcc}
\hline Quadro de servidores & Número de servidores & Percentual \\
\hline Quadro do magistério & 37.963 & $70,5 \%$ \\
Quadro de apoio & 10.973 & $20,6 \%$ \\
Outros quadros & 4.760 & $8,9 \%$ \\
\hline Total & 53.696 & $100 \%$ \\
\hline
\end{tabular}

Fonte: Secretaria Municipal de Desenvolvimento, Trabalho e Solidariedade de São Paulo, ano 2004.

\subsubsection{O ambiente da Escola Pública Municipal}

O ambiente de trabalho constitui o conjunto de fatores interdependentes, que influi direta e indiretamente na qualidade de vida das pessoas e nos resultados do próprio trabalho (PARAGUAY, 1997). Essa visão global das influências do trabalho facilita a compreensão das dificuldades e desconfortos, da insatisfação, dos baixos desempenhos, do surgimento de doenças ou ocorrência de acidentes e incidentes no trabalho. 
A análise do contexto infere que a escola é o espaço privilegiado onde se operacionalizam as proposições das políticas públicas; onde as ações buscam atingir as finalidades. É o lugar do cruzamento do projeto coletivo e político da sociedade com os projetos pessoais e existenciais dos educadores. É a escola que viabiliza a possibilidade de as ações pedagógicas tornarem-se educacionais, na medida em que as impregna das finalidades políticas da cidadania que interessa aos educandos. Se, de um lado, a sociedade precisa da ação dos educadores para a concretização de seus fins, de outro, os educadores precisam do dimensionamento político do projeto social para que sua ação tenha real significado na mediação da humanização dos educandos.

A Lei de Diretrizes e Bases da Educação Nacional (9394/96) dispõe da necessidade de um novo professor para fazer frente às demandas da pósmodernidade. Contudo, não houve por bem adotar medidas efetivas que garantissem o provimento do que se decidiu requerer em Lei. Desse modo, constata-se que o clima de insegurança instalado pelo fato de os professores não se sentirem preparados para responder às demandas do ensino atual soma-se às hostilidades das relações professor/aluno, vez que esses, da mesma forma, não têm logrado obter grandes satisfações com a escola. Os exames de avaliação externa realizados anualmente pela Secretaria Estadual de Educação e pelo MEC demonstram que o desempenho dos alunos das escolas públicas está muito aquém do esperado. Face a estas questões, levanta-se a hipótese de estar obsoleta a instituição Escola, diante dos avanços tecnológicos e científicos, das novas necessidades sociais e demanda dos alunos. 
"O professor, mais do que qualquer outro, é afetado por esta crise. $O$ que está em jogo, hoje, não é apenas a eficácia de seu desempenho em sala de aula, nem a qualidade de sua formação, mas o próprio significado de sua prática" (FERREIRA, 1998).

ALONSO (1999) aborda as inseguranças e incertezas como marcas da pós-modernidade. Argumenta que os avanços tecnológicos proporcionaram excessiva rapidez na divulgação das informações, rompendo antigas certezas ideológicas, e que passamos a viver em uma época quando as certezas são relativas e as verdades, passageiras.

"Os desafios são grandes e os professores, diante deles, mais parecem pigmeus. A seu favor têm muito pouco: sua frágil e ultrapassada formação, suas crenças - especialmente no que concerne à capacidade humana de aperfeiçoamento - e, quem sabe, seu ideal em termos de educação" (ALONSO,1999).

Quanto à divisão de responsabilidades, segundo a Lei de Diretrizes e Bases da Educação Nacional, cabe ao Estado atribuir aos Municípios a responsabilização pelas Escolas de Educação Básica. Essa responsabilidade implica, no caso do Município de São Paulo, assumir as escolas localizadas, na grande maioria, nas periferias de áreas centrais. Isso significa conviver com os mais diferentes problemas sociais que, não sendo pedagógicos, acabam adentrando às escolas.

A Escola Pública do Município de São Paulo atende crianças das regiões centrais e, de maneira significativa, atende populações de baixa renda, em região de extrema complexidade, carência e grande concentração populacional. 
Constituindo uma das maiores Redes de Ensino do país, a Escola Pública Municipal, pode-se dizer, sobrevive, hoje, em ambiente de violência, conflitos, professores insatisfeitos pela exigüidade das remunerações e pela falta de reconhecimento social.

\subsubsection{O professor de Educação Básica}

Legalmente, os quadros dos profissionais de educação, privativos da Secretaria Municipal de Educação, são compostos pelos cargos titularizados pelos servidores dos níveis superior, médio, básico e operacional que efetivamente exercem suas atribuições em unidades da referida Secretaria, compreendendo os cargos de provimento efetivo e em comissão.

Os cargos dos Quadros dos Profissionais da Educação são distribuídos em:

- Quadro do Magistério Municipal;

- Quadro de Apoio à Educação.

A carreira do Magistério Municipal configura-se da seguinte forma:

\section{. Classe I}

- Professor Adjunto de Educação Infantil;

- Professor Adjunto de Ensino Fundamental I;

- Professor Adjunto de Ensino Fundamental II;

- Professor Adjunto de Ensino Médio.

\section{. Classe II}

- Professor Titular de Educação Infantil; 
- Professor Titular de Ensino Fundamental I;

- Professor Titular de Ensino Fundamental II;

- Professor Titular de Ensino Médio.

\section{. Classe III}

- Coordenador Pedagógico;

- Diretor de Escola;

- Supervisor Escolar.

As carreiras que integram o Quadro de Apoio à Educação são as seguintes:

I - Agente Escolar

II - Auxiliar Técnico de Educação

Os cargos da Classe I, das carreiras que integram os Quadros dos Profissionais de Educação, são providos mediante concurso público de provas ou de provas e títulos.

Os cargos das Classes II e III da carreira do Magistério Municipal são providos mediante concurso público de provas e títulos e mediante concurso de acesso, dentre os titulares dos cargos de carreira.

Ainda que a estruturação da carreira continue a mesma, a introdução de novas abordagens sobre o conhecimento, no sistema educacional, e a nova ordem de relações socioculturais exigem um novo modelo de professor. A formação desse novo profissional constitui a essência das transformações requeridas pelas novas diretrizes, tanto pelos novos papéis que terão que desempenhar, como pela necessidade de que eles mesmos sejam os agentes transformadores da própria prática. 
O avanço das ciências permitiu que adquirissem certezas, mas, igualmente, revelou incertezas. O questionamento de verdades já consagradas, hoje, é uma constante. $\mathrm{O}$ advento da globalização, por sua vez, impõe mais um importante desafio aos currículos escolares que precisam estar atentos à cultura de conflitos, provenientes das diferentes referências de identidade, construídas pelos sujeitos nas relações sociais e no processo cultural. Nesse contexto, cabe ao professor perceber como esses referenciais operam na prática. Como agem classificando e hierarquizando sujeitos para, só então, concluir como poderá construir solidariedades que sustentem as lutas por eqüidade e justiça social.

Há de se convir que não se trata de um trabalho fácil, uma vez que o avanço das ciências e tecnologias aproximou o futuro do presente. Os profissionais do magistério, então, sentem dúvidas, pois que receberam um tipo de formação que não atende a todas essas reivindicações. Já não sentem segurança para atuar no âmbito dessas mudanças, no qual a demanda significativa se consubstancia na democratização das sociedades, tendo, como meta final, o desenvolvimento humano através da Educação. Essa proposta, obviamente, potencializa a responsabilidade do professor, angariando-lhe ainda mais insegurança. Segundo MELLO (1994), a educação hoje é convocada para expressar uma nova relação entre desenvolvimento e democracia. Alfabetizar para lidar com códigos e ter acesso às novas linguagens.

A qualificação, então, para atuar nessa nova realidade, requer profunda compreensão do contexto político e constitucional e o reconhecimento das especificidades das organizações, no caso as públicas, para a construção de novos paradigmas. 
Partindo daí, será preciso que os educadores utilizem instrumentos que permitam estabelecer relações mútuas e influências recíprocas entre as partes e o todo, promovendo um conhecimento capaz de apreender os problemas globais, hoje, inerentes a todos.

Em que pese a necessidade de se estabelecerem relações entre as partes e o todo, não é isso o que se verifica. A supremacia do conhecimento fragmentado desenvolvido nas escolas, aliada à obsolescência de métodos e técnicas, ainda hoje utilizados, não têm permitido que se estabeleçam as articulações necessárias. A demanda e expectativa do alunado têm ficado à deriva, sem norte, fato que leva também o aluno à insatisfação.

As escolas públicas, pela própria estrutura, são desprovidas de assistência técnica, criando necessidade de constante atualização por parte dos professores. A participação em cursos de capacitação, por sua vez, é feita por representatividade e não atinge a grande maioria dos professores. Como diz MELLO (1994), o sucesso do trabalho docente está condicionado ao conhecimento e à capacitação. Sem essas condições mínimas, não há como realizar um trabalho de sucesso, pois que falta a compreensão ampla dos fatores intervenientes no processo educacional. Falta, aos educadores, embasamento que efetuem as reorganizações técnicas que se fazem necessárias e que lhes possibilitaria intervir, de forma competente, nas condições de ensino-aprendizagem.

A Política Educacional do momento exige um novo professor, que seja capaz de rever e questionar a própria prática, mas não possibilita o acesso a formas de conhecimentos que possam transformar a situação instalada. As instituições públicas de formação apresentam um número reduzido de vagas, e os 
baixos salários não permitem que os professores ingressem em instituições particulares.

Segundo NÓVOA (1996), os professores encontram-se perante vários paradoxos. Por um lado são olhados com desconfiança, por outro, são bombardeados com uma retórica cada vez mais abundante que os considera elementos essenciais para a melhoria da qualidade de ensino. Pede-lhes quase tudo, dá-lhes quase nada. Ainda, segundo NÓVOA, é por meio dessas contradições que os professores têm de refazer uma identidade profissional, tanto individual quanto coletiva.

Mas a atualização de conhecimentos não é fácil ao professor, pelos motivos já expostos e porque os salários reduzidos não permitem a assunção de qualquer ônus.

Quando têm oportunidade de participar de cursos de capacitação, pouco podem aproveitar do conteúdo desses cursos, no trabalho diário, devido ao fato de que as condições materiais existentes nas Escolas, muitas vezes, não possibilitam a aplicação dos novos conhecimentos. Faltam verbas para a aquisição de recursos materiais, e as condições de espaço físico, no geral, impossibilitam qualquer nova configuração de turmas que não a tradicional: a sala de aula com as carteiras enfileiradas.

Ante o fracasso dos alunos, o professor questiona o seu papel de educador. E nesse questionamento não vê sentido no trabalho que realiza, pois que o mesmo não lhe parece significativo, pela falta ou pelos baixos resultados obtidos. A evasão e a repetência constituem os problemas mais sérios enfrentados pelos professores, atualmente, conforme argumentam (MELLO, 1994; SILVA, 1993). 


\subsubsection{O trabalho docente: satisfação e saúde}

A negação ao homem da possibilidade de cultivar o espírito trabalhador e empreendedor explicaria por que sua atividade se torna, muitas vezes, destrutiva, e não potencializadora das capacidades humanas, como seria desejável. Quando isso acontece, há sempre um processo de reação. Esse processo, afirma LAURELL (1989), pode ser identificado pela própria percepção dos trabalhadores, pelo conhecimento da problemática que envolve o local e o próprio trabalho e pelo grau de satisfação ou insatisfação demonstrado.

O homem é um ser histórico-social que constrói, transforma a sociedade em que vive e é moldado por ela, num movimento dinâmico e indivisível. A saúde, por sua vez, é um dos produtos desse movimento dinâmico e indivisível homem-realidade exterior. Enquanto unidade biopsicossocial, o homem responde globalmente aos acontecimentos em sua vida, uma vez que esses acontecimentos são dependentes, fundamentalmente, do modo de vida numa determinada época, sociedade, grupo e comunidade.

Os modos de vida são determinados socialmente, e o homem vai se adaptando plasticamente por meio de mudanças nos processos biológicos e psíquicos. Na concepção de LAURELL \& NORIEGA (1989), não se trata de uma adaptação à concepção fisiológica, em que o organismo retorna ao estado normal após adaptar-se, mas trata-se de uma adaptação para permitir a sobrevivência, com conseqüências muitas vezes inespecíficas, insidiosas e imensuráveis na totalidade que representa o homem. 
Tal processo de adaptação, segundo LAURELL (1989), converte-se em padrões de desgaste determinados pelas condições de vida do grupo social de pertença, não negando, entretanto, a possibilidade de respostas adaptativas atípicas, sobretudo no âmbito psíquico, em que a diversidade construtiva é anterior.

O homem é um animal simbólico que reage frente aos significados que ele próprio constrói historicamente, e não às coisas em si. Estes símbolos mudam o ambiente, a natureza, a sociedade e inscrevem-se no biológico (SAWAIA, 1994).

Os significados atribuídos em decorrência de valores culturais, familiares, pessoais, cumprem papel de mediadores, pois atuam na determinação das necessidades, desejos, expectativas das pessoas e, portanto, na determinação do que é saúde. A saúde estaria, então, condicionada à necessidade humana de transformar continuamente o mundo à sua volta, imprimindo-lhe significados particulares, construídos social e individualmente.

Nesta concepção, a saúde é uma questão eminentemente sóciohistórica e, portanto, ética, pois é um processo da ordem da convivência social e da vivência pessoal SAWAIA (1994), deixando de ser não doença ou estado de pleno bem-estar, para tornar-se possibilidade objetiva e subjetiva de estar sempre buscando este estado. $\mathrm{O}$ direito à saúde se revela como direito de ter essa possibilidade (SAWAIA, 1994).

"Saúde, então, é a possibilidade de ter esperança e potencializar esta esperança em ação. Promover a saúde equivale a lutar contra todas as formas históricas de violência do corpo e da alma, geradoras de servidão e heteronomia." (SAWAIA, 1994). 
O trabalho, enquanto necessidade humana, aparece como um dos elementos mediadores desta relação entre homem e sociedade, por meio do qual este homem realiza ações sociais, regulando-as de acordo com possibilidades e necessidades percebidas nele próprio e em seu ambiente, ou é impedido de tal feito, em decorrência de uma organização do trabalho rígida e heterodeterminada.

MORIN (2001) constata que a organização do trabalho deve oferecer aos trabalhadores a possibilidade de realizar algo que tenha sentido, de praticar e de desenvolver suas competências, de exercer seus julgamentos e seu livre-arbítrio, de conhecer a evolução dos seus desempenhos e de se ajustar.

Sobre este último aspecto, o ajustamento, é preciso lembrar que o trabalhador precisa não só ajustar-se, mas também ajustar a tarefa e as condições de sua realização às suas necessidades, seus desejos, suas capacidades e seu modo de ser (SATO, 1993).

Para HELLER (1998), a satisfação das necessidades de autodeterminação não significa liberdade absoluta e autonomia completa, nem que o homem esteja livre das determinações do contexto em que se insere, mas, sim, que ele deve poder atuar nesse contexto a partir do reconhecimento de suas necessidades, aspirações, desejos e ilusões. Para tal, utiliza a expressão enfrentar o contexto.

Segundo HELLER (1998), quando as formas da vida cotidiana se cristalizam, não deixando ao indivíduo a necessária liberdade de movimento, o indivíduo fragmenta-se em seus papéis, perdendo sua unidade enquanto ser humano.

Parece ser a partir daí que $S A W A I A$ define o sofrimento, enquanto objeto de estudo da psicologia social, da seguinte forma: a fixação do modo rígido de estado físico e mental que diminui a potência de agir em prol do bem comum, 
mesmo que motivado por necessidades do eu, gerando, por efeito perverso, ações contra as necessidades coletivas e, conseqüentemente, individuais (SAWAIA, 1994).

Adotar o sofrimento enquanto elemento central deste estudo significa reportar-se à esfera da vivência pessoal como fonte do conhecimento sobre o processo saúde-doença, possibilitando situar a pessoa no centro de produção do conhecimento (OLIVEIRA, 2000). Além disso, também privilegia o aspecto dinâmico dos mecanismos de adaptação e resistência elaborados e aplicados no cotidiano, como forma de preservar a saúde e a integridade psicológica e social. Assim, não é doença, mas aquilo que o homem identifica como fonte de sofrimento no cotidiano de trabalho, o foco do estudo.

Os estudos de LAURELL (1989) discutem a relação entre o processo de valorização, processo de trabalho e desgaste, pretendendo e propondo prever o que seja o padrão de desgaste de determinados grupos de trabalhadores em ambientes específicos. Argumenta que nos países do ocidente europeu, Canadá e Estados Unidos, os profissionais do ensino, em todos os graus, têm níveis de retribuição sensivelmente inferiores aos de outros profissionais com a mesma titulação. Esse fator, que em si mesmo não teria grande importância, contribui como um elemento a mais a constituir-se em prol do mal-estar, sobretudo quando o professor o associa com o aumento de exigências e responsabilidades que se lhe pedem no trabalho.

Sobre as fontes de estresse e insatisfação no trabalho, constatou que os problemas referentes à consideração social do seu trabalho, à crítica radical a seus modelos de educação e ao clima que rodeia a instituição de ensino, ao serem questões que os afetam profundamente, mas que não têm capacidade de dominar, 
propõem-lhes uma autêntica crise de identidade na qual os educadores questionam o sentido do seu próprio trabalho e, inclusive, a si mesmos.

Para a construção do bem-estar, três condições ou configurações dialeticamente articuladas são necessárias: participar dos bens materiais, dos bens simbólicos e dos bens sociais (SEVERINO, 1992). Ainda, segundo o autor, constituindo o professor um elo de vital importância nesse processo, para que atue eficientemente, duas condições básicas, relacionadas ao mesmo tempo, devem ser preenchidas: primeiro, condições de vida saudável com todos os seus determinantes (remuneração condigna, assistência à saúde, alimentação balanceada, tempo e oportunidade para reciclar-se) e, segundo, formação e educação contínuas.

O professor, personagem central do presente estudo, é, sem dúvida nenhuma, um profissional inserido no mercado de trabalho como os demais trabalhadores. Entretanto, as visões quanto às suas atividades são arraigadas de preconceitos e, muitas vezes, se equivocam ao comparar o ato de ensinar ao ato missionário. $L A G E$ (1982), em seu livro sobre ideologia e técnica da notícia, registra que o tratamento dado ao professor, em página do Jornal do Brasil, o distinguia das demais profissões e, inclusive, das demais matérias nas edições, porque usava uma linguagem que se caracteriza como homenagem.

Ainda, segundo $L A G E$, o texto do jornal reconhece a imagem do profissional ligada à idéia de profissional dedicado, mas reconhecimento mal pago. A matéria acaba colocando a remuneração como a causa do desprestígio do professor.

É provável, então, que pela forma equivocada de se perceber o trabalho educativo, poucas são as referências encontradas em relação aos problemas de saúde dessa categoria de profissionais. 


\subsubsection{Indicadores do mal-estar docente}

Nos últimos anos, mais precisamente na última década, têm aumentado as responsabilidades e exigências que se projetam sobre os educadores, coincidindo com um processo histórico de uma rápida transformação do contexto social, o qual tem sido traduzido em uma modificação do papel do professor. Às ações específicas de ensino, acrescentaram-se as de formação dos alunos, já que, entre outros motivos, a inserção da mulher no mundo do trabalho relegou à escola as responsabilidades, antes, atinentes às mães, o que implica uma fonte importante de mal-estar para muitos professores, já que não têm sabido ou, simplesmente, não têm aceitado acomodar-se às novas exigências.

Nesse sentido, GLOBE \& PORTER (1980) assinalam o aparecimento de dificuldades evidentes devidas à transferência, por parte da comunidade social e da família, de algumas de suas atividades protetoras, anteriores à escola, sem que essa transferência tenha sido acompanhada das necessárias mudanças na formação dos educadores, preparando-os para enfrentá-las com êxito, nem dos meios de que dispunham para responder às novas exigências; nem, por último, das necessárias mudanças estruturais para adaptar-se às novas circunstâncias.

Segundo os autores, em vez de se produzir uma adaptação sistemática à situação, tanto por parte dos professores quanto dos encarregados pela formação profissional, essa ampliação de papéis produziu um aumento de confusão no que se refere à capacitação de educadores e a quando e como se devia aplicá-la. Ou seja, produziu-se uma grande confusão com respeito à complexa função do professor. 
ESTEVE (1999) propõe a idéia de que o processo pelo qual os professores perdem prestígio social surge de uma atuação pouco eficaz com os alunos, que seria traduzida em uma diminuição substancial da satisfação, de sua implicação no trabalho, de sua motivação e de seu esforço, do que se chegaria, pela redução do esforço, a uma atuação ainda menos eficaz que tornaria a retroalimentar o ciclo.

O mal-estar que acomete os professores e as repercussões negativas sobre sua personalidade resultariam da discrepância entre o esforço do professor e os benefícios obtidos com tal esforço.

A ambigüidade da expressão mal-estar docente torna difícil a configuração da sua presença. A dor é algo determinado que se pode localizar. A doença tem sintomas manifestos. Porém, quando se fala em mal-estar, sabe-se que alguma coisa não vai bem, mas não se é capaz de definir o que não funciona e por que não funciona.

\subsubsection{O sofrimento do professor}

Segundo DEJOURS (1997), o sofrimento designa o campo que separa a doença da saúde. Entre o homem e a organização prescrita para a realização do trabalho, existe, às vezes, um espaço de liberdade que autoriza uma negociação do modo operatório, para adaptá-lo às suas necessidades e, mesmo, para torná-lo mais congruente com o seu desejo. Logo que esta negociação é conduzida a seu último limite, e que a relação homem-organização do trabalho fica bloqueada, começa o domínio do sofrimento e da luta contra o sofrimento. 
Para DEJOURS (1997), o sucesso ou o fracasso de uma tarefa obrigatória estão relacionados diretamente ao nível de qualificação, e conseqüentemente, à adaptação do conteúdo da tarefa às competências reais do trabalhador.

Diz, ainda, DEJOURS (1997) que o nível de qualificação não é, via de regra, suficiente em relação às aspirações. O sofrimento começa quando a evolução desta relação é bloqueada. Na adaptação do conteúdo da tarefa às competências reais do trabalhador, o sujeito pode encontrar-se em situação de subemprego de suas capacidades ou, ao contrário, em situação muito complexa, correndo risco de um fracasso. Tanto a circunstância de subemprego como a de qualificação aquém da tarefa causam insatisfação à pessoa.

DEJOURS (1997) acrescenta que na luta contra o sofrimento o indivíduo pode chegar a soluções desfavoráveis à produção e à sua saúde.

Uma das características do sofrimento é que não é explicitamente anunciado. Sua vivência é implícita, oculta, enigmática. Talvez por essa razão o sofrimento do professor traduz-se por uma inquietude polarizada pela abordagem de perspectivas negadas à carreira docente.

A psicologia social tem ajudado a compreender determinados sofrimentos cuja origem consta, marcadamente, de uma tensão entre os interesses individuais e as exigências sociais.

Por dois motivos, não é possível isolar o sofrimento do professor sem levar em consideração o contexto grupal intrínseco à sua profissão. Primeiro, porque é condição humana viver em sociedade; a formação psíquica se dá a partir da relação com o outro. Segundo, porque se trata de pessoa que escolheu essa profissão como 
forma de inserir-se socialmente. Sua intervenção profissional na realidade está marcada, portanto, por esse papel.

No caso do professor, tal papel liga-se a uma instituição social, o que determina que seu trabalho seja permeado constantemente por diversas relações grupais: com os alunos, com outros professores e com profissionais da instituição, por exemplo. E também por seu trabalho se processar dentro de uma instituição que, como tal, é representativa de um contexto social mais amplo.

Cada grupo tem seus sistemas próprios de funcionamento - objetivos, regras, hierarquias; o grupo familiar, o grupo de trabalho, de amigos -, mas a estrutura psíquica, que se forma desde a infância a partir do grupo familiar, orienta a relação do indivíduo com o outro e, portanto, com os demais grupos sociais.

As representações das pulsões individuais permanecem recalcadas no inconsciente. Se o indivíduo não for capaz de elaborar o conflito entre as pulsões recalcadas e as exigências do meio, surgirá, fatalmente, um sentimento de angústia, que o acompanhará como expressão de neurose (ADORNO, 1991).

Ainda que se tenha alcançado um progresso tecnológico inegável no que diz respeito ao controle da natureza, o que nos proporciona maior conforto material, não se conseguiu atingir o mesmo avanço nos assuntos propriamente humanos.

Esta é uma contradição da vida em sociedade analisada em diversos textos freudianos. O indivíduo só se constitui, e se diferencia, por intermédio da cultura. No entanto, essa mesma estrutura impõe um processo de indiferenciação para que o indivíduo possa ser aceito socialmente. 
Por um lado, temos como ideal cultural a autonomia e a liberdade individuais; por outro, os padrões de comportamento permitidos impõem uma absoluta restrição à individuação. Essa postura ambivalente que gera incertezas pode levar à angústia. O que pensam e exigem de mim? O que querem?

Dessa forma, o indivíduo é obrigado a investir boa parte de sua energia psíquica nas exigências culturais.

Essas exigências não levam em consideração a constituição singular de cada um, mas, ao contrário, forçam um comportamento homogeneizado que pode gerar inúmeras patologias, mais ou menos graves, conforme a constituição psíquica individual. Da forma como está estruturada, pode-se considerar que a sociedade é, portanto, responsável pela neurose ao impor sacrifícios ao indivíduo.

Segundo ADORNO (1991), os processos sociais subjugam de tal forma o indivíduo, determinando até mesmo o seu modo de pensar, que não lhe deixam espaço algum para uma verdadeira individuação.

A prova disso está numa questão básica da constituição da sociedade atual. Refere-se à relação entre o nível de progresso tecnológico alcançado por nossa cultura e sua conseqüência mais contraditória: a restrição à liberdade do indivíduo. Isto é, se alcançamos um conhecimento científico tal que nos permita garantir nossa sobrevivência com certa tranqüilidade, por que ainda permanecemos subjugados à necessidade de renúncia às satisfações individuais em nome de um trabalho penoso, por exemplo? Por que o progresso científico não nos alivia do sofrimento causado por alguns tipos de trabalho?

Talvez seja porque a satisfação, em nossa sociedade, não está atrelada aos interesses e necessidades do indivíduo, mas aos interesses e necessidades do 
sistema - social, econômico, político e cultural - que lança mão de mecanismos para subjugar seus membros às leis necessárias à sua manutenção.

O âmbito social sempre foi o mediador das necessidades humanas; no entanto, hoje, essas necessidades são externas aos indivíduos ( $A D O R N O, 1991)$. Para esse autor, a satisfação está atrelada ao que é ditado pelo mercado. O indivíduo está, portanto, à mercê de um jogo de interesses, os do mercado de consumo, bem distante de contemplar suas necessidades reais.

Através dos autores pesquisados, busca-se compreender como se conforma a relação entre o indivíduo e a sociedade. Percebe-se, com base nessas idéias, que não só o sofrimento é determinado socialmente, mas também a própria constituição psíquica o é.

No caso da Escola Pública, é curioso observar como a sociedade simplifica os males da escola, declarando os professores responsáveis universais por tudo o que nela possa haver de errado, inclusive quando se trata de problemas em que a responsabilidade real do professor e sua capacidade para evitá-los é muito limitada.

Hoje, os professores sofrem as conseqüências de estarem expostos a um aumento da tensão no exercício do trabalho, cuja dificuldade aumentou, fundamentalmente, pela fragmentação da atividade docente $e$ aumento de responsabilidades que lhes são exigidas, sem que se lhes tenha dotado dos meios e condições necessários para responder adequadamente. Mas, as exigências quanto à qualidade do trabalho não acontecem paralelamente a uma politica de proteção à saúde, à melhoria das condições de vida e trabalho (RIBEIRO, 1998). 
Ademais, o julgamento do trabalho docente geralmente se dá em sentido negativo. Se um professor faz um trabalho de qualidade, dedicando-lhe maior número de horas além das que configuram sua jornada de trabalho, poucas vezes se valoriza expressamente esse esforço suplementar; não obstante, quando o ensino fracassa, às vezes por um acúmulo de circunstâncias ante as quais o professor não pode operar com êxito, o fracasso se personaliza imediatamente, fazendo-o responsável direto pelas conseqüências.

Recentemente, um professor expressava esta idéia dizendo: "se tudo vai bem, os pais pensam que seus filhos são bons alunos. Mas se vai mal, pensam que nós professores somos maus educadores".

Como forma de sobrevivência, então, não resta ao professor da Escola Pública alternativa se não a de moldar-se às exigências que lhes são impostas, mas o desequilibrio entre suas forças internas e as condições adversas do trabalho docente o leva ao desânimo e desinteresse pelo próprio trabalho.

A desvalorização social aliada à demanda emocional conseqüente ao trabalho terminam por afetar seriamente a saúde desse professor. O absenteísmo e as licenças passam a ser uma constante em sua vida. Vivendo de licença em licença, afastado do convívio, sem estímulos ao trabalho, acaba por desinteressar-se de vez pela atividade docente.

O processo de readaptação, quando ocorre, não lhe traz maiores estímulos. O professor readaptado é o profissional que, considerado sem condições de assumir a sala de aula, dela é afastado, recebendo um rol de atribuições compatíveis com as suas condições de saúde, físicas e emocionais. Por isso sofre. 
Em que pese a solução encontrada para os que não mais podem assumir a docência, a sensação de inutilidade e invalidez não permite que os professores, nessas condições, tenham qualidade de vida satisfatória. Sentem-se sozinhos, culpados, envergonhados. A falta de condições ao trabalho produz sentimento de vazio, mal-estar, favorecendo o aparecimento da depressão, da angústia, desencadeando doenças.

Parece acertado dizer que o sofrimento do professor não termina com a emissão do laudo de readaptação. $\mathrm{Na}$ escola, muitas vezes, esse professor é discriminado pelos colegas que se imaginam injustiçados pela situação que consideram desigual. Julgam que o readaptado recebe sem trabalhar, enquanto eles têm que submeter-se a extensas jornadas. Em alguns casos, a qualidade de vida pósreadaptação passa a ser ainda pior.

Os Programas de Valorização do Profissional Readaptado, tanto da Secretaria da Educação quanto da área médica, pouco fazem a respeito. Timidamente tentam minimizar o sofrimento, o que nem sempre tem conseguido, provavelmente que pela falta de estudos mais aprofundados sobre as causas que implicam na readaptação e suas conseqüências.

É necessário, então, que se pense também nesse professor, muitas vezes, esquecido e desvalorizado pela sociedade a quem serve. Nesse professor, cuja constituição psíquica, talvez mais frágil, sucumbiu ante a ação das condições psicológicas e sociais em que se exerce a docência. Nesse professor que, dia a dia, vê rebaixar sua auto-estima. Que, sem sucesso, exige o direito de ser reconhecido como um trabalhador, na dignidade que lhe deve ser conferida, em relação à saúde e ao bem-estar. 
No que concerne ao processo de trabalho educacional, é lícito supor que não cabe a nenhum tipo de organização do trabalho o direito de subjugar o educador a um nível de exaustão laboral tamanha, capaz de invalidá-lo à atividade docente.

\subsubsection{Esgotamento profissional}

No que se refere à Síndrome de Esgotamento Profissional "Burnout", não existe uma única definição, mas sim um consenso de que esta é uma resposta ao estresse laboral crônico. Esse estresse está relacionado a uma experiência subjetiva dos indivíduos que leva a atitudes e sentimentos negativos, que implicam em alterações, problemas e disfunções psicofisiológicas, ocasionando conseqüências nocivas para o indivíduo e para a organização onde trabalha.

ESTEVE (1999) citando MASLACH \& JACKSON (1981) esclarece que em suas primeiras definições sobre a síndrome, verificou que esses autores a consideram como um estado de esgotamento físico, mental e emocional provocado pelo fato de o profissional estar exposto por um período de tempo prolongado a situações que exigem alta demanda emocional. Os sentimentos incluídos na síndrome são os sentimentos de indefesa, desesperança, desilusão, autoconceito e atitudes negativas, frente ao trabalho e aos colegas.

ESTEVE (1999) argumenta que esses autores consideram a identificação dos desencadeantes ou facilitadores da síndrome como uma tarefa complexa, pois qualquer moléstia crônica oriunda de situações do meio de trabalho pode ser estressora e, portanto, desencadeante ou facilitadora. 
O termo "Burnout" é utilizado para descrever o ciclo degenerativo da eficácia docente de que fala ESTEVE (1999). Explica, esse autor, que o esgotamento apareceria como conseqüência do mal-estar docente, e o termo vem designar o conjunto de conseqüências negativas que afetam o professor a partir de ações coligadas aos efeitos das condições psicológicas e sociais em que se exerce a docência.

Adianta que, com efeito, alguns autores tentaram descrever a evolução negativa do contexto social e psicológico da profissão docente. Não obstante, essa evolução negativa do contexto não afeta igualmente a todos os professores. Muitos deles conseguem encontrar respostas aos novos questionamentos. Outros reduzem sua eficácia e renunciam a um ensino de qualidade, mas ainda se mantêm na profissão, com níveis diferentes de inibição.

Alguns vivenciam a docência com uma postura contraditória: sabem que os antigos modelos não são válidos, mas ainda continuam a utilizá-los, talvez porque não saibam como substituí-los. Um último grupo, entretanto, acaba sendo pessoalmente atingido, em conseqüência da evolução negativa do contexto: o "malestar docente" acaba afetando esses professores em diferentes níveis.

Esse mal-estar difuso vai concretizar-se em absenteísmo, em pedidos constantes de transferências, em estresse, em doenças, às vezes, imaginárias para abandonar momentaneamente a docência e, por fim, em doenças reais, em neuroses reativas ou depressões mais ou menos graves (ESTEVE, 1999).

POLAINO (1982), entre outros, concorda em assinalar a falta de tempo para atender às múltiplas responsabilidades que se foram acumulando sobre os 
professores como causa fundamental de seu esgotamento, do que, posteriormente, podem advir outras conseqüências.

A idéia que se repete, para esse autor, é a de que o professor está sobrecarregado de trabalho, obrigando-se a realizar uma atividade fragmentária, na qual deve lutar, simultaneamente e em frentes distintas: deve manter a disciplina suficiente, mas ser simpático e afetuoso; deve atender individualmente as crianças sobressalentes que queiram ir mais depressa, mas também aos lentos, que têm de ir mais devagar; deve cuidar do ambiente da sala de aula, programar, avaliar, orientar, receber os pais e colocá-los a par dos progressos de seus filhos, organizar diversas atividades, atender freqüentemente a problemas burocráticos. A lista de exigências parece não ter fim.

As investigações sobre o esgotamento do professor mostram-no como um profissional ultrapassado, a quem, pela acumulação de responsabilidades e expectativas desproporcionais ao tempo e aos meios de que dispõe, obriga-se a realizar mal seu próprio trabalho.

Surge, então, a ansiedade da expectativa, segundo POLAINO (1982): uma ansiedade generalizada, indiscriminada e não seletiva, atenta à espera de que o seu comportamento ou a sua personalidade possam ser avaliados de forma pejorativa. A ansiedade dos professores deveria ser a regra, o normal; a depressão, uma de suas conseqüências mais freqüentes.

A citação de POLAINO nos permite centrar as conseqüências do malestar docente em suas verdadeiras dimensões. A pressão do contexto social e as dificuldades objetivamente existentes na prática do magistério não afetam a todos da mesma maneira. Entre eles, um numeroso grupo é capaz de romper esse mal-estar 
difuso, propondo novas respostas, criativas e integradas, para fazer frente aos novos problemas.

Entre os que sucumbem ante a ação das condições psicológicas e sociais em que se exerce a docência, os mais numerosos não são os que vêem sua saúde afetada por sintomas de estresse, neurose ou depressão, que ficam reduzidos a um número de casos quantitativamente significativo; os mais numerosos são os professores que recorrem, como uma reação de defesa, a mecanismos que lhes permitem romper a pressão à qual se encontram submetidos.

Em um trabalho anterior ESTEVE (1999) já mostrava como o significado que se dera à presença permanente de fontes de tensão no exercício diário da docência dependia da implicação pessoal, com que cada professor enfrentava o magistério. Essa mesma implicação pessoal que antes aparecia como fonte de autorealização apresenta, ao educador, uma ambivalência, tornando-se paradoxalmente a cara e a cruz de sua atividade educadora, efetivamente.

As respostas que a educação exige, na sociedade contemporânea, supõem para o professor uma profunda retidão pessoal, pois é no âmbito de sua capacidade de relação pessoal, e não no do conhecimento acumulado, ainda que este deva ser suposto, que o professor vai conseguir alcançar uma educação de qualidade. 


\section{OBJETIVOS}

\subsection{Objetivo Geral}

Descrever e analisar as condições de trabalho de educadores que atuam na área do Ensino Básico das escolas da Rede Municipal de Ensino de São Paulo, identificando as condições favoráveis e desfavoráveis do trabalho docente e sua repercussão na vida e no processo saúde-doença desses profissionais.

\subsection{Objetivos específicos}

- Descrever e analisar as condições de trabalho e de vida de professores do Ensino Básico das Escolas Públicas do Município de São Paulo;

- Analisar a inter-relação entre condições de trabalho e os processos de expropriação da saúde. 


\section{METODOLOGIA}

\subsection{Delineamento da pesquisa}

A explicitação da pesquisa, seus pressupostos, objetivos e finalidades dos resultados à população envolvida no estudo bem como a negociação do trabalho de campo são de fundamental importância, tanto para o seu desenvolvimento, como para o cumprimento ético da pesquisa em ciências humanas (PARAGUAY, 2000).

A metodologia do estudo, sem dúvida, a parte mais dificil de ser formulada, concerne à definição do que constitui o material da pesquisa.

O objetivo, no caso, não é a exposição da realidade do trabalho docente, em suas dimensões fisicas e cognitivas. Tem por fim, essencialmente, a vivência subjetiva, de modo que neste estudo interessa, sobretudo, a dimensão das falas, dos relatos dos educadores, relatos que incluem concepções subjetivas, hipóteses sobre o porquê e o como da relação vivência-trabalho.

Ainda que as problemáticas psicopatológicas individuais fiquem, evidentemente, envolvidas na pesquisa, o objetivo não é expô-las nem tratá-las. $O$ alvo da pesquisa é a relação do educador com o trabalho e os efeitos mascaradores dos sistemas coletivos de defesa em relação ao sofrimento. Indo além, visa descrever as modalidades de ação da organização do trabalho e seus possíveis efeitos nocivos à saúde. Importante conhecer, em princípio, a história das reivindicações, as situações de conflito, os ritmos de trabalho, a hierarquia organizacional, a supervisão, as contradições do dia a dia. 
Estabelecido o trabalho de campo, que consiste no recorte empírico da construção teórica elaborada, iniciados os primeiros levantamentos, confrontamo-nos com a refutação de algumas hipóteses, o que nos levou a rever questões operacionais para conseguir levar a cabo a pesquisa.

As estratégias estabelecidas a priori não se coadunavam com o grupo de pesquisa, o que ensejou reformulação das mesmas.

Ainda que o caminho a ser seguido na investigação já estivesse mapeado, na prática não se mostrou viável.

Verificamos que a grande maioria dos professores se sentia constrangida em participar de entrevistas. O fato de serem entrevistados por um Supervisor de Ensino causava-lhes bloqueio, ainda que soubessem tratar-se de um evento desvinculado da administração gestora das Unidades Escolares.

Dois tipos de preocupação dominavam os sentimentos dos interlocutores: o receio de servirem de instrumento de experiência e de verem as suas próprias condutas avaliadas e, portanto, julgadas pelo pesquisador, receio que consideramos legítimo.

A inserção do pesquisador em campo foi acompanhada de novas revelações na concepção da equipe: o Supervisor de Ensino, embora aceito pelo grupo, não deixa de ser autoridade.

Cabe esclarecer que, implícita ou explicitamente, a supervisão é reflexo de uma política e está a serviço dessa política. Historicamente, foi equacionada a partir de suas origens: as relações entre o homem e o trabalho, mais especificamente da separação entre a concepção e a execução do trabalho. 
Embora essa função não se manifeste explicitamente nas relações afetivas que se conseguem manter entre o supervisor e equipe de professores, estão eles cientes de que a supervisão foi concebida para exercer controle sobre o processo, como meio de correção de desvios entre o planejado e o executado.

É lícito supor, então, que essa consciência acabou sendo constitutiva de uma barreira entre entrevistados e entrevistador.

Foi preciso que se retomasse a discussão sobre a pesquisa, aclarandose objetivos e intenções, a fim de que fosse restaurada a confiança.

A princípio, a observação participante, realizada através do contato direto da pesquisadora com o fenômeno observado, viu-se um tanto prejudicada, uma vez que as idéias pré-concebidas a respeito da supervisão permeiam as relações e, dessa forma, interferem na produção de informações.

Como a descrição dos problemas através da elocução dos professores se fazia necessária, combinou-se que os depoimentos poderiam ser prestados através de questionários. Acertada a questão, a maioria dos entrevistados preferiu a forma de respostas, com identificação opcional, sob o argumento de sentirem-se mais à vontade para expor o que pensam e sentem.

Findas as considerações e iniciado o processo, em diálogo com o campo de estudo, houve uma sondagem preliminar que orientou o delineamento da pesquisa.

Após o delineamento, foi apresentado um resumo do projeto ao senhor Coordenador das Coordenadorias de Educação eleitas como locais de estudos.

A partir da apresentação foi solicitada, ao senhor Coordenador, permissão para se realizar a pesquisa. 
Em contato com os diretores das escolas referidas, o projeto foi apresentado, dando-se ênfase aos objetivos e finalidades do estudo, tendo sido assumido, pela pesquisadora, o compromisso de socializar os resultados e, pelo senhor Coordenador, o de garantir um espaço para a apresentação dos resultados. Em continuidade, os participantes foram convidados a compor o grupo de estudos por meio de termo de consentimento (Anexo III e Anexo IV).

Os estudos exploratórios têm como função, entre outras, aumentar o conhecimento do pesquisador acerca do fenômeno que deseja investigar, ou da situação em que pretende realizar tal estudo: esclarecimento de conceitos, estabelecimento de prioridades e obtenção de informações sobre possibilidades práticas de realização da pesquisa em situação de vida real. MORENO (1993) complementa que o principal objetivo de uma pesquisa exploratória é evitar que vieses profissionais do pesquisador interfiram na percepção do que está sendo observado.

Como satisfação ou insatisfação no trabalho podem variar em decorrência de aspectos subjetivos, sociais e culturais, a fase exploratória foi realizada para identificar a percepção da população de estudo, em relação ao conceito de satisfação no trabalho e à percepção de quais aspectos psicossociais do trabalho são considerados como influentes (positiva ou negativamente) sobre a satisfação e a insatisfação, bem como verificar se havia discrepância entre estes achados e os identificados na literatura.

Percepção é o ato pelo qual o indivíduo toma conhecimento de um objeto ou situação do meio exterior, por meio dos sentidos, e dá a ele um significado baseado em elementos da memória, do raciocínio, do juízo e do afeto. É um processo 
pelo qual o indivíduo acopla elementos subjetivos e próprios de cada pessoa às qualidades objetivas do mundo exterior. A percepção confere originalidade pessoal à realidade apreendida (BALLONE, 2001).

Levando em conta essa conceituação, o critério adotado para definir a amostra levou em consideração as limitações que este tipo de pesquisa exploratória impõe.

A partir do momento em que se priorizou estudar os educadores que manifestaram vontade de participar, não caberia, pois que incoerente, utilizar-se de critérios estatísticos para o estabelecimento do número de participantes ou de qualquer outro meio de seleção da amostra. Descartou-se, portanto, o critério da amostragem probabilística, ainda que ela ofereça certa segurança contra falsos resultados e garantia de estimativa dos efeitos para toda a população. Adotou-se, então, o critério de amostra não probabilística, do tipo acidental, que é a forma de se recorrer dos sujeitos que estão em disponibilidade.

O fato de se caracterizar como uma pesquisa exploratória, aliado ao interesse de se conhecerem, com maior profundidade, os vários aspectos do processo saúde-doença e trabalho, resultou em um tamanho reduzido da amostra o que, a nosso ver, não a invalida, pois o estudo exploratório pode ser encarado como o primeiro passo da pesquisa e favorece o conhecimento dos diferentes aspectos do processo.

Para a realização da fase exploratória foram convidados professores que prestam serviços na sede da Coordenadoria de Educação da Lapa. A receptividade dos mesmos foi considerada elemento facilitador ao desenvolvimento desta parte do estudo. 
Inicialmente, foram aplicados questionários a seis professores (quatro readaptados e dois não readaptados) dentre os convidados, tendo como objetivo a convalidação ou o redimensionamento das questões elaboradas para os procedimentos de pesquisa, considerando-se que esse grupo apresenta características semelhantes ao público-alvo da amostra.

Após a aplicação, a análise das respostas demonstrou a necessidade de reformulações, visto que o questionário elaborado fazia crer que a pesquisa avaliaria o desempenho individual de cada professor, o que não era a intenção.

A identificação dos participantes foi outro fator a ser considerado nessa fase exploratória, uma vez que se detectou certo constrangimento diante das indagações. Cientes de que a pesquisadora era uma supervisora de ensino, ainda que lá não estivesse como tal, apresentaram certa resistência no que concerne à identificação.

A partir dessas considerações, as questões indagativas foram reformuladas, adequando-as em conformidade com o que se havia detectado na fase exploratória.

Os procedimentos metodológicos para coleta e análise do material foram planejados a partir do evidenciado nessa fase exploratória.

O instrumento de coleta de dados teve como tema o número de alunos por classe, faixa etária, jornada semanal de trabalho docente, percepção da unidade escolar enquanto ambiente de trabalho, aspectos de problemas que consideram relevante, motivos de satisfação e insatisfação, vivência de relações entre trabalho e saúde, opinião sobre situações que podem conduzir à expropriação da saúde e à readaptação de professores. 


\subsection{Composição do grupo de estudo}

Dentre as escolas pertencentes à região escolhida para desenvolver a pesquisa, foram selecionadas unidades que concentram maior número de professores readaptados em seus quadros.

Para garantia de representatividade foram escolhidas Escolas de Educação Infantil, que trabalham com alunos na faixa etária de quatro a seis anos, e de Ensino Fundamental, que trabalham com alunos de sete a 14 anos de idade, ou mais.

Delimitou-se a área de abrangência onde se realizou o estudo, por motivos de:

- constituir um dos maiores núcleos da Secretaria da Educação, hoje, compreendendo as Coordenadorias de Educação da Lapa, Pirituba e Perus;

- abranger escolas situadas em áreas centrais do Município (Perdizes, Lapa, Pompéia) e em zonas periféricas, distantes (Pirituba, Jaraguá, Taipas, Perus), dominadas por regiões de invasão populacional;

- deter, nos quadros de profissionais das Escolas, número significativo de professores readaptados ou com restrição de funções.

Tal escolha deu-se com base no levantamento preliminar que apontou essas áreas como ambientes propiciadores de investigação, no que diz respeito a aspectos da relação trabalho/saúde dos servidores.

A escolha de algumas escolas situadas em regiões centrais do município e outras em regiões periféricas deu-se pelo fato de que as escolas pertencentes a Coordenadorias localizadas em regiões exclusivamente periféricas 
atuam com professores em início de carreira, na sua grande maioria, razão pela qual o número de readaptados, se houver, é reduzido.

Acredita-se que os professores readaptados, tendo percorrido desde o início o trajeto que evoluiu até o afastamento definitivo das funções, possam oferecer maiores contribuições à pesquisa.

As Coordenadorias escolhidas, em dados obtidos através do $\mathrm{PRP}^{5 *}$ até o final do ano de 2001, detêm um número de 227 laudos médicos de readaptações dos quais:

- professores titulares e adjuntos

- agentes escolares e apoio educativo

- coordenadores pedagógicos

A comparação numérica entre os readaptados professores e demais especialistas da área de educação e ou agentes de apoio educativo justifica a escolha dessa população como alvo de investigação.

Os critérios de inclusão no grupo de estudos objetivaram representatividade de subgrupos dentro do universo pesquisado, abrangendo as múltiplas dimensões do fenômeno a ser estudado. Em conseqüência, a definição das pessoas a serem entrevistadas contemplou os subgrupos: professores de educação infantil e professores de ensino fundamental.

Foram sujeitos do estudo 42 professores do Ensino Básico, sendo 36 do sexo feminino e seis do masculino, dos quais, 11 readaptados e 31 em exercício.

\footnotetext{
${ }^{5}$ PRP - Programa de Reaproveitamento de Pessoal, da Secretaria Municipal de Educação fundamental, nível I, professores de ensino fundamental, nível II. Professores readaptados, professores com anos de carreira, professores em início de carreira.
} 


\subsection{A coleta de dados}

O estudo do comportamento humano - suas atitudes, sentimentos, expectativas e motivações - encontra, na metodologia de coleta de dados, uma certa restrição. No caso específico da motivação, MURRAY (1986) afirma que: “... há acordo geral em que um motivo é um fator interno que dá inicio, dirige e integra o comportamento de uma pessoa. Não é diretamente observado, mas inferido do seu comportamento ou simplesmente, parte-se do principio de que existe a fim de explicar-se o seu comportamento...".

Considerando-se que o processo motivacional interno é, muitas vezes, dificil ou mesmo impossível de ser observado, optou-se pela utilização de um instrumento que levasse o próprio entrevistado a um autodiagnóstico.

A escolha incidiu sobre a aplicação de um questionário com perguntas semi-estruturadas e abertas (anexo V) por ser uma técnica que, pelo caráter anônimo de seu preenchimento, possibilita a obtenção de respostas as mais fidedignas possíveis. Outro aspecto considerado diz respeito à economia de tempo na sua aplicação: junto a um maior número de pessoas e em condições mais favoráveis de respondê-lo, por exemplo, no horário de trabalho coletivo dos professores.

Deve-se considerar que na avaliação que o indivíduo faz sobre a satisfação que sente em relação ao seu trabalho estão envolvidos aspectos subjetivos relacionados a valores, sentimentos e expectativas, uma vez que satisfação no trabalho é um estado emocional que envolve componentes cognitivos e emocionais. Esta complexidade faz com que o fenômeno seja difícil de ser mensurado e avaliado.

O questionário auto-aplicado, possibilitando a mensuração dos níveis 
de satisfação no trabalho e da condição de saúde, é aplicado como forma de identificar os aspectos psicossociais do trabalho que influenciam nos níveis de satisfação e verificar as associações entre os fenômenos satisfação e saúde.

Por meio da análise ergonômica, busca-se caracterizar a organização do trabalho e a manifestação de aspectos psicossociais sobre a saúde e bem-estar dos educadores e verificar quais destes aspectos podem ser considerados determinantes de satisfação ou insatisfações.

Para dar início à coleta de dados foram levantadas as escolas, tendo sido referidas as seguintes unidades: EMEI Ana Maria Poppovic, EMEI Dona Leopoldina, EMEI Jean Piaget, EMEI Noemia Ippólito, EMEI Santos Dumont, EMEF Aldo Ribeiro Luz, EMEF Dilermando Dias dos Santos, EMEF José Maria Pinto Duarte, EMEF Ferraz de Campos, EMEF Fernando Gracioso, jurisdicionadas às Coordenadorias de Educação da Lapa, Perus e Pirituba.

A elaboração dos questionários preocupou-se em formular questões que possibilitassem a caracterização do contexto de trabalho, partindo do conhecimento e vivência das pessoas que nele atuam, de modo a contemplar informações sobre como o trabalho docente pode interferir no processo saúde-doença dos educadores.

Quanto à intencionalidade da pesquisa, destaca-se aqui como algo a buscar o que BOURDIEU (1999) denominou como "escuta ativa e metódica, que associa a disponibilidade total em relação à pessoa interrogada, a submissão à singularidade de sua história particular, que pode conduzir, por uma espécie de mimetismo mais ou menos controlado, a adotar sua linguagem e a entrar em seus pontos de vista, em seus sentimentos, em seus pensamentos, como a construção 
metódica do conhecimento das condições objetivas, comuns a toda uma categoria".

Os questionários foram aplicados nas dependências das escolas. Esse processo teve a duração de três meses e ocorreu mediante consentimento por escrito.

\subsection{Análise dos dados}

Os depoimentos não foram reproduzidos na íntegra, tendo em vista a preservação da identidade dos participantes.

Optou-se por uma estratégia de apresentação e análise dos dados que permitisse ao leitor um contato amplo e direto com as partes mais significativas do conteúdo das respostas.

As respostas às questões fechadas foram transformadas em frequêencias e divididas em dois grupos: o dos professores em exercício e o dos readaptados. Foram, então, comparados os grupos no sentido de se verificar se entre eles havia alguma diferença estatisticamente significativa que permitisse identificar os agravos à saúde do professor, considerando-se o grupo de professores readaptados como representante dos eventuais indicadores de agravos à saúde do professor de escola pública municipal de São Paulo. Para que tal comparação pudesse ser realizada objetivamente foi utilizada a Prova do Qui-quadrado.

Com relação às respostas às questões abertas, foi considerada a intensidade das freqüências de respostas comuns a todos os entrevistados, cujos achados foram descritos e analisados à luz da literatura, propositalmente extensa, neste estudo, a fim de coibir prevalência da subjetividade da pesquisadora. 


\section{RESULTADOS}

A população da amostra foi composta por professores lotados em escolas pertencentes às Coordenadorias da Lapa, Pirituba e Perus da Secretaria de Educação do Município de São Paulo.

Do total de 42 professores entrevistados, 31 (74,0\%) estão em exercício e 11 (26,0\%), readaptados. Ressalte-se que todos os readaptados exercem, atualmente, atendimento ao público e/ou serviços operacionais. As Tabelas 1 e 2 mostram a distribuição dos professores em relação ao sexo e à idade. Houve predominância do sexo feminino $(86,0 \%)$, mas não se observou diferença entre os professores em exercício e os readaptados em relação ao sexo. Ao contrário, foi estatisticamente significativo o fato de todos os professores readaptados estarem em uma faixa etária superior à dos professores em exercício.

Tabela 1. Distribuição dos professores entrevistados em relação ao sexo

\begin{tabular}{lcccccc}
\hline Sexo & \multicolumn{2}{c}{$\begin{array}{c}\text { Professores em } \\
\text { exercício }\end{array}$} & \multicolumn{2}{c}{$\begin{array}{c}\text { Professores } \\
\text { readaptados }\end{array}$} & \multicolumn{2}{c}{ Total } \\
\cline { 2 - 7 } & $\mathrm{n}$ & $\%$ & $\mathrm{n}$ & $\%$ & $\mathrm{n}$ & $\%$ \\
\hline Feminino & 27 & 87,0 & 9 & 82,0 & 36 & 86,0 \\
Masculino & 4 & 13,0 & 2 & 18,0 & 6 & 14,0 \\
\hline Total & 31 & 100,0 & 11 & 100,0 & 42 & 100,0 \\
\hline
\end{tabular}

Qui-quadrado crítico: 3,84 - Qui-quadrado calculado: 0,01 (n.s.) 
Tabela 2. Distribuição dos professores entrevistados em relação à idade

\begin{tabular}{lcccccc}
\hline Idade & \multicolumn{2}{c}{$\begin{array}{c}\text { Professores em } \\
\text { exercício }\end{array}$} & \multicolumn{2}{c}{$\begin{array}{c}\text { Professores } \\
\text { readaptados }\end{array}$} & \multicolumn{2}{c}{ Total } \\
\cline { 2 - 7 } & $\mathrm{n}$ & $\%$ & $\mathrm{n}$ & $\%$ & $\mathrm{n}$ & $\%$ \\
\hline $20-30$ anos & 2 & 6,5 & 0 & - & 2 & 5,0 \\
$31-40$ anos & 8 & 25,5 & 0 & - & 8 & 19,0 \\
$41-50$ anos & 15 & 48,0 & 0 & - & 15 & 36,0 \\
$>50$ aos & 6 & 20,0 & 11 & 100,0 & 17 & 40,0 \\
\hline Total & 31 & 100,0 & 11 & 100,0 & 42 & 100,0 \\
\hline
\end{tabular}

Qui-quadrado crítico: 7,82 - Qui-quadrado calculado: 27,09(*)

Na Tabela 3 está a distribuição dos professores com relação ao estado civil, não havendo diferenças significativas nesta variável entre professores em exercício e readaptados. Interessante notar, porém, que $36 \%$ dos readaptados são divorciados, contra $3 \%$ dos professores em exercício.

Tabela 3. Distribuição dos professores entrevistados em relação ao estado civil

\begin{tabular}{lcccccc}
\hline Estado civil & \multicolumn{2}{c}{$\begin{array}{c}\text { Professores em } \\
\text { exercício }\end{array}$} & \multicolumn{2}{c}{$\begin{array}{c}\text { Professores } \\
\text { readaptados }\end{array}$} & \multicolumn{2}{c}{ Total } \\
\cline { 2 - 7 } & $\mathrm{n}$ & $\%$ & $\mathrm{n}$ & $\%$ & $\mathrm{n}$ & $\%$ \\
\hline Casado & 19 & 62,0 & 5 & 46,0 & 24 & 57,0 \\
Solteiro & 9 & 29,0 & 2 & 18,0 & 11 & 26,0 \\
Viúvo & 2 & 3,0 & - & - & 2 & 5,0 \\
Divorciado & 1 & 3,0 & 4 & 36,0 & 5 & 12,0 \\
\hline Total & 31 & 100,0 & 11 & 100,0 & 42 & 100,0 \\
\hline
\end{tabular}

Qui-quadrado crítico: 7,82 - Qui-quadrado calculado: 3,77 (n.s.)

Com relação ao nível de instrução, dos professores em exercício, $19 \%$ possuem formação pós-graduada, enquanto nenhum dos professores readaptados possui este grau de instrução. Contrariamente, $45 \%$ dos professores readaptados têm, 
no máximo, curso superior incompleto, enquanto apenas um professor em exercício (3,0\%) apresentou tal nível de escolaridade. De acordo com os dados da Tabela 4, estas diferenças se mostram estatisticamente significativas.

Tabela 4. Distribuição dos professores entrevistados em relação à escolaridade

\begin{tabular}{lcccccc}
\hline Escolaridade & \multicolumn{2}{c}{$\begin{array}{c}\text { Professores em } \\
\text { exercício }\end{array}$} & \multicolumn{2}{c}{$\begin{array}{c}\text { Professores } \\
\text { readaptados }\end{array}$} & \multicolumn{2}{c}{ Total } \\
\cline { 2 - 7 } & $\mathrm{n}$ & $\%$ & $\mathrm{n}$ & $\%$ & $\mathrm{n}$ & $\%$ \\
\hline Médio completo & 1 & 3,0 & 3 & 27,0 & 4 & 10,0 \\
Sup. incompleto & 0 & - & 2 & 18,0 & 2 & 5,0 \\
Sup. completo & 24 & 77,5 & 6 & 55,0 & 30 & 71,0 \\
Pós-graduação & 6 & 19,5 & 0 & - & 6 & 14,0 \\
\hline Total & 31 & 100,0 & 11 & 100,0 & 42 & 100,0 \\
\hline
\end{tabular}

Qui-quadrado crítico: 7,82 - Qui-quadrado calculado: 9,52 (*)

A distribuição das freqüências relativas ao nível de ensino em que o professor atua ou atuava antes da readaptação não evidenciou qualquer diferença significativa, conforme podemos observar na Tabela 5 .

Tabela 5. Distribuição dos professores entrevistados em relação ao nível de ensino em que atuam ou atuavam

\begin{tabular}{lcccccc}
\hline Nivel de ensino & \multicolumn{2}{c}{$\begin{array}{c}\text { Professores em } \\
\text { exercício }\end{array}$} & \multicolumn{2}{c}{$\begin{array}{c}\text { Professores } \\
\text { readaptados }\end{array}$} & \multicolumn{2}{c}{ Total } \\
\cline { 2 - 7 } & $\mathrm{n}$ & $\%$ & $\mathrm{n}$ & $\%$ & $\mathrm{n}$ & $\%$ \\
\hline Infantil & 15 & 48,0 & 7 & 64,0 & 22 & 52,0 \\
Fundamental & 16 & 52,0 & 4 & 36,0 & 20 & 48,0 \\
\hline Total & 31 & 100,0 & 11 & 100,0 & 42 & 100,0 \\
\hline
\end{tabular}

Qui-quadrado crítico: 3,84 - Qui-quadrado calculado: 1,51 (n.s.) 
Quanto ao número de alunos por classe, os dados da Tabela 6 indicam que a grande maioria dos professores trabalha ou trabalhava em classes com 31 a 40 alunos. Embora a diferença entre os grupos estudados não seja significativa, deve-se ressaltar que $36,3 \%$ dos professores readaptados e apenas $6,5 \%$ dos professores em exercícios trabalhavam ou trabalham em classes com mais de 40 alunos.

Tabela 6. Distribuição dos professores entrevistados em relação ao número de alunos em classe de trabalho

\begin{tabular}{lcccccc}
\hline $\begin{array}{l}\text { Número de alunos em } \\
\text { classe }\end{array}$ & \multicolumn{2}{c}{$\begin{array}{c}\text { Professores em } \\
\text { exercício }\end{array}$} & \multicolumn{2}{c}{$\begin{array}{c}\text { Professores } \\
\text { readaptados }\end{array}$} & \multicolumn{2}{c}{ Total } \\
\cline { 2 - 7 } & $\mathrm{n}$ & $\%$ & $\mathrm{n}$ & $\%$ & $\mathrm{n}$ & $\%$ \\
\hline$<20$ & 0 & - & 0 & - & 0 & - \\
21 a 30 & 2 & 6,5 & 0 & - & 2 & 4,8 \\
31 a 40 & 27 & 87,0 & 7 & 63,7 & 34 & 80,9 \\
$>41$ & 2 & 6,5 & 4 & 36,3 & 6 & 14,3 \\
\hline Total & 31 & 100,0 & 11 & 100,0 & 42 & 100,0 \\
\hline
\end{tabular}

Qui-quadrado crítico: 7,82 - Qui-quadrado calculado: 6,78 (n.s.)

Mostra-se bastante similar a distribuição dos professores entrevistados com relação à jornada semanal de trabalho, sem qualquer diferença importante entre aqueles em exercício e os readaptados, conforme os dados da Tabela 7. Note-se, contudo, que em ambos os grupos é alto o percentual de profissionais cuja jornada de trabalho ultrapassa 40 horas semanais $(28,6 \%$ do grupo geral). 
Tabela 7. Distribuição dos professores entrevistados em relação à jornada semanal de trabalho

\begin{tabular}{lcccccc}
\hline $\begin{array}{l}\text { Jornada semanal de } \\
\text { trabalho }\end{array}$ & \multicolumn{2}{c}{$\begin{array}{c}\text { Professores em } \\
\text { exercício }\end{array}$} & \multicolumn{2}{c}{$\begin{array}{c}\text { Professores } \\
\text { readaptados }\end{array}$} & \multicolumn{3}{c}{ Total } \\
\cline { 2 - 7 } & $\mathrm{n}$ & $\%$ & $\mathrm{n}$ & $\%$ & $\mathrm{n}$ & $\%$ \\
\hline 10 a 20 horas & 1 & 3,2 & 0 & - & 1 & 2,4 \\
21 a 30 horas & 7 & 22,6 & 3 & 27,4 & 10 & 23,8 \\
31 a 40 horas & 15 & 48,4 & 4 & 36,3 & 19 & 45,2 \\
$>40$ horas & 8 & 25,8 & 4 & 36,3 & 12 & 28,6 \\
\hline Total & 31 & 100,0 & 11 & 100,0 & 42 & 100,0 \\
\hline
\end{tabular}

Qui-quadrado crítico: 7,82 - Qui-quadrado calculado: 2,49 (n.s.)

A maioria dos professores em exercício $(77,4 \%)$ e readaptados $(54,5 \%)$ declararam possuir autonomia no trabalho, e a comparação entre os grupos não evidenciou qualquer diferença estatisticamente importante entre os grupos (Tabela 8). Note-se, contudo, a inversão das freqüências distribuídas nos grupos: o percentual dos professores readaptados que declararam autonomia no trabalho $(54,7 \%)$ foi menor do que o dos professores em exercício $(77,4 \%)$, enquanto, inversamente, a falta de autonomia foi maior entre os readaptados $(45,4 \%)$ do que entre os em exercício $(22,6 \%)$.

Tabela 8. Distribuição dos professores entrevistados em relação à autonomia no trabalho

\begin{tabular}{lcccccc}
\hline $\begin{array}{l}\text { Autonomia no } \\
\text { trabalho }\end{array}$ & \multicolumn{2}{c}{$\begin{array}{c}\text { Professores em } \\
\text { exercício }\end{array}$} & \multicolumn{2}{c}{$\begin{array}{l}\text { Professores } \\
\text { readaptados }\end{array}$} & \multicolumn{2}{c}{ Total } \\
\cline { 2 - 8 } & $\mathrm{n}$ & $\%$ & $\mathrm{n}$ & $\%$ & $\mathrm{n}$ & $\%$ \\
\hline Sim & 24 & 77,4 & 6 & 54,5 & 30 & 71,4 \\
Não & 7 & 22,6 & 5 & 45,4 & 12 & 28,6 \\
\hline Total & 31 & 100,0 & 11 & 100,0 & 42 & 100,0 \\
\hline
\end{tabular}

Qui-quadrado crítico: 3,84 - Qui-quadrado calculado: 1,09 (n.s.) 
Metade da amostra total estudada classificou o ambiente de trabalho como estressante, e a comparação estatística entre os professores em exercício e os readaptados não revelou diferença significativa nesta variável (Tabela 9).

Tabela 9. Distribuição dos professores entrevistados em relação ao ambiente de trabalho

\begin{tabular}{lcccccc}
\hline Ambiente de trabalho & \multicolumn{2}{c}{$\begin{array}{c}\text { Professores em } \\
\text { exercício }\end{array}$} & \multicolumn{2}{c}{$\begin{array}{c}\text { Professores } \\
\text { readaptados }\end{array}$} & \multicolumn{2}{c}{ Total } \\
\cline { 2 - 7 } & $\mathrm{n}$ & $\%$ & $\mathrm{n}$ & $\%$ & $\mathrm{n}$ & $\%$ \\
\hline Calmo & 3 & 9,0 & 0 & - & 3 & 7,1 \\
Moderado & 14 & 45,5 & 4 & 36,4 & 18 & 42,9 \\
Estressante & 14 & 45,5 & 7 & 63,6 & 21 & 50,0 \\
\hline Total & 31 & 100,0 & 11 & 100,0 & 42 & 100,0 \\
\hline
\end{tabular}

Qui-quadrado crítico: 5,99 - Qui-quadrado calculado: 2,49 (n.s.)

A grande maioria dos professores entrevistados $(97,6 \%)$ considera que o número excessivo de alunos em sala de aula promove desgaste, e as freqüências relativas a esta variável foram absolutamente semelhantes nos dois grupos estudados (Tabela 10).

Tabela 10. Distribuição dos professores entrevistados em relação ao desgaste pelo número excessivo de alunos por classe

\begin{tabular}{lcccccc}
\hline Desgaste & \multicolumn{2}{c}{$\begin{array}{c}\text { Professores em } \\
\text { exercício }\end{array}$} & \multicolumn{2}{c}{$\begin{array}{c}\text { Professores } \\
\text { readaptados }\end{array}$} & \multicolumn{2}{c}{ Total } \\
\cline { 2 - 7 } & $\mathrm{n}$ & $\%$ & $\mathrm{n}$ & $\%$ & $\mathrm{n}$ & $\%$ \\
\hline Sim & 30 & 96,8 & 11 & 100,0 & 41 & 97,6 \\
Não & 1 & 3,2 & 0 & - & 1 & 2,4 \\
\hline Total & 31 & 100,0 & 11 & 100,0 & 42 & 100,0 \\
\hline
\end{tabular}

Qui-quadrado crítico: 3,84 - Qui-quadrado calculado: 0,33 (n.s.) 
Com relação ao fato de os professores considerarem ou não o trabalho em sala de aula repetitivo, os dados da Tabela 11 mostram que, novamente, não houve diferença entre os grupos estudados nesta variável, refletindo, na amostra geral, que cerca de metade dos entrevistados consideram o trabalho que exercem repetitivo, e a outra metade, não.

Tabela 11. Distribuição dos professores entrevistados em relação ao trabalho repetitivo

\begin{tabular}{lcccccc}
\hline Trabalho repetitivo & \multicolumn{2}{c}{$\begin{array}{c}\text { Professores em } \\
\text { exercício }\end{array}$} & \multicolumn{2}{c}{$\begin{array}{c}\text { Professores } \\
\text { readaptados }\end{array}$} & \multicolumn{2}{c}{ Total } \\
\cline { 2 - 7 } & $\mathrm{n}$ & $\%$ & $\mathrm{n}$ & $\%$ & $\mathrm{n}$ & $\%$ \\
\hline Sim & 16 & 51,6 & 6 & 54,5 & 22 & 52,4 \\
Não & 15 & 48,4 & 5 & 45,4 & 20 & 47,6 \\
\hline Total & 31 & 100,0 & 11 & 100,0 & 42 & 100,0 \\
\hline
\end{tabular}

Qui-quadrado crítico: 3,84 - Qui-quadrado calculado: 0,28 (n.s.)

As freqüências percentuais de professores em exercício $(71,0 \%)$ e dos readaptados $(82,0 \%)$ que consideram o trabalho que exercem cansativo se revelaram semelhantes à estatística (Tabela 12), não registrando diferença significativa entre os grupos estudados, nesta variável, como fator de agravo à saúde do professor, pelo menos quando consideramos o grupo de professores readaptados como o grupo potencial para revelação de eventual fator de agravo à saúde. 
Tabela 12. Distribuição dos professores entrevistados em relação ao trabalho cansativo

\begin{tabular}{lcccccc}
\hline Trabalho cansativo & \multicolumn{2}{c}{$\begin{array}{c}\text { Professores em } \\
\text { exercício }\end{array}$} & \multicolumn{2}{c}{$\begin{array}{c}\text { Professores } \\
\text { readaptados }\end{array}$} & \multicolumn{2}{c}{ Total } \\
\cline { 2 - 7 } & $\mathrm{n}$ & $\%$ & $\mathrm{n}$ & $\%$ & $\mathrm{n}$ & $\%$ \\
\hline Sim & 22 & 71,0 & 9 & 82,0 & 31 & 74,0 \\
Não & 9 & 29,0 & 2 & 18,0 & 11 & 26,0 \\
\hline Total & 31 & 100,0 & 11 & 100,0 & 42 & 100,0 \\
\hline
\end{tabular}

Qui-quadrado crítico: 3,84 - Qui-quadrado calculado: 1,23 (n.s.)

Quando indagados sobre situações de violência ocorridas nas escolas em que trabalham, as situações comumente citadas, por ambos os grupos estudados, foram: indisciplina em sala de aula; roubo de material escolar; ameaças e insultos ao professor pelo aluno; violência à porta da escola e pichações.

Não houve diferença entre as respostas de professores em exercício e readaptados mediante a indagação sobre se mudanças freqüentes e desvalorização profissional interfeririam na motivação para o trabalho. A maioria dos entrevistados considerou tais fatores prejudiciais para a motivação ao trabalho (Tabela 13).

Tabela 13. Distribuição dos professores entrevistados em relação ao fato de mudanças freqüentes e desvalorização profissional interferirem na motivação para o trabalho

\begin{tabular}{lcccccc}
\hline Prejuízo à motivação & \multicolumn{2}{c}{$\begin{array}{c}\text { Professores em } \\
\text { exercício }\end{array}$} & \multicolumn{2}{c}{$\begin{array}{l}\text { Professores } \\
\text { readaptados }\end{array}$} & \multicolumn{2}{c}{ Total } \\
\cline { 2 - 7 } & $\mathrm{n}$ & $\%$ & $\mathrm{n}$ & $\%$ & $\mathrm{n}$ & $\%$ \\
\hline Sim & 26 & 83,8 & 9 & 81,8 & 35 & 83,3 \\
Não & 6 & 16,2 & 2 & 18,2 & 7 & 16,7 \\
\hline Total & 31 & 100,0 & 11 & 100,0 & 42 & 100,0 \\
\hline
\end{tabular}

Qui-quadrado crítico: 3,84 - Qui-quadrado calculado: 0,27 (n.s.) 
Embora os cálculos estatísticos não tenham evidenciado diferença significativa nas respostas dos entrevistados, quando comparados os professores em exercício com os readaptados mediante a questão de concordarem ou não com o fato de serem responsáveis pelo fracasso dos alunos (Tabela 14), há que se notar que $63,6 \%$ dos readaptados não concordam com tal afirmação, contra 45,2\% dos professores em exercício.

Tabela 14. Distribuição dos professores entrevistados em relação à concordância com o fato de o professor ser responsável pelo fracasso dos alunos

\begin{tabular}{lcccccc}
\hline Posição do professor & \multicolumn{2}{c}{$\begin{array}{c}\text { Professores em } \\
\text { exercício }\end{array}$} & \multicolumn{2}{c}{$\begin{array}{c}\text { Professores } \\
\text { readaptados }\end{array}$} & \multicolumn{2}{c}{ Total } \\
\cline { 2 - 8 } & $\mathrm{n}$ & $\%$ & $\mathrm{n}$ & $\%$ & $\mathrm{n}$ & $\%$ \\
\hline Concorda & 17 & 54,8 & 4 & 36,4 & 21 & 50,0 \\
Não concorda & 14 & 45,2 & 7 & 63,6 & 21 & 50,0 \\
\hline Total & 31 & 100,0 & 11 & 100,0 & 42 & 100,0 \\
\hline
\end{tabular}

Qui-quadrado crítico: 3,84 - Qui-quadrado calculado: 0,48 (n.s.)

Foi comum a todos os professores entrevistados mencionar as mudanças contínuas nas políticas educacionais e nas propostas pedagógicas sem preparo prévio para colocá-las em prática como as principais causas de angústias e ansiedades. Declararam, ainda, que esta situação lhes causa inseguranças que resultam em estresse, com todas as suas repercussões na saúde. Uma segunda causa comumente citada referiu-se à falta de tempo para reciclagem e atualização de seus conhecimentos e para novas aprendizagens.

As respostas à indagação sobre se a baixa realização profissional e o fato de não conseguir atingir objetivos propostos trariam ao professor sentimento de impotência capaz de interferir em sua saúde e bem-estar foram exatamente as 
mesmas para os professores em exercício e os readaptados, refletindo, na amostra geral, que $90,0 \%$ consideram estes fatores prejudiciais à saúde e bem-estar (Tabela 15).

Tabela 15. Distribuição dos professores entrevistados em relação ao fato de baixa realização no trabalho e não atingir objetivos propostos interferirem em sua saúde e bem-estar

\begin{tabular}{lcccccc}
\hline Interferência & \multicolumn{2}{c}{$\begin{array}{c}\text { Professores em } \\
\text { exercício }\end{array}$} & \multicolumn{2}{c}{$\begin{array}{c}\text { Professores } \\
\text { readaptados }\end{array}$} & \multicolumn{2}{c}{ Total } \\
\cline { 2 - 7 } & $\mathbf{n}$ & $\%$ & $\mathbf{n}$ & $\%$ & $\mathrm{n}$ & $\%$ \\
\hline Sim & 28 & 90,0 & 10 & 90,0 & 38 & 90,0 \\
Não & 3 & 10,0 & 1 & 10,0 & 4 & 10,0 \\
\hline Total & 31 & 100,0 & 11 & 100,0 & 42 & 100,0 \\
\hline
\end{tabular}

Qui-quadrado crítico: 3,84 - Qui-quadrado calculado: 0,00 (n.s.)

Foi do mesmo modo praticamente unânime a posição, tanto dos professores em exercício, como dos readaptados, quanto à interferência que fatores organizacionais do ambiente de trabalho exercem sobre a sua vida pessoal e sobre a sua saúde (Tabela 16).

Tabela 16. Distribuição dos professores entrevistados em relação ao fato de fatores organizacionais do ambiente de trabalho interferirem em sua vida pessoal e saúde

\begin{tabular}{lcccccc}
\hline Interferência & \multicolumn{2}{c}{$\begin{array}{c}\text { Professores em } \\
\text { exercício }\end{array}$} & \multicolumn{2}{c}{$\begin{array}{c}\text { Professores } \\
\text { readaptados }\end{array}$} & \multicolumn{2}{c}{ Total } \\
\cline { 2 - 8 } & $\mathrm{n}$ & $\%$ & $\mathrm{n}$ & $\%$ & $\mathrm{n}$ & $\%$ \\
\hline Sim & 29 & 93,0 & 11 & 100,0 & 40 & 95,2 \\
Não & 2 & 7,0 & 0 & - & 2 & 4,8 \\
\hline Total & 31 & 100,0 & 11 & 100,0 & 42 & 100,0 \\
\hline
\end{tabular}

Qui-quadrado crítico: 3,84 - Qui-quadrado calculado: 0,00 (n.s.) 
Praticamente todos os professores entrevistados (exceção de dois professores em exercício) declararam estarem insatisfeitos com a remuneração percebida (Tabela 17).

Tabela 17. Distribuição dos professores entrevistados em relação à satisfação com a remuneração

\begin{tabular}{lcccccc}
\hline $\begin{array}{l}\text { Satisfação com a } \\
\text { remuneração }\end{array}$ & \multicolumn{2}{c}{$\begin{array}{c}\text { Professores em } \\
\text { exercício }\end{array}$} & \multicolumn{2}{c}{$\begin{array}{c}\text { Professores } \\
\text { readaptados }\end{array}$} & \multicolumn{2}{c}{ Total } \\
\cline { 2 - 7 } & $\mathrm{n}$ & $\%$ & $\mathrm{n}$ & $\%$ & $\mathrm{n}$ & $\%$ \\
\hline Sim & 2 & 6,5 & 0 & - & 2 & 4,8 \\
Não & 29 & 93,5 & 11 & 100,0 & 40 & 95,2 \\
\hline Total & 31 & 100,0 & 11 & 100,0 & 42 & 100,0 \\
\hline
\end{tabular}

Qui-quadrado crítico: 3,84 - Qui-quadrado calculado: 0,00 (n.s.)

Paradoxalmente aos dados acima apresentados, 100,0\% dos professores em exercício e $80,0 \%$ dos readaptados declararam-se satisfeitos no desempenho das funções atuais, freqüências essas que se revelam similares à análise estatística (Tabela 18).

Tabela 18. Distribuição dos professores entrevistados em relação à satisfação no desempenho de suas funções atuais

\begin{tabular}{lcccccc}
\hline $\begin{array}{l}\text { Satisfação nas funções } \\
\text { atuais }\end{array}$ & \multicolumn{2}{c}{$\begin{array}{c}\text { Professores em } \\
\text { exercício }\end{array}$} & \multicolumn{2}{c}{$\begin{array}{c}\text { Professores } \\
\text { readaptados }\end{array}$} & \multicolumn{2}{c}{ Total } \\
\cline { 2 - 7 } & $\mathrm{n}$ & $\%$ & $\mathrm{n}$ & $\%$ & $\mathrm{n}$ & $\%$ \\
\hline Sim & 31 & 100,0 & 9 & 80,0 & 40 & 95,2 \\
Não & 0 & - & 2 & 20,0 & 2 & 4,8 \\
\hline Total & 31 & 100,0 & 11 & 100,0 & 42 & 100,0 \\
\hline
\end{tabular}

Qui-quadrado crítico: 3,84 - Qui-quadrado calculado: 2,52 (n.s.) 
Todos os professores, tanto em exercício (100,0\%) quanto readaptados $(100,0)$, concordam com a necessidade de se respeitarem duas condições básicas para a atuação eficiente: condições de vida saudável e formação e educação contínuas.

Os mesmos resultados foram observados quando se perguntou a ambos os grupos de professores (em exercício e readaptados) sobre a sua concordância (100,0\% concordantes) com o fato de ter ocorrido substancial transferência de responsabilidades, por parte da comunidade social e da família, para a escola, sem que tal transferência de responsabilidades tenha se acompanhado das mudanças necessárias na formação dos educadores.

$\mathrm{Na}$ Tabela 19 podemos observar que apenas dois professores em exercício (representando $4,7 \%$ da amostra total) não concordam com o fato de a sociedade simplificar os males da escola pública, quando considera os professores responsáveis universais por tudo o que nela possa haver de errado, ainda quando se trate de problemas em que a responsabilidade real do professor e a sua capacidade para evitá-los são muito limitadas.

Tabela 19. Distribuição dos professores entrevistados em relação à concordância com o fato de a sociedade simplificar os males da escola pública e responsabilizá-los pelo fracasso

\begin{tabular}{lcccccc}
\hline Posição do professor & \multicolumn{2}{c}{$\begin{array}{c}\text { Professores em } \\
\text { exercício }\end{array}$} & \multicolumn{2}{c}{$\begin{array}{c}\text { Professores } \\
\text { readaptados }\end{array}$} & \multicolumn{2}{c}{ Total } \\
\cline { 2 - 7 } & $\mathrm{n}$ & $\%$ & $\mathrm{n}$ & $\%$ & $\mathrm{n}$ & $\%$ \\
\hline Concordante & 29 & 93,5 & 11 & 100,0 & 40 & 95,2 \\
Não concordante & 2 & 6,5 & 0 & - & 2 & 4,8 \\
\hline Total & 31 & 100,0 & 11 & 100,0 & 42 & 100,0 \\
\hline
\end{tabular}

Qui-quadrado crítico: 3,84 - Qui-quadrado calculado: 0,00 (n.s.) 
Com relação às situações desgastantes causadoras de sofrimento e insatisfação, foram comuns os seguintes relatos: superlotação das salas de aula; baixa remuneração; falta de reconhecimento da profissão pela sociedade (incluindo a família do aluno, a mídia e as autoridades responsáveis pelo ensino); a falta de limites dos alunos e suas atitudes responsivas inadequadas ao ambiente; e a transferência de responsabilidades extra-docentes. Especificamente com relação aos professores do ensino fundamental, a grande maioria deles citou o fato de não conseguirem levar o aluno a se interessar pela aprendizagem como situação extremamente desgastante.

Ao responderem sobre ao que atribuem o aumento do número de professores readaptados, novamente enfatizaram o estresse causado pelo excesso de alunos em sala de aula; a desvalorização da profissão docente; a baixa remuneração que enseja jornadas extensas de trabalho que, por sua vez, impedem horários adequados para alimentação saudável e atividades de descanso e lazer.

Por fim, a questão respondida apenas pelos professores readaptados sobre os motivos que os levaram à readaptação indicou o estresse (inclusive como causa de hipertensão e outros problemas de saúde), o cansaço físico e mental e problemas de voz e audição. A maioria deles se sentiu "lembrada" com a realização desta pesquisa, que lhes permitiu se expressar sobre as suas angústias, satisfações e insatisfações na profissão docente.

\subsection{Síntese dos resultados}

Ao considerarmos o grupo de professores readaptados como 
representantes dos eventuais indicadores de agravos à saúde do professor da escola pública municipal de São Paulo, nossas observações quantitativas e objetivas revelaram que o tempo prolongado de exercício no magistério, nas condições e na forma em que hoje é realizado o trabalho docente e o déficit na formação profissional, em relação às demandas do ensino, constituem fatores significativos de agravo à saúde do professor. Os resultados mostram, estatisticamente, que a desqualificação profissional do professor - seja por questões de formação, ou motivada por freqüentes mudanças na política, nas diretrizes, nas propostas educacionais, Tabela 2 e Tabela 4 - frente às demandas atuais do ensino, e a atuação prolongada sob o efeito de extressores, conforme referenciados no estudo, podem levar os docentes à readaptação, com probabilidade de essas ocorrências alcançarem grande parcela de professores da rede municipal de ensino de São Paulo.

Considerando que as condições econômicas e sociais, mesmo fora do local de trabalho, nele têm repercussões, nesta mesma linha de análise, verificamos tendência estatística importante de o estado civil do profissional educador interferir na saúde e bem-estar, porquanto verificou-se maior número de readaptações entre os professores divorciados.

Sugerindo ajuizamento denunciativo, o número excessivo de alunos em sala de aula e a insuficiência da remuneração percebida pelos professores, em conformidade com a intensidade de freqüência em que apareceram na pesquisa, podem ser classificados entre os maiores indicadores de agravos à saúde e bem-estar.

Quanto à complexidade da profissão docente, nossos dados revelaram que quase a totalidade dos professores entrevistados (independentemente de estarem em exercício ou readaptados) declarou que: 
- o número excessivo de alunos em sala de aula torna estressante o trabalho educativo;

- o trabalho docente, nas condições em que é exercido, conforme contexto evidenciado na pesquisa, é cansativo e desgastante;

- as mudanças freqüentes de política e de propostas educacionais redigidas à margem dos professores, bem como a "opinião pública" depreciativa da profissão docente desmotivam a ação dos educadores;

- o baixo nível de realização profissional (representado pelo fraco desempenho dos alunos), os fatores organizacionais do ambiente de trabalho, as jornadas extenuantes, a insatisfação com a remuneração salarial, a falta de atendimento às condições básicas de trabalho, a transferência de responsabilidades sociais e da família para a escola pública (para as quais o professor não recebeu formação para atuar com competência) interferem na vida pessoal, no bem-estar e na saúde dos professores.

Paradoxalmente, a maioria dos entrevistados, em exercício ou em readaptação, declarou sentir satisfação no desempenho da atividade docente.

As questões de absenteísmo e readaptações não decorrentes de agravos à saúde, não fazem parte dos temas abordados nesta discussão porque alheias aos objetivos e porque a apreciação dessas questões demanda análise da estrutura administrativa do Departamento de Saúde dos Trabalhadores - DESAT, da Secretaria Municipal de Saúde que, no caso, não consta das propostas de pesquisa. 


\section{DISCUSSÃO}

\subsection{Dados amostrais}

A proposta deste estudo exploratório, cujos dados receberam tratamento qualitativo e quantitativo, buscou dar início a reflexões que possam ser aprofundadas sobre os agravos à saúde dos professores de escola pública do município de São Paulo e, conseqüentemente, sobre a complexidade da profissão docente.

Para tanto, aplicamos questionário cuidadosamente formulado com questões fechadas e abertas a 42 professores lotados em escolas pertencentes às Coordenadorias da Lapa, Pirituba e Perus, da Secretaria de Educação do Município de São Paulo, dos quais $31(74,0 \%)$ estão em exercício e 11 (26,0\%), readaptados.

Estabelecemos o grupo de professores readaptados como parâmetro para as nossas análises quantitativas, já que inferimos que suas respostas refletiriam o percurso que os levaram à readaptação. E neste sentido, foi importante conhecer o agrupamento das principais restrições constantes dos Laudos Médicos referentes a esses servidores, que transcrevemos a seguir:

A. não deverá exercer atividades que exijam o uso contínuo e obrigatório da voz;

B. não deverá exercer atividades que exijam deambulação constante (subir e 
descer escadas com freqüência); permanência em pé por tempo prolongado; uso de força, habilidade ou movimentos repetitivos com o membro superior (esquerdo/direito);

C. não deverá exercer atividades intra ou extra-classe, devendo permanecer, sob supervisão direta, em período diurno e ambiente não gerador de tensão emocional. Poderá apenas exercer atividades sem risco para si ou terceiros, em ambiente interno, calmo e não sujeito a tensão emocional;

E. poderá apenas exercer atividades que não exijam contato com irritantes, como pós, poeira ou mofo, em ambiente ventilado.

Assim, os professores readaptados exercem, atualmente, atendimento ao público e/ou serviços operacionais, alguns exercem funções na secretaria das escolas, ressaltando-se que os motivos da readaptação os mantêm distanciados da atividade docente propriamente dita, profissão pela qual optaram.

Embora nossos dados tenham revelado predomínio do sexo feminino $(86,0 \%)$ da amostra como um todo, não houve diferença entre os professores em exercício e os readaptados em relação ao sexo. De fato, a população que trabalha em escolas de ensino básico, especialmente em educação infantil e ensino fundamental, é majoritariamente composta de um público feminino. Trata-se, inclusive, de um fenômeno sociocultural ocorrido e estabelecido já há alguns anos, e nossa amostra acaba sendo nada além do que o reflexo dessa realidade. Além disso, o fato de termos acolhido entrevistados voluntários, pelas razões expostas no capítulo sobre a metodologia do estudo, não permitiu a construção de uma amostra probabilística, e essa sim nos mostraria mais fidedignamente se a variável sexo teria alguma influência sobre os propósitos deste trabalho. Deste modo, nossas considerações não 
poderão se estender para todo o universo de docentes, mas estarão refletindo nossos achados no grupo estudado.

Muitos aspectos sobre os quais refletimos ao longo desta discussão, inclusive, parecem poder explicitar a razão pela qual a mulher - ainda considerada secundária na ordem social no que se refere ao plano profissional e econômico (DEL PRIORI, 2000) - acaba sendo o sujeito docente nos ciclos escolares iniciais.

Foi estatisticamente significativo o fato de todos os professores readaptados estarem na faixa etária superior à dos professores em exercício. Se tomarmos este dado como descritivo de uma realidade, encontramos aqui o primeiro dado objetivo sobre os agravos à saúde do professor: tempo de serviço. E deste dado pode-se especular sobre a implicação do tempo de exercício da atividade docente.

Impõe-se a questão sobre o tempo em que um professor pode permanecer submetido à demanda emocional exigida pela docência, o que levaria, então, a Administração Pública a repensar as recentes alterações introduzidas na legislação que dispõe sobre o tempo necessário à aposentadoria do professor, segundo as quais o tempo de exercício necessário para o direito à aposentadoria passou a ser ainda maior do que era antes.

Nesta linha de pensamento, a readaptação - com todas as implicações que este estado profissional acarreta à vocação docente - constituiria uma espécie de "período de pré-aposentadoria compulsória".

Como vimos, estes professores readaptados estão exercendo funções operacionais e/ou administrativas que fogem de sua vocação docente. Até chegar o momento em que gozarão do direito à aposentadoria, estarão nessas funções distantes da docência (atividade profissional pela qual optaram), muitas vezes sujeitos ao 
desdém, velado ou escancarado, dos colegas em exercício. Chegamos ao ponto de inferir que, se todos os aspectos que abordamos nesta discussão, por si só, podem consistir em agravos à saúde do professor, o docente já readaptado (ou seja, já afastado das tarefas principais por problemas de saúde) permanece sob uma condição estressante que, via de regra, só tende a agravar o seu estado de saúde.

Merece ser transcrito, neste ponto, o depoimento de um professor readaptado de educação infantil: “... após 32 anos de trabalho dedicado à educação e à vida escolar, com total envolvimento emocional, estou com a saúde abalada por problemas cardíacos, tendo sido readaptado pelo período de um ano, renovado agora por mais dois anos e, ao que tudo indica, deverei aposentar-me sem retornar às atividades normais. Esse foi o prêmio recebido por todos esses anos de trabalho".

Com relação ao estado civil, não houve diferenças significativas entre professores em exercício e readaptados. Todavia, o fato de $36 \%$ dos readaptados serem divorciados, contra $3 \%$ dos professores em exercício, permite levantar a hipótese de que situações pessoais e familiares insatisfatórias poderiam ser causa ou efeito da satisfação que se tem com a atuação profissional. Não adentraremos nesta questão, todavia, por não estar diretamente focalizada pelos objetivos deste estudo, e até porque o extrapolaria. Preferimos entender que se trata de achado descritivo aleatório, sobre o qual nenhuma menção encontramos na literatura adotada para a fundamentação desta pesquisa.

Outro achado estatisticamente significativo refere-se ao fato de $19 \%$ dos professores em exercício possuírem formação pós-graduada, enquanto nenhum dos professores readaptados possui este grau de instrução. Por outro lado, $45 \%$ dos readaptados têm, no máximo, curso superior incompleto, nível de escolaridade 
encontrado em apenas um professor em exercício $(3,0 \%)$.

A primeira reflexão sobre este resultado nos remete a DEJOURS (1997), para quem o sucesso ou o fracasso de uma tarefa obrigatória estão diretamente relacionados ao nível de qualificação e, conseqüentemente, à adaptação do conteúdo da tarefa às competências reais do trabalhador. Segundo esse autor, o nível de qualificação (...) não é, via de regra, suficiente em relação às aspirações, mas o bloqueio da evolução dessa relação ensejaria o início do sofrimento.

Parece-nos, aqui, que o tema é muito mais complexo do que aparenta. É fato que, quanto maior a formação acadêmica, mais condições se têm para tentar se compreender o entorno de nossas atuações. Por outro lado, a velocidade com que se espalham novos meios de informação e de formação enseja meios igualmente novos para a qualificação do docente. Trata-se, aqui, do que DEJOURS denomina de conteúdo significativo do trabalho. Não mais se espera do professor que ele seja mero instrumento de informação acadêmica. Por outro lado, não se dá ao pretenso professor condições de se qualificar para atuar além da condição informativa.

Ao longo desta discussão, verificamos o quanto é desgastante para o professor estar a par da multiplicidade de teorias e trabalhar as diferentes estratégias implícitas nas abordagens pedagógico-educacionais disponíveis.

Resta, assim, a intrigante questão sobre qual seria, então, o grau de formação e de qualificação para o professor de ensino básico, que lhe permitisse sentir-se no controle de suas tarefas.

A Organização Internacional do Trabalho (OIT) constitui, no seio das Nações Unidas, o quadro institucional que se esforça em assegurar que os direitos humanos fundamentais dos trabalhadores (qualquer que seja sua categoria 
profissional) sejam universalmente respeitados, e que suas condições de trabalho sejam permanentemente melhoradas, sobretudo face ao desafio das novas tecnologias e da globalização que modificaram radicalmente as circunstâncias concretas do trabalho humano.

Nesse contexto, um aspecto importante tem a ver com a lógica de mercado que se apoderou da instituição escolar. Conceitos como valores, cultura, cidadania, foram substituídos por análise custo-beneficio, critérios de desempenho, eficácia, produção a baixo custo, elementos descartáveis, estruturas administrativas. Assim, a educação e o ensino estão cada vez mais dominados pelas regras de competição econômica dos diferentes países, e, por vezes, temos dúvidas se os estudos sobre cognição e aprendizagem, inovação pedagógica, desenvolvimento do raciocínio formal, aprender a aprender, criação de técnicas e tecnologias educativas potencializadoras da aprendizagem, não serão instrumentos para prestação de serviços de uma nova geração de mão de obra qualificada, mas não de seres humanos mais equilibrados, perfeitos e felizes.

De qualquer forma, para que as condições de trabalho dos educadores sejam respeitadas, como preconiza a OIT, a formação desses educadores deve lhes proporcionar condições de responder adequadamente às circunstâncias concretas do processo de trabalho docente.

Nesse sentido, o Parecer 009/2001, do Conselho Nacional de Educação, apreciando proposta de Diretrizes para a formação de professores da Educação Básica, em cursos de nível superior, formulada para este fim, seriamente critica os cursos de formação existentes, pontuando lapsos e indicando caminhos de acertos que devem ser urgentemente colocados em prática. 
Por outro lado, a análise das propostas de formação desses cursos indica que muitos programas de formação de professores são orientados, ainda hoje, por um modelo de professor "eficaz" ou "bom". Tal modelo, na maioria das vezes implícito, agrupa o conjunto de qualidades atribuídas ao bom professor em uma sociedade e em um momento histórico determinados.

Ocorre que os modelos normativos de formação de professores ainda perduram, apesar do desenvolvimento contrário de pesquisas realizadas nos últimos anos. Se assim acontece é porque se sustentam em uma simplificação generalizada da realidade, negada pelas pesquisas, mas profundamente arraigada na imagem social do professor: a existência de denominadores comuns nos traços de personalidade dos “bons professores". De fato, como assinala ESTEVE (1999), a conduta do professor é considerada como um reflexo da sua personalidade. Assim, acredita-se que os bons professores o são não pela forma em que atuam, mas pelo que pessoalmente são, já que se aplica uma teoria que considera a personalidade como um conjunto de traços que configuram o comportamento.

Interessa destacar que a sobrevivência de tais modelos na formação inicial tem efeitos negativos sobre a personalidade dos professores, constituindo uma importante fonte de ansiedade em sua atividade profissional.

Esses enfoques normativos implicam a suposição de que o professor é o único e pessoalmente responsável pela eficácia docente, já que se estabelece uma relação direta entre a personalidade do professor e o êxito no magistério. Subtendese, portanto, que, se não se obtém êxito no trabalho docente, é porque o professor não serve, porque não é bom professor. 
Formado por esse enfoque normativo, o professor tende a se culpar, a partir dos primeiros enfrentamentos com a realidade cotidiana do magistério, pois, muitas vezes, descobre que sua personalidade tem limitações que não se encaixam no modelo de professor ideal, com o qual se identificou durante o período de formação docente.

A maioria dos professores entra, assim, em um período de crise de identidade profissional. Colocam-se a si mesmos em questão, considerando que não servem para o magistério porque lhes falta alguma das qualidades atribuídas ao professor ideal.

Quando, na formação, se utilizam modelos descritivos, ao constatar um fracasso, o professor sabe que deve corrigir sua atuação estudando a realidade em que trabalha, com o fim de responder adequadamente aos elementos da situação que não domina. Se utilizados modelos normativos, o professor fica bloqueado no reconhecimento de suas limitações, culpando-se por não corresponder ao estereótipo de professor ideal que assumiu e interiorizou como próprio, durante o período da formação inicial e que, por definição, é inatingivel.

A par dos problemas enfrentados pela escola, decorrentes da formação dos professores, as lógicas que orientam a organização do trabalho educativo nem sempre apresentam coerência entre si. A lógica da Secretaria Municipal de Educação nem sempre está em sintonia com a lógica das Unidades Escolares que, por sua vez, pode ser incompatível com os problemas enfrentados no cotidiano escolar.

As Diretorias de Programas Especiais das Coordenadorias de Educação, por exemplo, desenvolvem projetos paralelos, supostamente favorecedores do ensino, nos quais as escolas devem estar envolvidas, o que faz 
sobrecarregar o trabalho dos professores, obrigados a efetuar uma série de outras atividades além das que lhes são normalmente atribuídas.

\subsection{O processo de trabalho}

O nível de ensino em que o professor atua ou atuava antes da readaptação não evidenciou qualquer diferença significativa entre professores em exercício e os readaptados, muito embora a maior freqüência de professores readaptados tenha atuado no nível de educação infantil.

Esta tendência observada ratifica dados levantados do arquivo do Setor de Recursos Humanos da Coordenadoria Regional de Educação de Pirituba, segundo os quais a maior freqüência de professores readaptados advém da educação infantil.

“... acredita-se que são inúmeros os fatores que levam a isso, problemas familiares, situações de desgaste de relacionamento no âmbito de trabalho. Número de crianças em sala de aula; jornadas exageradas de trabalho. Dedicação extrema do professor em sala de aula em relação a tudo. Médicos do DESAT (na época que me readaptei DEMED), me disseram que exigi da minha coluna aquilo que ela não podia dar. Eu gostava de brincar com eles, pular, dançar. Abaixei milhares de vezes para amarrar tênis das crianças, pegava sempre crianças no colo, etc. Cada um tem seus sérios motivos para licenças e readaptações (eu espero), pois foi o que aconteceu comigo nos anos 
de sala de aula, a profissão causou-me sérios problemas de coluna, o que vou carregar até morrer..." (professor de educação infantil, readaptado)

A partir da primeira Lei de Diretrizes e Bases da Educação Nacional, de 1961, houve importante produção doutrinária em torno do conceito de sistema de ensino, que pode ser entendido como o conjunto de elementos materiais ou não que dependem reciprocamente uns dos outros, de maneira a formar um todo organizado.

Pode-se dizer que o sistema escolar é caracterizado como um sistema aberto, que tem por objetivo proporcionar educação. Compreende uma rede de escolas e sua estrutura de sustentação.

Ocorre que na idéia de sistema está implícita a idéia de coesão, o que leva ao entendimento de que sistema de ensino não se refere a conjunto ou rede de escolas, ou de instituições educacionais, mas a conjunto de normas de organização, o que vêm a ser objeto de estudo na presente pesquisa, tendo em vista que podem interferir na realização do trabalho e na qualidade de vida dos educadores.

O Sistema Municipal de Ensino de São Paulo abrange os níveis de ensino fundamental e de educação infantil, cabendo a ele estabelecer normas gerais de funcionamento para as escolas públicas, municipais e particulares, nestes niveis, no âmbito de sua competência.

É dever do Município de São Paulo garantir a educação igualitária, desenvolvendo o espírito crítico em relação a estereótipos de todas as formas. É dever, ainda, garantir a educação infantil para o desenvolvimento integral da criança até seis anos de idade, em seus aspectos físico, psicológico, intelectual e social; o ensino fundamental gratuito a partir de sete anos de idade, ou, para os que a ele não 
tiveram acesso, na idade própria; educação inclusiva que garanta as pré-condições de aprendizagem e acesso aos serviços educacionais; a matrícula no ensino fundamental, a partir dos seis anos de idade, desde que plenamente atendida a demanda a partir dos sete anos.

Como norma do sistema municipal, a educação infantil é destinada às crianças de zero a seis anos e é exercida em creches e escolas de educação infantil, cuja atuação é integrada de modo a garantir os direitos da população infantil. O ensino fundamental destina-se a crianças $e$ jovens $e$ aos que não tiveram oportunidade de acesso à escola, à época oportuna.

No município de São Paulo, a implantação do sistema de ensino tem, como requisitos, a participação conjunta do Poder Público local, da comunidade e dos agentes responsáveis pelo processo educativo - os educadores. Dentro desse processo, cabe às escolas a responsabilidade de elaborar e executar o projeto pedagógico; administrar pessoal e recursos materiais e financeiros; assegurar o cumprimento dos dias letivos e horas-aula estabelecidas; velar pelo cumprimento do plano de trabalho de cada docente; prover meios para a recuperação dos alunos de rendimento insatisfatório; articular-se com as famílias e a comunidade, criando processo de integração da sociedade com a escola; informar os pais e responsáveis sobre a freqüência e o rendimento dos alunos, bem como sobre a execução de sua proposta pedagógica; notificar aos Conselhos Tutelares do Município, ao juiz competente da Comarca e ao respectivo representante do Ministério Público a relação dos alunos que apresentem quantidade de faltas acima de cinqüenta por cento do percentual permitido em lei. 
Nesse contexto de compromissos e responsabilidades, a escola deve formar pessoas para o mercado de trabalho que saibam lidar com as diferentes necessidades do sistema, capazes de entrar em estruturas e delas sair com extrema competência, e não mais estudantes. Esta é uma direção que as escolas, de uma forma ou de outra, devem acatar, já que se trata de uma orientação não só administrativa como também política, uma vez que o processo de globalização assim o exige.

Pelo que se pode deduzir dos relatos de pesquisa, as adequações a essa nova realidade, que propõe mudar a própria função da instituição escolar, não se fazem com a participação ou a anuência dos professores. Estes, por sua vez, levados a cumprir normas e determinações partem, ansiosos, em busca de métodos regeneradores que dêem conta de atingir, o mais eficientemente possível, as necessidades do sistema.

Estudos de fatores psicossociais do trabalho revelam que essas circunstâncias podem interagir com elementos concernentes à vida dos educadores exercendo pressões sobre eles. Diante desse quadro, aparentemente inelutável, imagina-se que o professor seja acometido de inseguranças que vão se tornando cada vez mais cristalizadas com o passar do tempo.

Quanto ao número de alunos por classe, a grande maioria dos professores entrevistados trabalha ou trabalhava em classes com 31 a 40 alunos. Embora a diferença entre os grupos estudados (readaptados e não readaptados) não tenha sido significativa, deve-se ressaltar que $36,3 \%$ dos professores readaptados e apenas $6,5 \%$ dos professores em exercício trabalhavam ou trabalham em classes com mais de 40 alunos. 
Neste sentido, a grande maioria dos professores entrevistados $(97,6 \%)$ considera o número excessivo de alunos em sala de aula como o fator de desgaste mais relevante na atividade docente.

Um aspecto que caracteriza esse problema é a pretensa democratização do ensino - diretriz da Administração Municipal - que coloca maior número de alunos em sala de aula. Chama-se de pretensa porque essa medida não vem acompanhada de condições estruturais capazes de manter, ou criar, a qualidade do ensino. Mais alunos nos bancos escolares não significa, na prática, mais escolas e mais professores, mas sim salas de aula superlotadas, o que, além de comprometer ainda mais o processo de ensino/aprendizagem, leva os professores à fadiga e ao esgotamento, com veremos no decorrer desta reflexão.

A fala dos professores ajuda a visualizar os riscos e conseqüências dessa medida:

“... o aumento de profissionais da educação readaptados está totalmente ligado ao número excessivo de alunos em sala de aula..." (professor de educação infantil, readaptado).

“... ser professor é uma profissão sublime e massacrante, na qual, muitas vezes, se tem que dar mais do que se possui, sem orientação, paciência, pique, porque criança exige muito. As condições são precárias. Quando entrei na Prefeitura larguei uma classe de 12 crianças de $2^{a}$ série para pegar 52 alunos matriculados, de três a quatro anos, numa sala minúscula, onde metade das mesinhas ficavam para fora da sala porque não cabiam na sala. As crianças vinham de fralda, muitas não sabiam o que era 
banheiro. As mesinhas são baixas, de acordo com o tamanho das crianças, $e$ o professor vive curvado e sentando-se em cadeirinhas minúsculas que acabam com as costas. Fora que o professor larga sua casa e seus filhos para ficar horas nas escolas, "cuidando" dos filhos de outras pessoas para poder levar comida para casa." (professor de educação infantil, readaptado).

Estes depoimentos denunciam as condições de trabalho a que são submetidos os professores das escolas públicas do município de São Paulo, sugerindo que essas condições podem afetar-lhes a saúde a ponto de levá-los à readaptação.

\subsection{Condições de trabalho}

Com relação à jornada semanal de trabalho, não houve qualquer diferença importante entre as repostas dos professores em exercício e os readaptados. No entanto, em ambos os grupos foi alto o percentual de profissionais cuja jornada de trabalho ultrapassa 40 horas semanais $(28,6 \%$ do grupo geral).

De depoimentos dos próprios professores retira-se que a jornada de trabalho excessiva não é inerente à profissão docente; é, antes, conseqüência de remuneração questionável pelos serviços prestados:

“... para dar melhores condições de vida à minha família, cheguei a ter três empregos, com 75 aulas semanais, o que me deixava totalmente 
desgastado ao atingir o final de semana..." (professor de ensino fundamental com jornada de quarenta horas semanais).

“... sinto-me cansado, uma vez que é necessário trabalhar muito e em diversas escolas, a fim de conseguir um salário justificável para o padrão de um professor consciente e com dignidade no oficio, tendo sempre que estar atualizado, com o plano em constante mudança, para adaptações ao nivel das classes, sempre trazendo novidades para motivar os alunos e concentrálos no estudo..." (professor de ensino fundamental, com jornada tripla de trabalho semanal).

Dos depoimentos acima pode-se extrair que a sobrecarga de trabalho, em razão das jornadas excessivas, relega os professores a uma dificil condição de vida. As falas enunciam que essas condições fazem do educador um simples cumpridor de jornadas e dias letivos. Não lhes deixam tempo para o exercício da docência necessária aos alunos e ao próprio desenvolvimento profissional.

Há muito tempo, já se tem notícia de que a jornada de trabalho de um professor não é das mais leves, isto é, para ter um salário razoável é preciso que se desdobre em várias frentes de trabalho. Geralmente, dá aulas em pelo menos duas instituições. Um professor da rede pública municipal, por exemplo, chega a trabalhar 76 (setenta e seis) horas-aula semanais. A legislação específica do município permite que o professor acumule, semanalmente, uma jornada integral de 40 (quarenta) horas (JEI), mais uma jornada ampliada de 30 (trinta) horas (JEA) e ainda 6 (seis) horas de trabalho excedente (TEX) para poder participar do Projeto Especial de Ação (PEA), obrigatoriamente desenvolvido nas escolas do município. Percebe-se que a rotina fatigante a que são submetidos os professores os leva a um tipo de cansaço, muitas 
vezes, sinônimo de embotamento intelectual. O pensamento parece manter-se paralisado diante de uma rotina desgastante por si mesma. O inexorável cansaço lhes é, portanto, companheiro inseparável, como atestam os depoimentos dos professores que participaram da pesquisa.

Quando o professor tem que correr de um lado para outro a fim de completar a sua jornada de trabalho, de modo a ter o mínimo de retorno financeiro para o seu sustento, acaba não realizando a contento o próprio trabalho. Trabalhar por longos períodos submetidos a tais condições, pelo que expõem, traz conseqüências sérias tanto para eles quanto para o trabalho. Acaba por comprometer a saúde de ambos.

“... claro que pode afetar a saúde do professor, já que trabalha com muitas classes numerosas o dia todo ou numa mesma escola, ou em diversas, a fim de obter um salário condigno, mais agravado, quando tem necessidade de arrumar aulas à noite em escolas particulares. É mais viajar, deslocando-se de um lado para outro do que parar para refletir. A reflexão, muitas vezes, é feita nesses deslocamentos, quer dirigindo, quer sentado num ônibus ou num trem ou, ainda hoje, num metrô, o que ocasiona sonolência e, deste modo, a reflexão é interrompida. As angústias e ansiedades aceleram-se e há precisão de conseguir pensamentos auxiliares para superá-las e não é muito fácil. Ler, então, nem se fale...". (professor de ensino fundamental readaptado, com jornada tripla de trabalho semanal)

“... insatisfação, frustração, ansiedade, já que muitos têm dupla jornada, mal têm tempo de alimentar-se, muitos com pouco tempo de lazer e remuneração 
que lhe permita uma situação de folga financeira.. ". (professor de educação infantil com jornada de quarenta horas semanais)

Dessa forma, o professor acaba por deixar de lado, obrigatoriamente, uma outra parte intrínseca à profissão, que é a reflexão sobre o processo de ensino/aprendizagem, compondo uma equação nada auspiciosa: muitas aulas, pouco tempo para pensar a qualidade do ensino, pouca ou nenhuma satisfação.

No que diz respeito à relação dos professores com o conteúdo significativo do trabalho, verifica-se que não se sentem agentes responsáveis pelo resultado de suas próprias tarefas pedagógicas: na grande maioria dos depoimentos relacionados com o trabalho diário, não aparece menção ao controle de aproveitamento ou aprendizagem dos alunos.

É que, na forma como as escolas funcionam, os professores não conseguem avaliar de que modo o seu esforço produz aprendizado, ou está influenciando a formação integral de seus alunos, nem percebem reconhecimento algum por parte dos alunos ou de outros integrantes da escola.

Essa impossibilidade de identificar os resultados do seu trabalho os impede de experimentar qualquer tipo de feedback, ou seja, não sabem qual é o significado, ou para que servem suas tarefas.

Ao vivenciar essas circunstâncias, ingressam num ciclo vicioso de insatisfação e queda crescente de desempenho no trabalho. A falta de identificação dos resultados e do conseqüente feedback parece levar os professores a experimentar um sentimento de inutilidade. Como diz DEJOURS (1997): "outra vivência não menos presente do que a da indignidade, o sentimento de inutilidade, remete primeiramente à falta de qualificação e de finalidade no trabalho". 
A questão da autonomia pode ser considerada como um dos aspectos do trabalho cuja falta também foi relacionada ao sofrimento na fala dos componentes da amostra.

Ao identificar a representação social do trabalho penoso para motoristas de ônibus, SATO (1993) obtém que os contextos de trabalho sentidos como penosos são aqueles sobre os quais o trabalhador não tem controle para ajustar as demandas e as atividades. O controle sobre o contexto de trabalho, conforme revela esse autor, é determinado por três elementos: o poder - determinado a partir da estrutura organizacional; a familiaridade - o conhecimento do contexto de trabalho e sobre si mesmo naquele contexto; o limite subjetivo - o grau em que a pessoa suporta tal situação.

A maioria dos professores, tanto em exercício $(77,4 \%)$ quanto os readaptados $(54,5 \%)$, declarou possuir autonomia no trabalho, e a comparação entre os grupos não evidenciou qualquer diferença estatisticamente importante. Todavia, o percentual dos professores readaptados que declararam autonomia no trabalho $(54,7 \%)$ foi menor do que o dos professores em exercício $(77,4 \%)$, enquanto, consistentemente, a falta de autonomia, foi maior entre os readaptados $(45,4 \%)$ do que entre os em exercício $(22,6 \%)$.

Embora se afirme que todo professor tem autonomia para gerir o ensino de sua disciplina, isso parece não aliviar o seu sofrimento. Entende-se que o exercício da autonomia torna exeqüível o princípio da eficiência. Mas os professores percebem, que por mais que se esforcem, não conseguem ser eficientes frente às dificuldades encontradas na execução de suas tarefas, bem porque não possuem, na prática, o controle sobre o processo de trabalho. 
$\mathrm{Na}$ verdade, os professores não têm autonomia para interferir nos procedimentos do trabalho, ainda que, muitas vezes, sejam dotados de experiência suficiente para tanto. Essa impossibilidade de exercer a profissão docente em condições mínimas de satisfação e autonomia cobra do professor o preço caro de sua saúde, não só física, mas também psíquica (KFOURI, 1992)

\subsection{O ambiente escolar}

Metade da amostra total estudada, tanto dos professores em exercício quanto dos readaptados, classificou o ambiente de trabalho como estressante. Esta afirmação foi ainda mais freqüente entre os professores de educação infantil, por um lado, e entre os readaptados, por outro.

Dentre os fatores ambientais estressantes, o mais citado foi o ruído que, muitas vezes, ultrapassa os parâmetros das Normas Regulamentadoras:

“... ambientes barulhentos, muito frios, classes numerosas, cheias de aluno da contra-cultura, que precisavam ser bem trabalhados, bem adaptados ao ambiente escolar (seu novo habitat), ocasionam problemas fisicos, auditivos, na voz, emocionais. Há ambientes forjados pelas concepções administrativas da própria escola, contrários às normas democráticas para uma escola pública, que podem ocasionar decepções a um professor sabedor dos interesses e necessidades populares, proporcionando e, conseqüentemente, aumentando-lhe as afecções...". (professor de ensino fundamental, readaptado). 
“... satisfação no trabalho é quase nula, a não ser pelo gosto no que faço, apesar dos contratempos. Insatisfações são muitas que minam a realização pessoal e causam reflexos no fisico, como, talvez, a minha doença labirintite - que se iniciou com zumbido no ouvido esquerdo, em 1982 e agravou-se em 1986 com surdez quase completa, levando o médico a operálo em 1991 (descompressão do saco endolinfático) e ficando totalmente surdo dele com zumbidos sucessivos, com o consolo do desaparecimento das vertigens e da labirintite, graças a Deus...". (professor de ensino fundamental, readaptado).

Estes depoimentos denunciam que professores são vitimados pelas condições adversas do trabalho docente. Além de ruido excessivo, classes numerosas e jornadas extenuantes podem causar problemas auditivos, de voz e estresse.

Neste estágio, se encaminhados à readaptação, passam a ser considerados inválidos à atividade docente, conforme indicações da pesquisa. Afastados da sala de aula por determinação médica, sentem-se humilhados, inúteis, pois que passam a executar tarefas sem relevância, além de não participarem mais das atividades pedagógicas desenvolvidas na escola.

Com relação ao fato de os professores considerarem ou não o trabalho em sala de aula repetitivo, não houve diferença entre as respostas dos professores em exercício e os readaptados; todavia, metade dos entrevistados considera o trabalho que exerce repetitivo.

Em nossa prática, sabemos que os diretores de escola se manifestam descontentes com o comportamento apresentado pelos docentes que trabalham com crianças de faixa etária mais precoce. Alegam as dificuldades em gerenciar as 
atividades educativas realizadas por esses professores. Argumentam que os professores discutem, choram, sentem mal-estar sempre que é preciso trocar de salas, de armários, de cor dos cadernos, das pastas. Enfim, dizem que esses professores apresentam comportamento infantil, muito semelhante ao dos alunos.

Em que pese essas questões demandarem aprofundamento de estudos, pode-se avaliar o que significa um professor permanecer um quarto de século de sua própria existência, pelo menos meio turno do seu dia de expediente (alguns mais), dialogando, sempre, com interlocutores de uma mesma faixa etária. Um professor de ensino básico, por exemplo, está sujeito a essa atividade repetitiva que, como afirma ESTEVE (1999), é capaz de provocar lesões semelhantes à tendinite dos digitadores, só que em áreas mais nobres do ser, as quais envolvem condições superiores a músculos e ossos. ESTEVE argumenta, ainda, que essa condição do trabalho docente se identifica com elementos constitutivos de sofrimento no trabalho.

As freqüências percentuais de professores em exercício $(71,0 \%)$ e dos readaptados $(82,0 \%)$ que consideram o trabalho que exercem cansativo se revelaram semelhantes à estatística, mas foram maioria em ambos os grupos. Se, por um lado, a similaridade das respostas de ambos os grupos não aponta diferença significativa entre os readaptados e os em exercício, por outro lado revela um sentimento comum que deve ser peculiar à função que exercem, da forma como a exercem.

$\mathrm{O}$ medo também apareceu como um dos elementos constitutivos do sofrimento no trabalho. Medo de adoecer, passar à readaptação e se transformar em "zumbi", que é a forma como o professor readaptado se autodenomina, uma vez que, a partir da readaptação, passa a executar tarefas sem significância. 
Os professores sentem medo que o processo de readaptação, que os invalida às atividades docentes, interdite o direito à aposentadoria especial, obrigando-os a prorrogar, por mais cinco anos, o tempo de serviço.

Cabe esclarecer que, a partir da promulgação da Emenda Constitucional n. ${ }^{\circ} 20$, de 15 de dezembro de 1998, a aposentadoria especial fica restrita, exclusivamente, aos professores que exercem atividades docentes em sala de aula.

$\mathrm{O}$ readaptado, como se sabe, é considerado inválido às atividades docentes e, pelo fato de exercerem trabalho extra-classe, a Administração Pública, assumindo uma posição questionável, lhe retira o direito à aposentadoria especial.

Significa isso que a Administração, com base em legislação específica, obsta o direito à aposentadoria especial aos professores que adoecem, vitimados por agravos inerentes ao próprio trabalho que realizam.

Revelam os professores, ainda, que sentem medo de adoecer em serviço e ter que se aposentar por invalidez, uma vez que a queda repentina do nível sócio-econômico interferiria negativamente na qualidade de vida.

O medo também apareceu ligado ao fato de que, uma vez afastados da docência, passem a ser discriminados, encostados, o que lhes causaria ainda maior constrangimento.

“... esta pesquisa trouxe-me a oportunidade de expor o meu "ponto de vista" sobre os problemas encontrados no nosso cotidiano. A falta de reconhecimento pelas autoridades/órgãos educacionais faz-nos sentir como simples "trabalhadores" exercendo uma função meramente braçal. Se 
adoecemos, somos substituidos por outros e encostados (readaptados). Quanto aos alunos, procuramos sempre saber o que os afeta, quais os problemas que estão vivenciando, o que podemos fazer para ajudá-los. Muitas vezes somos ofendidos e maltratados por eles, mas sempre procuramos compreender os seus motivos. Mas $e$ os nossos, quem os compreende?...". (professor de ensino fundamental com jornada de quarenta horas semanais)

As situações de violência ocorridas nas escolas em que trabalham, citadas por ambos os grupos foram: indisciplina em sala de aula; roubo de material escolar; ameaças e insultos ao professor pelo aluno; violência à porta da escola e pichações. Essas situações vêm se exacerbando cada vez mais ao longo dessa última década nas escolas paulistas. Ainda que tenham sido menos freqüentes ao longo da carreira dos professores readaptados, quando passaram a ocorrer no cotidiano desses profissionais, de certa forma os pegaram despreparados para lidar com elas. De outro lado, para os professores mais jovens, em exercicio, para os quais essas realidades são mais "familiares", não deixam de constituir elementos estressantes.

\subsection{Satisfação e insatisfação no trabalho}

A maioria dos entrevistados, independentemente de estarem em exercício ou readaptados, considerou mudanças freqüentes e desvalorização profissional como fatores prejudiciais para a motivação ao trabalho. 
Parece haver no trabalho dos professores um desequilíbrio entre os motivos que os atraem a permanecer na profissão e os motivos que os impedem de atingir suas metas.

O fato de o indivíduo não atingir uma meta é frustrante, e um dos modos que utilizam para lidar com a frustração é abandonar as circunstâncias que causam esses sentimentos, ou retrair-se: o retraimento, segundo OLIVEIRA (2000), pode ser físico, como quando se foge da cena, ou pode ser internalizado, levando à letargia extrema encontrada na apatia.

Em conseqüência, novamente se defrontam com alvos desagradáveis: continuar no trabalho que lhes causa sofrimento mental, mas ao mesmo tempo é o que sempre fizeram e dizem gostar de fazer, ou abandonar a função de professor e correr o risco de ficar desempregado, ou ainda ter que se iniciar em outro trabalho que também poderá trazer os mesmos problemas.

Tomando por base o que dizem na pesquisa, os profissionais sentemse desvalorizados pela Administração Pública que não os remunera adequadamente, não organiza o serviço de modo a facilitar o cumprimento de suas funções, não valoriza o trabalho docente. Alguns acrescentam que os órgãos oficiais estão mais interessados nas ingerências políticas do que na efetiva solução dos problemas educacionais. Tal sentimento encontra-se relacionado à própria representação (ao que representa o professor) do professor na sociedade. Esse sentimento de autodesvalorização pode ser exemplificado por uma das falas:

“... a frustração do dia a dia causa um sentimento de inutilidade e baixa estima que o aniquila e o deprime. Se não for forte espiritualmente, pode 
levá-lo até à morte, pois interfere na saúde do corpo ou, então, ser frio, calculista como um mercenário o é e "levar tocando a vidinha" sem moral, sem ética, sem servir verdadeiramente como um bom cidadão que se formou e jurou para tal..." (professor de ensino fundamental, readaptado).

Dado interessante refere-se a que $63,6 \%$ dos readaptados não concordaram com a afirmação de serem responsáveis pelo fracasso dos alunos, contra $45,2 \%$ dos professores em exercício. Embora os cálculos estatísticos não tenham evidenciado diferença significativa nas respostas dos entrevistados, este tipo de sentimento parece causar maior desconforto aos professores em exercício.

No que se refere à importância da tarefa educativa, a representação que os professores têm da falta de reconhecimento e de valorização por parte das pessoas que os cercam reforça os sentimentos de indignidade e de inutilidade. Sentem um mal-estar por não conseguirem contra-argumentar as críticas de que são alvos fáceis. Sentem-se perplexos e despreparados para reverter essa situação e restabelecer o diálogo que possa lhes trazer suporte afetivo.

CODO (1999) resume os problemas, indignação e perplexidade dos professores em um só texto:

“... ora, se o professor considera que não tem nada a ver com o produto final do seu trabalho; se sente que tanto faz a forma como ele ensina, pois os alunos não estão nem ai, não querem nada com nada; se sente que tanto faz a forma como avalia, pois no final das contas, lá no Conselho de Classe, decide-se por aprovar todo mundo mesmo; se sente que o afeto que 
destina aos alunos na tentativa de conquistá-los não os atinge, nem mesmo o atendimento personalizado a cada um dos 30 ou 40 alunos das suas turmas os comove, chega um momento que cansa, esgota-se, sente-se literalmente exaurido, não agüenta mais oferecer sem receber nada em troca. Se de um lado, com todos esses percalços se sente esgotado emocionalmente, de outro, despersonaliza a relação, passa a dar aulas sempre da mesma forma, todos os alunos passam a ser iguais, fecha os olhos para os problemas do dia-a-dia e para as diferenças que antes o fascinavam. Não consegue mais ter a iniciativa de procurar colegas para discutir ou para trocar experiências. Não tem mais paciência para ouvir o pai que traz sempre a mesma desculpa, aliás, nem chama mais pai nenhum, quer mais é que se virem ...".

Estudos de MENEZES (1999) indicam que o baixo envolvimento pessoal no trabalho, também entendido como falta de realização pessoal, ocorre na relação afeto-trabalho. Interditada a relação, o trabalho perde o sentido, pois já não há mais a ilusão de que as coisas possam melhorar. Assim, não se consegue ver saída para o impasse que se estabelece entre o compromisso com o trabalho e o conflito advindo dele.

Os professores revelam, na pesquisa, que, quando atingem esse impasse, quer pela exaustão emocional, quer pelo baixo envolvimento, sentem que já não conseguem atingir os objetivos aos quais se propuseram. É que esse sentimento leva à sensação de impotência, de incapacidade pessoal para realizar aquilo que sonharam. Num processo contínuo, no qual a expectativa colocada em si próprio é muito alta, o não alcance dos objetivos passa a ter um peso insustentável. Como 
resultado, avaliam a si próprios negativamente, com respeito ao próprio trabalho com os alunos.

Como as principais causas de angústias e ansiedades, foi comum a todos os professores entrevistados mencionar as mudanças contínuas nas políticas educacionais e nas propostas pedagógicas sem preparo prévio para colocá-las em prática, o que nos remete às questões da formação e qualificação do professor já comentadas anteriormente, especialmente se considerarmos que a outra causa de ansiedades e angústias foi atribuída à falta de tempo para reciclagem e atualização de seus conhecimentos e para novas aprendizagens. Declararam que se trata de situação que lhes causa inseguranças que resultam em estresse, com todas as suas repercussões na saúde.

Em nossos resultados, também vimos que os fatores organizacionais do ambiente de trabalho e a baixa realização profissional pelo fato de não conseguir atingir os objetivos propostos, exercem influências sobre o professor que originam sentimento de impotência capaz de interferir em sua vida pessoal e agravar suas condições de saúde, questões também já discutidas.

Os fatores motivadores dos sentimentos de indignidade, inutilidade, frustração, mágoa e de insatisfação não se limitam aos já identificados neste estudo. Outros, como o salário, merecem atenção especial, principalmente quando se constata que o salário recebido por um professor, com regime de trabalho de quarenta horas semanais, é inferior ao percebido por um profissional sem a qualificação exigida para o trabalho docente. Nas questões de salário, os professores revelam-se revoltados com o tratamento discriminado que recebem. 
A insatisfação com a remuneração percebida foi praticamente unânime, à exceção de dois jovens professores em exercício.

É importante ressaltar que uma professora do ensino fundamental demonstrou satisfação com o salário, esclarecendo-se, contudo, que é solteira, não tem filhos e mora com os pais. Alegou que seu salário lhe é suficiente. Outra professora disse estar satisfeita com o salário, tendo em vista que há muito tempo estava desempregada. Em casos como esse, não se pode precisar se a satisfação advém do fato de agora estar empregada ou se da suficiência do salário para a sobrevivência.

A política salarial para o pessoal do magistério torna instável a situação funcional do docente, obrigando-o ao aumento da jornada de trabalho e à rotatividade por escolas diferentes. Com isso, não há tempo para novas aprendizagens, o que leva a frustrações quanto aos objetivos da tarefa docente.

Pesquisa de MELLO (1994) confirma que o salário dos professores não é de forma nenhuma dispensável no orçamento familiar. Para a grande maioria, constitui a única fonte de renda.

Alguns depoimentos indicam que a proletarização do professor do ensino municipal parece ser ainda mais grave do que se tem notícia. Requer imediata elaboração de uma política salarial que contemple, no mínimo, os preceitos constitucionais. Revelam que a remuneração não é suficiente para garantir uma vida digna ao professor, uma vez que sequer lhe garante a satisfação das condições minimas de que é merecedor. 
“... excesso de trabalho, sem condições de ter um convênio médico decente, subnutrido, mal alimentado, sem o menor ânimo para reciclar-me, sem condições para formação e educação contínuas..." (professor de ensino fundamental com jornada de quarenta horas semanais).

“... a remuneração de qualquer pessoa e em especial do professor, deveria ser suficiente para levar uma vida digna. Como geralmente isso não acontece, o professor precisa dar aulas em outras escolas, o que contribui para um maior desgaste, que poderá comprometer sua saúde..." (professor de ensino fundamental com jornada de quarenta horas semanais).

Parece que o sentimento de indignidade é acentuado pela baixa remuneração, uma vez que percebem, com clareza, que na política salarial do município não existe relação entre salário e desempenho, nem correlação entre salário e formação acadêmica. Ao invés, o que observam é que a remuneração é obtida pelo simples fato de participarem do quadro de professores (servidores públicos) e apresentarem um desempenho mínimo.

O assunto é enfocado em quase todos os depoimentos. Acredita-se que não poderiam pensar diferente, tendo em vista os valores irrisórios da remuneração, tornando-se ainda mais gritantes quando comparados com outras categorias de profissões que não exigem o mesmo nível de qualificação:

“... porque depois de 23 anos de prestação de serviço à escola municipal, sei que não sou remunerado adequadamente. Como profissional me sinto no direito de atender minhas necessidades familiares e não consigo, 
mas pelos anos de trabalho deveria estar conseguindo..." (professor de educação infantil, readaptado).

“... ao fim de trinta anos de trabalho temer aposentar-se e não dar conta dos encargos financeiros é preocupante. Também ainda pagar aluguel e não ver para essa classe de trabalhadores uma política efetiva para a casa própria, também é preocupante..." (professor de educação infantil com jornada de quarenta horas semanais).

Ao observar a freqüência e ênfase dada nos discursos às questões salariais, os professores do sexo masculino, talvez pelas próprias características culturais, foram os que demonstraram maior preocupação com esse fator. Parecem sentir-se mais responsáveis pela manutenção da família.

No que se refere aos componentes da saúde física e mental, $C O D A$ (1986) ressalta que alta satisfação no trabalho é importante para a saúde mental do indivíduo, na medida em que aquela poderá ter uma extensão do seu efeito para a vida particular e, ao contrário, caso ocorra a insatisfação no trabalho, esta será acompanhada de desapontamento que permeará a vida do indivíduo afetando seu comportamento também fora do trabalho. Para esse autor, satisfação no trabalho é um dos principais componentes para a satisfação geral com a vida e uma estimativa subjetiva de bem-estar.

ROCHA (1996) contribui para esta discussão ao estudar a relação trabalho-saúde de analistas de sistemas no Estado de São Paulo, e ao identificar a satisfação no trabalho como um fator protetor da saúde, aparecendo como fator de diminuição na freqüência de sintomas do "estado nervoso", distúrbios 
neurovegetativos, alterações do hábito alimentar e problemas digestivos. Neste estudo, a satisfação no trabalho também aparece associada negativamente à procura de consulta médica, e como fator de redução da interferência do trabalho na vida familiar e pessoal.

Segundo ROCHA, fatores que aparecem associados à satisfação no trabalho são o aprendizado constante, o controle sobre o processo de trabalho, o sentimento de ser um artista produzindo uma obra ao desenhar o sistema (possibilidade de criação), e a percepção de desafio na resolução de problemas. Uma limitação dos estudos epidemiológicos, no entanto, é que eles não explicam a dinâmica das correlações identificadas. Segundo ALMEIDA FILHO e ROUQUAYROL (1992), o que difere o dado epidemiológico do dado clínico é que o caráter da epidemiologia é eminentemente observacional, em que o olhar sobre a situação de saúde (ou doença) é de natureza externa, por meio da comparação entre subgrupos de uma dada amostra ou população, com diagnóstico fundamentado em abordagem indutiva e na produção de dados simplificados e padronizados. Difere do dado clínico, uma vez que este oferece conhecimento detalhado de cada caso.

Todos os professores, tanto em exercício $(100,0 \%)$ quanto readaptados $(100,0)$, concordaram com a necessidade de se respeitarem duas condições básicas, simultaneamente relacionadas, para a atuação eficiente: condições de vida saudável com todos os seus determinantes (remuneração condigna, assistência à saúde, boa alimentação, tempo e oportunidade para reciclar-se) e formação e educação contínuas, conforme preconizadas por SEVERINO (1992). 
No caso da Escola Pública, observa-se que a sociedade simplifica os males da escola, declarando os professores responsáveis universais por tudo o que nela possa haver de errado, inclusive quando se trata de problemas em que a responsabilidade real do professor e sua capacidade para evitá-los é muito limitada.

Pelo que se depreende de nossos resultados, os professores sentem-se estressados diante das pressões de uma sociedade que os responsabiliza por todos os males da escola. Declaram que essa situação lhes causa aborrecimento e lhes diminui o estímulo.

Observa-se, portanto, a elaboração de uma imagem de indignidade, advinda da simplificação do ato pedagógico, o que torna essa tarefa desinteressante, repetitiva, parcial e monótona. Para DEJOURS (1997), essa imagem de indignidade origina-se na execução forçada de uma atividade desinteressante. Esse sentimento de indignidade fica mais forte ainda quando se lhe é somada a falta de significação no trabalho do dia-a-dia.

Essa incongruência básica existente entre a organização escolar e os professores parece ampliar-lhes o sofrimento mental no trabalho. DEJOURS (1992) diz que o drama do sofrimento patogênico se localiza: na negação, colocada pela gerência, no reconhecimento de uma discordância irredutível entre organização do trabalho prescrita e organização do trabalho real.

Para melhor entender o que é sofrimento mental, pode-se partir de DEJOURS (1992) em busca de uma definição: (...) como o espaço de luta que cobre o campo situado entre, de um lado, o bem estar (...) e, de outro, a doença mental ou a loucura. O autor ainda salienta que a loucura, quando surge, faz aparecer sintomas de delírio, depressão, fobia, inibição, excitação e outras anormalidades mentais, cuja 
forma se origina mais na organização da personalidade, na história e no passado de cada pessoa, do que na situação de trabalho, mas que esta resulta como desencadeadora da doença.

Segundo GLOBE \& PORTER (1998), nas últimas décadas ocorreu substancial transferência de responsabilidades, por parte da comunidade social e da família, à escola, sem que essa transferência se fizesse acompanhar das necessárias mudanças na formação dos educadores, preparando-os para enfrentá-las com êxito, nem dos meios estruturais necessários para adaptar-se às novas circunstâncias.

Instados a manifestar-se a respeito, responderam, os professores, que o trabalho educativo fica muito dificil quando se tem que ser mãe, babá, enfermeira dos alunos, e também discordam das medidas que lhes atribuem responsabilidades extra-escolares, pois acham que, para poder desempenhá-las, as atividades especificas de ensino acabam sendo prejudicadas.

Praticamente todos os professores entrevistados concordaram com o fato de ter ocorrido substancial transferência de responsabilidades, por parte da comunidade social e da família, para a escola, sem que tal transferência de responsabilidades tenha se acompanhado das mudanças necessárias na formação dos educadores. Apenas dois professores em exercício (representando 4,7\% da amostra total) entendem que esse comportamento da sociedade não significa transferência de responsabilidades à escola.

“... me senti uma pessoa, uma profissional e não um CPF. É bom saber que existem pessoas que mesmo à distância se interessam em saber o que vive e pensa o professor. O professor tem pouco tempo disponivel, é 
verdade, mas acumula as funções de parente (aquela pessoa que se preocupa, que está sempre perto e em quem se pode confiar), de assistente social, psicóloga, enfermeira etc. O envolvimento emocional é inevitável, cada vez mais, pelo abandono e decadência das familias. Minha readaptação é por motivos de coluna, tendinite e estresse..." (professor de educação infantil, readaptado).

\footnotetext{
“... as funções docentes são altamente prejudicadas por essa transferência de responsabilidades uma vez que o educador não está preparado para atendê-las e desempenhar suas atividades a contento..." (professor de ensino fundamental readaptado).
}

\subsection{O sofrimento institucional}

Foram comuns e freqüentes os seguintes relatos quanto às situações desgastantes causadoras de sofrimento e insatisfação na atividade docente do grupo estudado: superlotação das salas de aula; baixa remuneração; falta de reconhecimento da profissão pela sociedade (incluindo a familia do aluno, a mídia e as autoridades responsáveis pelo ensino); a falta de limites dos alunos e suas atitudes responsivas inadequadas ao ambiente; e a transferência de responsabilidades extradocentes. Especificamente com relação aos professores do ensino fundamental, a grande maioria deles citou o fato de não conseguirem levar o aluno a se interessar pela aprendizagem como situação extremamente desgastante.

De alguma forma, todas estes fatores aos quais os professores atribuem a responsabilidade pelos sofrimentos e insatisfações profissionais já foram discutidos. 
Como se sabe, o trabalho é mediador de integração social, seja por seu valor econômico que propicia a subsistência, seja pelo valor simbólico, intervindo na constituição dos modos de vida e nas relações sociais. É através dele que as pessoas realizam sonhos e projetos de vida. É nele que as pessoas concentram seus esforços, capacidades e competências ao longo da vida.

Através do trabalho as pessoas esperam poder experimentar a sensação de que contribuem para a consecução de objetivos sociais e pessoais e de que se aprimoram como pessoa e como profissional.

O não reconhecimento pelo trabalho compõe-se da idéia segundo a qual o fracasso escolar é responsabilidade dos professores, seja porque faltam muito às aulas, seja porque não têm competência para ensinar, seja porque não dominam as classes, ou no que se refere à disciplina dos alunos. Tal aspecto é visto como algo que repercute na sensação de bem-estar dos educadores, na medida em que frustra o desenvolvimento de potencialidades e expectativas e que não proporciona a vivência de a pessoa ser valorizada por aquilo que faz.

Em dissertação de mestrado sobre carreiras gerenciais no serviço público, KFOURI (1992) relata que a falta de reconhecimento pelo trabalho é identificada como uma das fontes de insatisfação de gerentes de órgãos públicos, os quais advogam a necessidade de divulgar suas realizações e estabelecer contato com várias pessoas como forma de receber algum tipo de reconhecimento.

Alguns relatos enfatizam o não reconhecimento por parte da sociedade, da mídia, do público que, por um lado, se beneficia com os serviços prestados pela escola e, por outro, não demonstra reconhecimento: 
“... primeiramente um descaso da família e do governo, achando que a escola deve arcar com todos os problemas dos alunos. Acredito na instituição escola como um espaço para aprender e não como ocorre nos dias de hoje, que tudo a escola tem que resolver sozinha. Baixa remuneração, desrespeito pelo profissional, descaso do governo, salas superlotadas, alunos desinteressados, descaso da familia que acha que a escola é que tem que educar; ainda não sou readaptada ... mas do jeito que as coisas caminham sinto que não terei saúde para me aposentar na sala de aula, pois cada dia está mais dificil de se ensinar. Eu fico indignada, triste, chateada em ver a que ponto chegou a educação neste país, portanto, farei de tudo para largar a sala de aula, tirar dos meus ombros esse peso que só o professor, e mais ninguém, carrega..." (professor de ensino fundamental com tripla jornada de trabalho semanal).

“... sempre é bom sermos ouvidos, e isso me sensibiliza muito. Gostariamos mais de sermos ouvidos e atendidos nas pequenas coisas que se fazem grandes depois. A vida moderna nos leva a atualizar, ler, redigir, redimensionar, refletir, refazer e reaprender a cada momento. $O$ mais vulnerável nestes tempos modernos é o professor. Ele não tem tempo para si; sua auto-estima está baixa, convive com o estresse diário. É necessário também mudar o "olhar" para nossos educadores (compreendê-los, capacitá-los, humanizá-los e valorizá-los)". (professor de ensino fundamental com jornada de quarenta horas semanais). 
Nesse particular, a percepção do não reconhecimento apareceu como um dos aspectos mais relevantes relacionados ao sofrimento no trabalho, na análise das respostas aos questionários, segundo critérios de freqüência e intensidade.

Quando indagados sobre ao que atribuem o aumento do número de professores readaptados, novamente enfatizaram o estresse causado pelo excesso de alunos em sala de aula; a desvalorização da profissão docente; a baixa remuneração que enseja jornadas extensas de trabalho que, por sua vez, impedem horários adequados para alimentação saudável e atividades de descanso e lazer.

Os professores readaptados declararam que o que os levou à readaptação foi o estresse, o cansaço físico e mental (enquanto causas de problemas físicos precoces como hipertensão, desordens da audição e da voz, problemas vasculares). A maioria deles declarou que responder ao instrumento desta pesquisa lhes permitiu se expressar sobre as suas angústias, satisfações e insatisfações na profissão docente.

Todos os aspectos detectados neste estudo já haviam sido pontuados por MENEZES (1999), após levantamento de problemas de saúde mental e condições de trabalho docente. A autora argumenta que, muitas vezes, o professor se encontra diante de uma armadilha: de um lado, a imposição de ser um idealista, de outro, os mecanismos de preservação contra o sofrimento que impõem um arrefecimento, um freio. Para MENEZES, o resultado dessa luta entre duas condições básicas a fim de preservar a identidade é a exaustão emocional.

Segundo a mesma autora, exaustão emocional se diferencia do cansaço. Neste último, o indivíduo simplesmente pára; se não puder parar, acaba por exaurir-se. Já a primeira é o resultado de uma exposição constante, cotidiana, a uma 
contradição aparentemente sem saída. É emocional na exata medida em que a própria identidade está contida entre dois pólos igualmente decisivos. De um lado, uma vida que castra os sonhos um a um, de outro, uma profissão que tem nos sonhos o seu modo de ser. Frustrados os sonhos, tanto física quanto emocionalmente o professor acaba exausto. Os alunos passam a aborrecê-lo, seu envolvimento pessoal com o trabalho fica comprometido.

Um argumento citado pelos professores é que, cansados de doar-se sem obter um retorno do afeto empregado, deixam de investir no trabalho, acomodam-se. Acomodam-se, mas passam a sentir-se infelizes. E é como se essa infelicidade se somatizasse em seus corpos.

Enquanto pesquisadora, temos certeza de que a significância deste estudo não foi além de ratificar que anos de semeadura sem frutos concretamente visualizados, só podem resultar em insalubre desgaste físico e emocional.

Inúmeros são os aspectos da atividade docente que simbolizam agravos à saúde do professor; na essência, configuram antes todo o continuum de uma situação sociocultural, econômica e política que deve ser revista.

Prevenir a readaptação do professor de escola pública municipal, enquanto reflexo de alterações em sua saúde, implica rever e adequar, efetivamente, todo esse continuum situacional, numa perspectiva ampla, ou, como mostra objetivamente, com dados concretos, este estudo, repensar o tempo útil de atuação do professor em sala de aula mediante as condições sob as quais obrigatoriamente atua, numa perspectiva mais estrita. 


\section{CONCLUSÃO}

Uma das hipóteses aventadas no presente estudo é a de que o professor perde a capacidade funcional, pelo fato de não se sentir suficientemente preparado para enfrentar os desafios do trabalho docente, na forma como eles hoje se apresentam, uma vez que novos desafios, contradições e conflitos emergem das políticas de ajuste aos processos de globalização.

Corroborando a hipótese, parece que os professores não sabem ao certo qual o papel da escola, nem o que e como ensinar, diante de uma realidade na qual a reestruturação produtiva exige transformações radicais no campo da educação, o que pode causar-lhes agravos à saúde.

Em relação a essa premissa, a conclusão mais importante foi a de que a qualificação profissional apareceu significativamente associada à capacidade laborativa, em que níveis de escolaridade superior do professor estavam relacionados a melhores condições de saúde e capacidade para o trabalho entre os educadores da população estudada.

Essas associações ocorreram independentemente de outras variáveis, demonstrando a relevância de uma formação sólida para o desempenho das atividades docentes, considerando que os professores readaptados - que perderam a capacidade funcional por questões de saúde - aparecem, na amostra, como detentores de formação profissional significativamente inferior à dos professores em exercício. 
Naturalmente, não nos referimos à formação de início de carreira e sim à formação necessária à regência de classes, àquela construída no dia-a-dia, em conformidade com os contextos institucional e da escola.

A valiosa contribuição dos readaptados, nesta pesquisa, foi a de permitir captar um lado geralmente não perceptível em equações e médias estatísticas: o lado real do trabalho docente. $O$ lado da tarefa educativa que não pode ser obtido pela execução estrita da organização prescrita. O lado que, na prática, é ajustado, rearranjado, imaginado, inventado pelo professor.

Embora estes resultados possam servir mais aos professores em exercício e menos aos readaptados, estes atuaram como uma espécie de grupo controle, possibilitando a oportunidade de se concluir que o professor tem a saúde expropriada (pelo desencadeamento de insegurança e estresse), quando é desqualificado do saber/fazer docente, quando perde o domínio da prática necessária à tarefa educativa. Possibilitaram concluir, ainda, que a cada inovação pedagógica ou mudança paradigmática praticada à margem do magistério, desprofissionaliza-se o educador. Subtraem os objetivos, os meios, as práticas do trabalho educativo.

A organização e condições de trabalho da população estudada são aqui caracterizadas pela realização de trabalho intelectual, com uso de habilidades mentais, recepção, elaboração e transmissão de informações, podendo configurar aumento de carga mental, com possibilidade de ocorrência de fadiga mental.

Ao mesmo tempo, os fenômenos saúde-doença, estudados conforme o contexto econômico, político e organizacional do trabalho educativo, e não apenas 
como fenômeno biológico de âmbito individual, atentam para ponderações conclusivas.

No estudo das condições e da organização do trabalho educativo, conforme caracterização e contexto referidos, a conclusão de relevo foi a de que o tempo de serviço no magistério apareceu significativamente associado às condições de saúde, em que o maior tempo de permanência no trabalho docente estava estatisticamente relacionado a piores condições de saúde e incapacidade para o trabalho - na variável idade, os professores readaptados, aleatoriamente selecionados para a amostra, encontram-se, todos, em faixa etária superior à dos professores em exercício, o que significa maior tempo de serviço no magistério. Então, o que os resultados de fato evidenciam é que professores que trabalham expostos e sob o efeito de estressores, em conformidade com os diagnosticados na pesquisa, não conseguem permanecer em atividade de sala de aula por muito tempo. Muitos deles perdem a capacidade laborativa por problemas de saúde, precocemente. Não fosse desse modo, encerrariam a carreira, por vezes, cansados, mas em condições de higidez.

Reiterando pressupostos segundo os quais a percepção a respeito das relações entre as trocas sociais influencia o comportamento, é possível que se considerem os professores como sendo trabalhadores inseridos em uma sociedade capitalista que, como os demais, vendem sua força de trabalho e que o preço desse trabalho deve ser equivalente ao da manutenção dessa mesma força. Isso pressupõe sobrevivência própria e da família, transporte adequado para chegar ao trabalho, 
compra de livros, vídeos, computadores, cursos para manter atualizado o seu conhecimento.

Essa constatação nos leva a concluir, ainda que por meio de percepções do grupo de estudo, que a remuneração percebida pelos professores é arbitrária, ou seja, não existe relação entre o esforço do professor e o pagamento que recebe por esse esforço; que não existe coerência entre a remuneração e os requisitos exigidos para a realização do trabalho docente; que a remuneração não cobre, ao menos, os gastos necessários à manutenção da força de trabalho despendida por um professor; que essa situação é por ele percebida como de iniqüidade, e que a iniqüidade causa sofrimento, influencia a motivação e pode conduzir a ressentimentos. Nesse particular, já se percebe uma situação aflitiva e estressante condicionando a qualidade do trabalho - os baixos salários, entre outros, são apontados como fatores fundamentais para o estabelecimento de situações de malestar.

Os aspectos psicossociais do trabalho que apareceram como sendo mais insatisfatórios foram: falta de tempo para cumprir tudo aquilo que o professor considera seu dever; dificuldades ante o baixo desempenho dos alunos e classes excessivamente numerosas; falta de apoio e reconhecimento do trabalho docente; acúmulo de responsabilidades sem a contrapartida para poder cumpri-las; jornadas extenuantes. 
A análise ergonômica do trabalho demonstrou ser uma técnica adequada para identificação das características, das condições e da organização do trabalho que possam estar causando agravos à saúde do professor.

Devido à sua complexidade, à multiplicidade de teorias existentes e ao seu caráter subjetivo, é necessário rigor metodológico na escolha do referencial teórico e das estratégias de pesquisa, incluindo instrumentos e técnicas para coleta e análise dos dados. Também são necessários cuidados quanto à abordagem, comunicação e entrada no campo de pesquisa para obtenção da aceitação e adesão dos participantes do estudo. Neste sentido, as estratégias, métodos e instrumentos utilizados nesta pesquisa mostraram ser adequados aos objetivos propostos.

Uma limitação deste estudo é que, por tratar-se de estudo com desenho transversal, não foi possível estabelecer relações causais entre satisfação e saúde. Para isso são necessários estudos longitudinais controlados.

Os resultados mostram que o professor não se sente recompensado, porquanto não contempla os frutos de seu trabalho. Se o objetivo é ensinar, causa-lhe sofrimento perceber que não consegue fazê-lo. Afinal, como poderia, se não está devidamente preparado para desempenhar sua função, face à velocidade das mudanças de políticas educacionais e de linhas pedagógicas que lhes são impostas, uma vez que estas, não raro, desconhecem a dimensão real da profissão docente.

Por outro lado, os professores não conseguem responder às solicitações do contexto, pelo excesso de responsabilidades assistenciais e sociais transferidas à escola, em detrimento do trabalho pedagógico e por não disporem de 
tempo e condições de melhorar sua formação. Dever-se-ia dizer que a cada dia constatam sua incapacidade e perdem a segurança em si mesmos.

O nível de estresse assim gerado decisivamente influirá no estado de saúde. Dessa forma, tomando-se os professores readaptados como representantes dos que tiveram a saúde agravada por problemas relacionados às condições de trabalho, sentimo-nos à vontade para especular se os professores em exercício, mais jovens e mais suscetíveis a essas condições de trabalho, não seriam alcançados por esse processo estressante, ainda mais precocemente que os professores readaptados da amostra.

Por todo o exposto é que, ao concluirmos este estudo, sugerimos condutas preventivas ao agravo da saúde dos professores. 


\section{CONSIDERAÇÕES FINAIS}

O trabalho é um modo pelo qual o homem se realiza e dá sentido à sua existência, na qual a realização de uma atividade satisfatória, que venha ao encontro de seus valores e que proporcione prazer, aparece associada a uma melhor capacidade para o trabalho e a melhores condições de saúde, tanto física como mental.

Os agravos à saúde relacionados ao trabalho, de diagnóstico e estabelecimento de nexo causal complexos e nem sempre claros, necessitam, muitas vezes, de tratamentos que exigem a adoção de medidas corretivas que interferem não só nos aspectos ambientais, mas também nas relações e na organização do trabalho.

Assim, a título de prevenção à saúde dos professores e à sua capacidade laboral sugere-se refletir e avaliar mudanças na concepção e organização do trabalho, direcionadas para os aspectos psicossociais da atividade docente.

Estas sugestões preventivas compreendem:

- Discussão anterior, conceituação e consolidação de idéias para direcionar as mudanças aos interesses e necessidades dos professores;

- Definição de diretrizes e linhas pedagógicas mais constantes a serem implementadas nas escolas públicas do município de São Paulo, que passem além das administrações ou de mudanças de chefias;

- Mudanças nas formas de reconhecimento e valorização dos professores e de seu trabalho, tendo em vista que o reconhecimento é a forma de retribuição moral/simbólica dada ao ego como compensação pelo engajamento e pela 
eficácia do trabalho (DEJOURS, 1997). Por exemplo, a qualificação de chefias para o desenvolvimento de habilidades no sentido de reconhecer tanto as exigências do trabalho real como o interesse e os esforços empreendidos pelos professores, ou a qualidade do trabalho realizado; dar conhecimento aos professores deste reconhecimento, seja por meio de comunicação formal ou informal, levando em consideração as formas mais aceitas ou valorizadas pela equipe de professores; redimensionar as formas de avaliação de desempenho legalmente instituídas no sistema de ensino do município de São Paulo, porquanto não mais produzem o efeito desejado, na forma como são utilizadas; definir incentivos ou formas de reconhecer esforços desenvolvidos e trabalhos realizados com dedicação, bem como ter claros os critérios de concessão dos mesmos, para que não se transformem em formalidades desprovidas de objetividade;

- Mudanças nos processos de formação continuada que implementem a melhoria do trabalho docente, priorizando aumento do nivel de habilidades dos professores, a partir do envolvimento de todos no processo de formação, desde a sua concepção até a avaliação dos resultados e desde que sejam por eles percebidas como aspectos positivos e complementares à atividade docente, uma vez que não há como os educadores apreenderem toda a gama de informações e conhecimentos, face à velocidade com que, hoje, são produzidos. Por exemplo, possibilitar o desenvolvimento de uma metodologia de grupo de auto-aprendizagem que ofereça ao professor a possibilidade de compartilhar, em nível relacional e humano, as respostas que estão dando outros educadores aos mesmos problemas; desenvolvimento de atividades interessantes e mais complexas, que utilizem os conhecimentos e habilidades que os professores já dispõem ou o aprendizado e desenvolvimento de 
novas habilidades que signifiquem desafios que venham ao encontro das expectativas dos professores e que consolidem uma estrutura básica de sustentação, capaz de leválos a pesquisar, buscar e selecionar informações, apreender os conhecimentos que julgarem necessários ao desenvolvimento do trabalho docente; disponibilizar uma rede de comunicação que não deve reduzir-se ao âmbito dos conteúdos acadêmicos e que inclua problemas metodológicos, organizacionais, políticos, sociais que seguidamente se unem às situações de ensino. Um dos parâmetros dessas mudanças deve ser o de evitar ambigüidades e conflitos de idéias, o excesso de trabalho ou pressões.

- Mudanças que implementem a autonomia no trabalho exercido pelos professores, com aumento da participação individual e coletiva em processos decisórios. Por exemplo, desenvolvimento de melhorias contínuas no fluxo de informações e seus suportes, de modo que possam servir como subsídios para tomada de decisões claras e objetivas; valorização da discussão e consenso de decisões entre chefias e equipe docente, bem como promoção do envolvimento dos professores nas atividades de planejamento e organização do trabalho e não só na sua execução. Essas mudanças devem ser acompanhadas de clara definição de papéis e responsabilidades, evitando os conflitos de competência e os equívocos conseqüentes ao exercício de uma autonomia irrestrita.

- Mudanças que aumentem os níveis de suporte social. Por exemplo, habilitação de chefias e profissionais de Recursos Humanos, Serviço Social e Saúde para oferecer suporte, orientações e encaminhamentos aos professores, em questões pessoais, profissionais e de saúde e para resolução de conflitos (mormente quando iniciado o processo que resultará em readaptação); 
- Mudanças que implementem um nível de demandas no trabalho, adequado às características psico-fisiológicas humanas. Por exemplo: mudanças que limitem ou impeçam um professor de ensino básico de assumir jornada tripla de trabalho docente que, no caso do município de São Paulo, chega a atingir setenta e seis horas-aula semanais; mudanças que promovam a rotatividade de professores pelos diferentes níveis de ensino (até onde permitir a qualificação profissional de cada um), a fim de que um professor de educação infantil, por exemplo, não passe até um quarto de século de sua vida trabalhando e dialogando, sempre, com interlocutores de uma mesma faixa etária, pelo menos duas décadas mais novo, numa atividade repetitiva capaz de provocar lesões em áreas nobres do sistema psíquico; prover formas de substituição de professores que se ausentam das aulas por motivos de faltas, licenças, reuniões e demais compromissos, a fim de que o professor presente à escola não seja levado a assumir até duas classes - setenta ou oitenta alunos - no mesmo dia e período;

- Mudanças nas condições do ambiente físico de trabalho. Por exemplo, adequação das condições do ambiente físico (ruído excessivo, aglomerações, trânsito de alunos pelas dependências da escola) às características psico-fisiológicas humanas de professores e alunos, orientando-se, por exemplo, pelas normas técnicas e legislação avançada em cada tema, promovendo a redução do barulho produzido pelas escolas e do excesso de movimentação - escolas que funcionam das sete às vinte e três horas, em quatro turnos diários, com interrupções a cada quarenta e cinco minutos e com número de matriculas próximo a dois mil alunos, devem refletir sobre o estabelecimento de normas técnicas de conduta e uso 
do prédio; facilitar o envolvimento dos professores na priorização, definição e desenvolvimento dessas mudanças.

Para além dos agravos à saúde, certamente, a situação do magistério, tal qual hoje se apresenta, poderá levar ao colapso do sistema de ensino, caso não se levem a efeito mudanças estruturais para evitar as insatisfações e o desgaste laboral, apontados pelos professores neste estudo. Desde a valorização, passando pelo preparo necessário ao exercício da docência e mudanças significativas e conseqüentes na organização e condições do trabalho poderão levar a uma nova imagem da função docente, tanto para o ponto de vista da sociedade, como do próprio professor, e a uma redução dos problemas hoje enfrentados por esses profissionais, que devem pôr em alerta as autoridades do ensino, as entidades de classe e a própria categoria de profissionais do magistério da rede de ensino público do município de São Paulo.

Adequar as condições de trabalho às novas exigências do ensino $\mathrm{e}$ revalorizar a imagem social da profissão docente são, hoje, medidas urgentes com as quais os professores e a administração do ensino já devem estar preocupados. Neste percurso, é preciso que os professores recuperem o orgulho de serem docentes e que a sociedade reconheça o importante trabalho que realizam. 


\section{REFERÊNCIAS}

Adorno T, Horkheimer M. Dialética do esclarecimento. Rio de Janeiro: Jorge Zahar; 1991.

Adorno TW. Educação e emancipação. Rio de Janeiro: Paz e Terra; 1995.

Almeida Filho N, Rouquayrol Z. Introdução à epidemiologia moderna. $2^{a}$ ed. Belo Horizonte: COOPMED; 1992. Metodologia da pesquisa epidemiológica; p. 79-101.

Alonso M. Custos no serviço público. Rev Serv Público 1999; 50(1): 37-62.

Arroyo MG. Ofício de mestres: imagens e auto-imagens. Petrópolis: Vozes; 2000.

Ballone GJ. Percepção e realidade. Disponível em:

<URL: http://www.psiquweb.med.br/cursos/percep.html> [2001, nov.2].

Bordieu P. Compreender. In: Bourdieu P, coordenador. A miséria do mundo. $3^{\mathrm{a}}$ ed. Petrópolis: Vozes; 1999.

Brasil. Constituição da República Federativa do Brasil. Emenda Constitucional n. ${ }^{\circ}$ 20, de 15 de dezembro de 1998. Modifica o sistema de previdência social, estabelece normas de transição e dá outras providências. Diário Oficial da Nação, Brasília [DF], 16 de dezembro de 1998.

Brasil. Ministério da Educação. Lei Federal n. ${ }^{\circ}$ 9394, de 20 de dezembro de 1996 LDB. Estabelece as Diretrizes e Bases da Educação Nacional (alterada pela Lei 9.475/1997 e Lei n. ${ }^{\circ} 10.287 / 2001$, Lei . $^{\circ} 10.328 / 2001$, Lei n. ${ }^{\circ} 10.709 / 2003$. Coletânea de Legislação Básica. publ Sindicato dos Profissionais em Educação no Ensino Municipal de São Paulo. São Paulo, novembro de 2003. p. 36-49. 
Brasil. Ministério da Educação. Conselho Nacional de Educação. Parecer n. ${ }^{\circ}$ CNE/CP 009/2001. Aprovado em 08 de maio de 2001. Homologado em 17 de janeiro de 2002. Dispõe sobre análise da proposta de Diretrizes Curriculares Nacionais para a Formação de Professores da Educação Básica, em nível superior, curso de licenciatura, de graduação plena. Rev do Conselho Municipal de Educação de São Paulo. Complementação, 2002; (1): 93-124.

Candau V, organizador. Novos rumos da licenciatura. Brasília [DF]: MEC; 1987.

Carneiro MCBGC. Um estudo de morbidade entre professores no Município de Rio Claro. São Paulo. Rio Claro: 1997. [Monografia de conclusão de curso de Pedagogia - UNESP].

Coda R. Satisfação no trabalho e características das políticas de recursos humanos para executivos. São Paulo; 1986 [Tese de Doutorado - Faculdade de Economia e Administração da USP].

Codo W., coordenador. Educação: carinho e trabalho. Petrópolis: Vozes; 1999.

Cury CRJ. Relação do saber e relação social: um ensaio. Rev Ande 1984; (8): 8-19.

Dejours C. A loucura do trabalho: estudo da psicopatologia do trabalho. $5^{\mathrm{a}} \mathrm{ed}$. ampl. São Paulo: Cortez /Oboré; 1992.

Dejours C. O fator humano. Rio de Janeiro: Fundação Getúlio Vargas; 1997.

Dejours C. Por um trabalho, fator de equilíbrio. Rev Adm Aempresas 1993; 33(3): 98-104.

Del Priori M. História das mulheres no Brasil. $3^{\text {a }}$ ed. São Paulo: Contexto; 2000.

Enguita MF. A ambigüidade da docência: entre o profissionalismo e a proletarização. Porto Alegre: Teoria Educação; 1991.

Esteve JM. O mal-estar docente: a sala de aula e a saúde dos professores. Bauru: EDUSC; 1999. 
Ferreira R. Entre o sagrado e o profano: o lugar social do professor. Rio de Janeiro: Quartet Editora \& Comunicações; 1998.

Fraser TM. Humam stress work and job satisfaction: a critical approach. Geneva: International Labour Office; 1996.

Frigotto G. organizador. A cidadania negada: políticas de exclusão na educação e no trabalho. São Paulo: Cortez; 2001.

Fusari JC, Rios T. Formação continuada dos profissionais do ensino. Cad Cedes, 1995; (36): 37-45.

Gadotti M. Organização do trabalho na escola: alguns pressupostos. São Paulo: Ática; 1993.

Globe NM, Porter JF. La cambiante función del profesor. Madrid: Narcea; 1998.

Heller A, Feher F. A condição política pós-moderna. Rio de Janeiro: Civilização Brasileira; 1998.

Kfouri BMB. Carreiras gerenciais no serviço público: caminhos num espaço sem caminhos. São Paulo; 1992. [Dissertação de mestrado - Escola de Administração de Empresas da Fundação Getúlio Vargas].

Lage N. Ideologia e técnica da notícia. Rio de Janeiro: Ática;1982.

Laurell AC, Noriega M. Processo de produção e saúde - trabalho e desgaste operário. São Paulo: Hucitec; 1989.

Mello GN. Cidadania e competitividade: desafios educacionais do terceiro milênio. São Paulo: Cortez; 1994.

Menezes IV. A si mesmo como trabalho. In: Codo W, coordenador. Educação: carinho e trabalho. Petrópolis: Vozes, 1999. 
Minayo MC. O desafio do conhecimento: pesquisa qualitativa em saúde. São Paulo: Hucitec/Rio de Janeiro:Abrasco; 1999.

Minayo GCT, Costa SMF. A construção do campo da saúde do trabalhador: percurso e dilemas. Cad Saúde Pública 1997; 13 (supl. 2): 21-32.

Moreno CRC. Critérios cronológicos na adaptação trabalho em turnos alternantes: validação de um instrumento de medida. São Paulo; 1993. [Tese de Mestrado - Faculdade de Saúde Pública da USP].

Morin E. O paradigma perdido: a natureza humana. Sintra: Publicações EuropaAmérica; 2001.

Moscovici S. Representação social da psicanálise. Rio de Janeiro: Zahar; 1998.

Murray EJ. Motivação e emoção. Rio de Janeiro: Guanabara; 1986.

Neves MACM. A crise dos paradigmas em educação na óptica da psicologia. In: Brandão, Zaia organizador. A crise dos paradigmas e a educação. $8^{\mathrm{a}}$ ed. São Paulo: Cortez; 2002.

Novaes ME. Professora primária: mestra ou tia? São Paulo: Cortez; 1987.

Nóvoa A. Relação escola-sociedade: novas respostas para um velho problema. In: Serbino, et al; organizadores. Formação de professores: São Paulo: Ed. UNESP; 1996. p. 17-36.

Nóvoa A. et. al. Vidas de profesores. $2^{\text {a }}$ ed. Porto: Editora Porto; 1992.

Oliveira DC. Práticas sociais em saúde: uma releitura à luz da teoria das representações sociais. In: Moreira ASP, Oliveira DC organizadores - Estudos interdisciplinares de Representação Social. Goiânia: AB Editora; 2000.

Paraguay AIBB. Ergonomia - trabalho. fadiga mental. Rev Brás Saúde Ocup 1997; 15 (59): 39-43. 
Paraguay AIBB, Tavares DS. Sondagem preliminar sobre a percepção da relação saúde e trabalho no Tribunal Federal da $3^{\mathrm{a}}$ Região. São Paulo; 2000. [Projeto de Pesquisa CGIO Concepção, gestão e inovação organizacional].

Penteado RZ. A voz do professor: relações entre trabalho, saúde e qualidade de vida. Rev Bras Saúde Ocup 1999; (95/96): 50-62.

Pereira B. A voz do professor: relações entre trabalho, saúde e qualidade de vida. Rev Bras de Saúde Ocup 1999; (95/96): 15-26.

Plastino CA. A crise dos paradigmas e a crise do conceito de paradigma. In: Brandão $\mathrm{Z}$, Bonamino. AC A crise dos paradigmas e a educação. $8^{\mathrm{a}}$ ed. São Paulo: Cortez; 2002.

Pochmann M. Pobreza e violência no Município de São Paulo. [on line]. Disponivel em URL: http//:www.social.org.Br/relatorio2002/relatórios/19.html [2004 nov 21].

Polaino A. El estrés de los profesores: estrategias psicológicas de intervención para su manejo y control. Rev Españ Pedag, 1982; 40 (157): 35-48.

Ribeiro H. A condição e a solidariedade cristã. Petrópolis: Vozes; 1998.

Rigotto RM. Saúde dos trabalhadores e meio ambiente em tempos de globalização e reestruturação produtiva. Rev Bras Saúde Ocup, 1998; 25 (93/94): 9-20.

Rocha LE. Estresse ocupacional em profissionais de processamento de dados: condições de trabalho e repercussões na vida e saúde dos analistas de sistemas. São Paulo; 1996. [Tese de Doutorado - Faculdade de Medicina da USP].

Rocha LE et al, organizadores. Isto é trabalho de gente? vida, doença e trabalho no Brasil. São Paulo: Vozes; 1993.

Santos BS. Pela mão de Alice: o social e o político na pós-modernidade. São Paulo: Cortez; 1996. 
São Paulo (Município de São Paulo). Lei n. ${ }^{\circ} 11.434$, de 12 de novembro de 1993. Dispõe sobre a organização dos Quadros dos Profissionais de Educação da Prefeitura do Município de São Paulo, reenquadra cargos e funções, estabelecidos na Lei 10.430 , de 29 de fevereiro de 1988 e na Lei 11.229 , de 26 de junho de 1992. Cria novas Escalas de Padrões de vencimentos e institui planos de carreiras. Coletânea de Legislação Básica: publ Sindicato dos Profissionais em Educação no Ensino Municipal de São Paulo. São Paulo, novembro de 2003. p.154-196.

São Paulo (Município de São Paulo). Lei n. ${ }^{\circ} 13.399$, de $1^{\circ}$ de agosto de 2002. Dispõe sobre a criação de Subprefeituras no Município de São Paulo, e dá outras providências. Coletânea de Textos Legais - Complementação. Prefeitura do Municipio de São Paulo. Secretaria Municipal de Educação. São Paulo, agosto de 2003. p. 31-35.

Sato L. A representação social do trabalho penoso. In. Spink MJ organizador. O conhecimento do cotidiano: as representações sociais na perspectiva da psicologia social. São Paulo: Brasiliense; 1993.

Sawaia BB. Análise psicossocial do processo saúde-doença. Rev Esc Enferm USP 1994; 28 (1) 96-104; 1994 (c).

Severino AJ. Metodologia do trabalho científico. $18^{\mathrm{a}}$ ed. São Paulo: Cortez \& Autores Associados; 1992.

Silva RN da, Davis C. É proibido repetir. Estud Aval Educ 1993; (7): 5-44.

Teixeira IM. A voz do professor: relações entre trabalho, saúde e qualidade de vida. Rev Bras Saúde Ocup 1999; (95/96): 19-28.

Teves N. O imaginário na configuração da realidade social. In Teves $\mathrm{N}$, organizador. Imaginário e educação. Rio de Janeiro: GAXPHUS; 1999. 
ANEXOS 
Anexo 1

Política de desenvolvimento do Departamento

de Saúde do Trabalhador 


\section{ANEXO 1 \\ Política de desenvolvimento do Departamento \\ de Saúde do Trabalhador}

As principais metas desse novo Departamento são:

1 - Humanizar o atendimento pericial, aumentando a eficiência e a qualidade dos serviços prestados.

2 - Consolidar a área de promoção à saúde.

Pressupostos:

- Articulação entre as atividades periciais, de vigilância e de assistência.

- Participação dos trabalhadores nos processos de vigilância/estímulo às Organizações por Local de Trabalho.

- Descentralização das atividades

O DESAT deve acompanhar a descentralização da Prefeitura, estabelecendo postos de atendimento, por macro regiões, mais próximos aos locais de moradia e trabalho dos servidores.

As ações em saúde do trabalhador envolvem diversas áreas do conhecimento como: medicina, engenharia, enfermagem, psicologia, fonoaudiologia, serviço social, terapia ocupacional, fisioterapia, odontologia, segurança do trabalho, direito, entre outras. 
Anexo 2

Agrupamento das principais restrições constantes dos

Laudos Médicos referentes aos servidores readaptados 


\section{ANEXO 2 \\ Agrupamento das principais restrições constantes dos \\ Laudos Médicos referentes aos servidores readaptados}

A. não deverá exercer atividades que exijam o uso contínuo e obrigatório da voz;

B. não deverá exercer atividades que exijam deambulação constante: subir e descer escadas com freqüência e permanência em pé por tempo prolongado; exijam o uso de força, habilidade ou movimentos repetitivos com o membro superior (esquerdo/direito).

C. não deverá exercer atividades intra ou extra-classe devendo permanecer, sob supervisão direta, em período diurno e ambiente não gerador de tensão emocional. Poderá apenas exercer atividades sem risco para si ou terceiros, em ambiente interno, calmo e não sujeitos a tensão emocional;

D. não deverá exercer atividades que exijam esforços e devem ser exercidas em ambiente calmo;

E. poderá apenas exercer atividades que não exijam contato com pó ou produto químico em geral;

Poderá apenas exercer atividades que não exijam contato com irritantes, como pós, poeira, ou mofo, em ambiente ventilado. 
Anexo 3

Termo de consentimento 


\section{ANEXO 3 \\ TERMO DE CONSENTIMENTO}

Este termo refere-se ao consentimento individual do entrevistado para que sua fala seja gravada, transcrita e analisada, com finalidade exclusiva de pesquisa.

Sobre a pesquisa:

Esta pesquisa intitulada "Quando os dados oficiais revelam condições de trabalho: análise dos agravos à saúde de professores das escolas públicas do Município de São Paulo" visa analisar as percepções dos profissionais da área da educação sobre as próprias condições de trabalho e detectar fatores que podem causar agravos à saúde desses profissionais.

Parte-se do pressuposto de que o conhecimento de situações vivenciadas no cotidiano de trabalho poderá trazer elementos para a compreensão da relação saúde-trabalho. Assim, os aspectos relevantes do trabalho em relação à saúde serão identificados a partir de dados coletados em entrevistas e observação dos ambientes de trabalho, salientando-se que o foco será o trabalho e sua forma real de organização e realização. Estas atividades serão desenvolvidas no período de setembro de 2002 a dezembro de 2004.

A todas as pessoas do local de trabalho observado será assegurado:

- o direito de informação sobre os objetivos e resultados do estudo;

queira;

- o acesso ao material de anotações da pesquisadora, caso o entrevistado o

- a apresentação e divulgação dos dados, sem divulgação de nomes.

Responsável:

Neide Sant'Anna Moura dos Santos

(Telefone: 3021-2223)

Orientadora:

Prof ${ }^{a}$. Dra. Maria da Penha C. Vasconcellos

(Telefone: 3066-7703)

Assinatura da pesquisadora

Neide Sant'Anna Moura dos Santos

$\mathrm{Eu}$,

RG número declaro consentir que a pesquisadora realize entrevista, com fins de pesquisa, mediante explicação dos objetivos e condições acima citados.

São Paulo, de de 2004

Assinatura do entrevistado 
Anexo 4

Termo de consentimento para observação no local de trabalho 


\section{ANEXO 4 \\ TERMO DE CONSENTIMENTO PARA OBSERVAÇÃO \\ NO LOCAL DE TRABALHO}

Este termo refere-se ao consentimento do Diretor de Escola para que se realize observação no local de trabalho a fim de compreender a organização do trabalho e a adequação das atividades realizadas pelos professores readaptados, com finalidade exclusiva de pesquisa.

Sobre a pesquisa:

Esta pesquisa intitulada "Quando os dados oficiais revelam condições de trabalho: análise dos agravos à saúde de professores das escolas públicas do Município de São Paulo" visa analisar as percepções dos profissionais da área da educação sobre as próprias condições de trabalho e detectar fatores que podem causar agravos à saúde desses profissionais.

Parte-se do pressuposto de que o conhecimento de situações vivenciadas no cotidiano de trabalho poderá trazer elementos para a compreensão da relação saúde-trabalho. Assim, os aspectos relevantes do trabalho em relação à saúde serão identificados a partir de dados coletados em entrevistas e observação dos ambientes de trabalho, salientando-se que o foco será o trabalho e sua forma real de organização e realização. Estas atividades serão desenvolvidas no período de setembro de 2002 a dezembro de 2004.

A todas as pessoas do local de trabalho observado será assegurado:

- o direito de informação sobre os objetivos e resultados do estudo;

queira;

- o acesso ao material de anotações da pesquisadora, caso o entrevistado o

- a apresentação e divulgação dos dados, sem divulgação de nomes.

Responsável:

Neide Sant'Anna Moura dos Santos

(Telefone: 30212223)

Orientadora:

Prof ${ }^{a}$. Dra. Maria da Penha C. Vasconcellos

(Telefone: 3066-7703)

Assinatura da pesquisadora

Neide Sant'Anna Moura dos Santos

$\mathrm{Eu}$, , RG número , declaro consentir que a pesquisadora realize observação no local de trabalho, com fins de pesquisa, mediante explicação dos objetivos e condições acima citados. 
Anexo 5

Questionário 


\section{ANEXO 5 \\ QUESTIONÁRIO}

Prezado(a) Professor(a)

Esta pesquisa intitulada: "Quando os dados oficiais revelam condições de trabalho: análise dos agravos à saúde de professores das escolas públicas do Município de São Paulo" visa analisar as percepções dos professores sobre as próprias condições de trabalho e detectar fatores que podem causar agravos à saúde desses profissionais.

Parte-se do pressuposto de que o conhecimento de situações vivenciadas no cotidiano docente poderá trazer elementos para a compreensão da relação saúde-trabalho.

A finalidade deste questionário é colher informações sobre o seu trabalho docente.

Seja sincero nas respostas: isso é importante.

Responda as questões assinalando o item correspondente à sua resposta, complementando, quando for o caso.

Agradecemos a colaboração lembrando que você estará contribuindo para a melhoria das condições de trabalho e saúde dos professores.

\section{DADOS PESSOAIS:}

Data:

Nome: (opcional)

Nome da escola:

Data de nascimento:

Sexo:

masculino
feminino

Estado civil:

Escolaridade:

Médio completo

Superior incompleto

( )

Superior completo

( )

Superior em curso

( )

Outro

( )

( )

\section{DADOS REFERENTES AO TRABALHO:}

1. A escola em que você trabalha no momento é:

Educação Infantil

Ensino Fundamental

Ensino Médio 
2. Qual a sua situação funcional na escola, hoje?

Professor efetivo com classe

( )

Professor substituto com classe

( )

Professor readaptado temporariamente

( )

Professor readaptado definitivamente

( )

Coordenador pedagógico

( )

Assistente de diretoria

( )

Diretor

( )

Outros (especificar)

( )

3. Se for readaptado, que atividades você desempenha atualmente na escola?

Faz trabalho administrativo

Cuida do recreio/entrada

( )

Atende público

É responsável pelo planejamento pedagógico

É responsável pela biblioteca

É responsável pela sala de informática

( )

( )

É responsável pela parte financeira

( )

Licença médica

( )

Outros (especificar)

( )

( )

Atenção: os professores readaptados respondem referindo-se à época em que estavam em sala de aula.

4. Qual a faixa etária dos alunos na escola em que leciona (ou quando lecionava)?
Até 6 anos
( )
De 7 a 12 anos
( )
De 13 a 18 anos
( )
Mais de 18 anos
( )

5. Quantos alunos você tem (ou tinha) por classe, em média?
Menos de 20
( )
De 21 a 30
( )
De 31 a 40
( )
De 41 a 50
( )
Mais de 50
( )

6. Qual é (ou era) a jornada semanal de trabalho?

Menos de 10 horas

De 10 a 20 horas

( )

De 20 a 30 horas

( )

De 30 a 40 horas

( )

Mais de 40 horas

( ) 
7. Você tem (ou tinha) autonomia quanto ao planejamento de suas aulas?

Sim

Não
( )

( )

8. O ambiente de trabalho :
Calmo
( )
Moderado
( )
Estressante
( )

9. Existe local adequado para descanso dos professores na escola?

Sim

Não

( )

( )

10. Você acha que o número excessivo de alunos por classe constitui fator de desgaste?

Sim

Não

( )

( )

11. Você considera o seu trabalho repetitivo?

Sim

Não

( )

( )

12. Você considera o seu trabalho cansativo?

Sim

()

Não

( )

13. Nas situações de violência, assinale as que já ocorreram na sua escola:

Depredações

( )

Roubo de material de escola

( )

Intervenção da polícia por causa de roubos

( )

Indisciplina em sala de aula

( )

Ameaça ao professor

( )

Agressões

( )

Alunos armados

( )

Tiros

( )

Insultos

( )

Violência à porta da escola

( )

Violência contra os funcionários da escola

( )

Violência sexual

Problemas de drogas

( )

Pichações 
14. A "errônea opinião pública" sobre os professores, a introdução de freqüentes mudanças, as propostas educativas redigidas à margem dos professores, as ideologias que depreciam a tarefa educativa podem levar à diminuição da motivação do trabalho do professor ?

$\operatorname{Sim}$

Não

( )

Justifique:

( )

15. A incorporação no cotidiano docente dos termos colaborador, parceiro, amplamente utilizados, oculta a cooptação dos professores segundo interesses da administração. Como colaboradores devem estar motivados e satisfeitos, decididos e atuantes, identificados com os objetivos da politica educacional e flexibilizados emocionalmente, o que significa ser maleável, complacente, submisso (Aurélio, 1998).

Como vítimas, os professores passam a ser responsáveis e culpados pelos fracassos quando estes ocorrem.

Você concorda?

Sim

( )

Não

( )

Explique sua posição:

16. A tarefa de ensinar tornou-se complicada na medida em que os educadores não podem realizar em si mesmos, de modo completo, o processo de ensino/aprendizagem, já que para ensinar é preciso estar o tempo inteiro aprendendo. No caso do professor, aprender significa refletir sobre a própria prática, sobre a vivência que leva ao confronto com inúmeros problemas cotidianos.

Diante desse quadro e da conhecida falta de tempo para reflexões, fale sobre as angústias e ansiedades do professor e se essa situação pode afetar-lhe a saúde.

Explique a sua posição: 
17. Você acha que a baixa realização no trabalho e o fato de não conseguir atingir os objetivos aos quais se propòe traz ao professor um sentimento de impotência capaz de interferir em sua saúde e bem estar?
Sim
( )
Não
( )

Explique:

18. Você acha que os fatores organizacionais do ambiente de trabalho interferem na vida pessoal e ou na saúde?

Sim

( )

Não

( )

Justifique:

19. Você acha que a remuneração pelo trabalho docente lhe é satisfatória e suficiente?
Sim
( )
Não
( )

Explique por que:

20. Você sente satisfação no desempenho de sua função?

Sim

Não

Por quê?
( )

( ) 
21. Para que o professor atue eficientemente, duas condições básicas, relacionadas ao mesmo tempo, devem ser preenchidas: primeiro, condições de vida saudável com todos os seus determinantes (remuneração condigna, assistência à saúde, boa alimentação, tempo e oportunidade para reciclar-se) e segundo, formação e educação contínuas (Severino, 1992).

Você concorda?

Sim

Não

( )

( )

Se concorda, descreva, sucintamente, o que acontece ao professor quando essas condições básicas não são preenchidas:

22. Nas últimas décadas ocorreu substancial transferência de responsabilidades, por parte da comunidade social e da familia, à escola, sem que essa transferência se fizesse acompanhar das necessárias mudanças na formação dos educadores, preparando-os para enfrentá-las com êxito, nem dos meios estruturais necessários para adaptar-se às novas circunstâncias (Globe \& Porter, 1980).

Você concorda?

Sim

( )

Não

( )

Explique como consegue desempenhar suas funções docentes quando a acumulação de responsabilidades e expectativas são desproporcionais ao tempo e aos meios de que dispõe: 
23. No caso da Escola Pública, observa-se que a sociedade simplifica os males da escola, declarando os professores responsáveis universais por tudo o que nela possa haver de errado, inclusive quando se trata de problemas em que a responsabilidade real do professor e sua capacidade para evitá-los é muito limitada.

Você concorda?

Sim ( )

Não $\quad$ ( )

Se concorda, enumere dificuldades enfrentadas na realização do trabalho:

24. Ao tradicional quadro de repetências e evasões, acrescentou-se a violência física e simbólica, a droga e o HIV-AIDS, levando o professor a uma situação de trabalho que, muitas vezes, não pode suportar, mas que ao mesmo tempo, não pode desistir.

Dê exemplos de situações identificadas como desgastantes, causadoras de sofrimento e insatisfação ao professor:

25. Como já mencionado, sua contribuição é valiosa. Fale o que quiser sobre você, sua satisfação/insatisfação no trabalho, sua saúde, qual o seu envolvimento emocional com os problemas pessoais de alunos, motivos que o (a) levaram à readaptação e como se sentiu participando desta pesquisa: 
26. Como você explica o aumento do número de professores licenciados e readaptados em razão de doenças provenientes do trabalho, no âmbito da Secretaria Municipal de Educação?

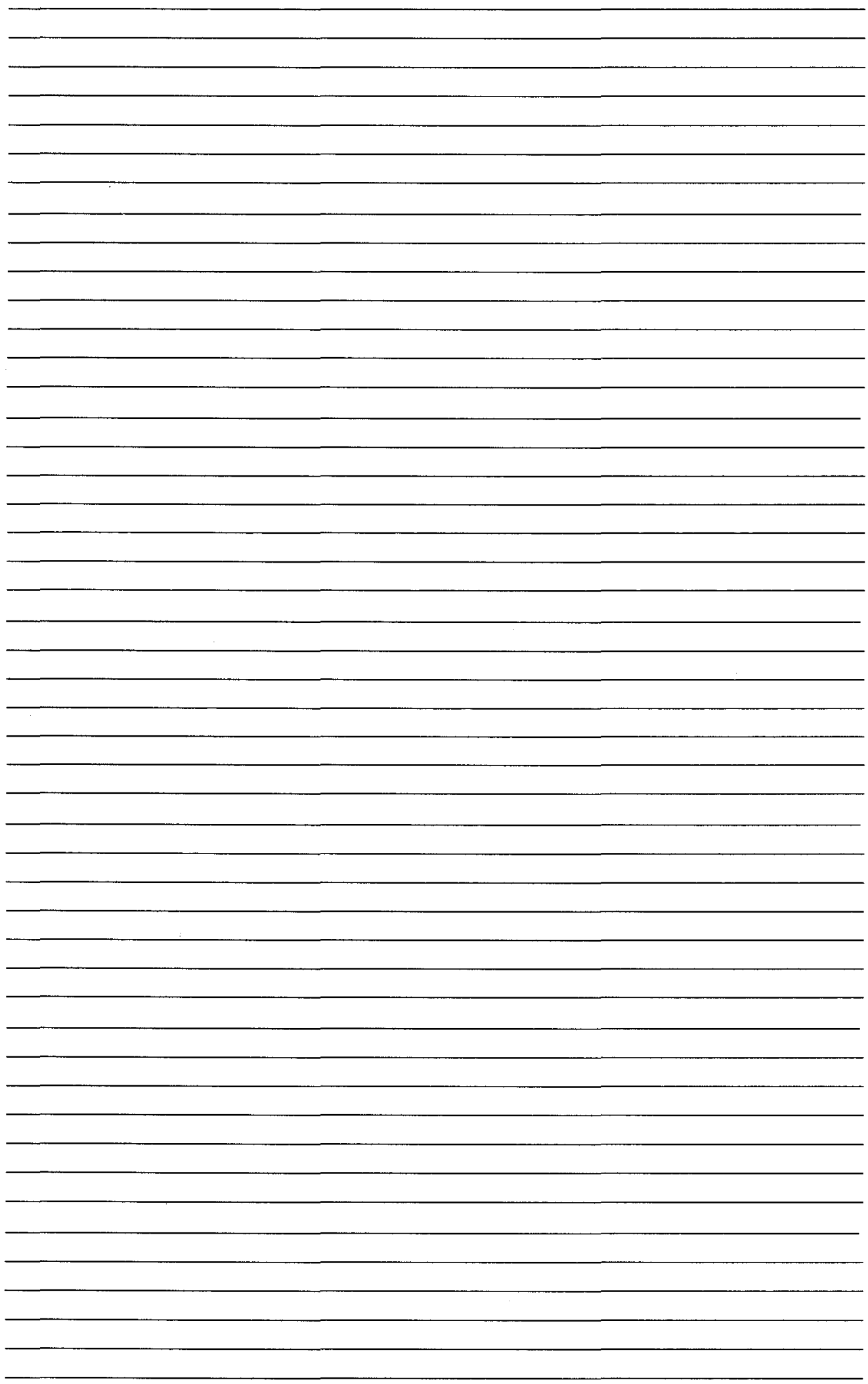

